\title{
Cytomegalovirus infections in renal transplantation : study in a rat model
}

Citation for published version (APA):

Bruning, J. H. (1988). Cytomegalovirus infections in renal transplantation : study in a rat model. [Doctoral Thesis, Maastricht University]. Rijksuniversiteit Limburg. https://doi.org/10.26481/dis.19881014jb

Document status and date:

Published: 01/01/1988

DOI:

10.26481/dis.19881014jb

Document Version:

Publisher's PDF, also known as Version of record

\section{Please check the document version of this publication:}

- A submitted manuscript is the version of the article upon submission and before peer-review. There can be important differences between the submitted version and the official published version of record.

People interested in the research are advised to contact the author for the final version of the publication, or visit the DOI to the publisher's website.

- The final author version and the galley proof are versions of the publication after peer review.

- The final published version features the final layout of the paper including the volume, issue and page numbers.

Link to publication

\footnotetext{
General rights rights.

- You may freely distribute the URL identifying the publication in the public portal. please follow below link for the End User Agreement:

www.umlib.nl/taverne-license

Take down policy

If you believe that this document breaches copyright please contact us at:

repository@maastrichtuniversity.nl

providing details and we will investigate your claim.
}

Copyright and moral rights for the publications made accessible in the public portal are retained by the authors and/or other copyright owners and it is a condition of accessing publications that users recognise and abide by the legal requirements associated with these

- Users may download and print one copy of any publication from the public portal for the purpose of private study or research.

- You may not further distribute the material or use it for any profit-making activity or commercial gain

If the publication is distributed under the terms of Article $25 \mathrm{fa}$ of the Dutch Copyright Act, indicated by the "Taverne" license above, 
CYTOMEGALOVIRUS INFECTIONS IN

RENAL TRANSPLANTATION

STUDY IN A RAT MODEL 



\title{
CYTOMEGALOVIRUS INFECTIONS in
}

\section{RENAL TRANSPLANTATION}

\author{
Study in a rat model
}

\section{PROEFSCHRIFT}

ter verkrijging van de graad van doctor aan de Rijksuniversiteit Limburg te Maastricht, op gezag van de Rector Magnificus, prof.dr. F.I.M. Bonke, volgens het besluit van het College van Dekanen, in het openbaar te verdedigen op vrijdag, 14 oktober 1988 om 14.00 uur

$$
\text { door }
$$

Johan Hendrik Bruning geboren te Rantau Prapat (Indonesië) in 1954 


\section{PROMOTORES:}

Prof. Dr. C.P.A. van Boven

Prof. Dr. P.J.C. van Breda Vriesman

\section{CO-PROMOTOR:}

Mw. Dr. C.A. Bruggeman

\section{BEOORDELINGSCOMMISSIE}

Prof. Dr. F.T. Bosman, voorzitter

Prof. Dr. J.B. Wilterdink

Prof. Dr. T.H. The

Prof. Dr. G.A. Blijham

Prof. Dr. J.P.M. Geraedts

Het onderzoek werd uitgevoerd in een samenwerkingsverband tussen de vakgroepen Immunologie en Medische Microbiologie en werd gesubsidieerd door de Nierstichting Nederland (NSN; C83-99).

In de drukkosten van het proefschrift werd bijgedragen door de Nierstichting Nederland, Wellcome Nederland B.V., en Sandoz B.V.

Omslag: Pathologische effecten van een Cytomegalovirus infectie in een humane nier (H.E.). 
Ter nagedachtenis aan mijn grootouders van Beek-Groen 



\section{Dankwoord}

Het onderzoek van dit proefschrift werd mogelijk gemaakt door een subsidie van de Nierstichting Nederland en werd uitgevoerd in een nauwe samenwerking tussen de vakgroepen Immunologie en Medische Microbiologie van de Rijksuniversiteit Limburg. Daarnaast werd een wezenlijke bijdrage geleverd door de vakgroep Pathologie en de Centrale Proefdiervoorziening.

Op de eerste plaats ben ik mijn co-promotor Cathrien Bruggeman zeer erkentelijk. Niet alleen haar centrale rol als "werkbaas", maar zeker toch ook de vriendschapsrelatie was voor mij een grote stimulans. Ondanks de vele "ups en downs" in deze relatie en in het onderzoek, was het toch haar stimulerende houding die uiteindelijk de doorslag gaf en tot dit resultaat heeft geleid. Mijn promotor Prof. dr. P.J.C. van Breda Vriesman wekte mijn interesse voor wetenschappelijk onderzoek tijdens mijn jaren als student-assistent op de afdeling Immunologie. Onze relatie, welke alle kenmerken droeg van een vader en een in karakter teveel op hem gelijkende zoon, leidde uiteindelijk tot mijn belangstelling voor medisch-wetenschappelijk onderzoek. Tijdens dit promotieonderzoek was het met name zijn enthousiasme en zijn afdeling welke het dierexperimenteel werk mogelijk maakten.

Prof. dr. C.P.A. van Boven, mijn "eerste" promotor, was door met name zijn gave om kernachtig gecompliceerde verbanden simpel samen te vatten, eerst verantwoordelijke voor het behouden van de rode draad in dit onderzoek. Mede door zijn toedoen is mijn grote interesse in de Medische Microbiologie gewekt.

Prof. dr. F.T. Bosman, hoewel niet rechtstreeks betrokken bij het onderzoek, heeft mij veel morele steun gegeven door mijn vorderingen nauwlettend te volgen en altijd blijk van interesse te tonen. Daarnaast heeft hij ook een belangrijke bijdrage geleverd aan de beoordeling van de histologische preparaten en stelde hij zijn laboratoriumfaciliteiten ter beschikking voor het maken van deze preparaten.

Hoewel niet vermeld in dit proefschrift werd veel tijd en moeite gestoken in ultrastructureel onderzoek van nierpreparaten. Dit gebeurde op het electronenmicroscopisch laboratorium onder leiding van Dr. P. Frederik. Hem en zijn medewerkers ben ik daarvoor veel dank verschuldigd.

De nier- en harttransplantaties werden met uiterste zorg verricht door Ilse Heuts en Jeanette Cornelissen. Daarbij is de coördinerende rol van Wineke Vlek van onschatbare waarde gebleken. Ook Olav Schreurs ben ik erkentelijk voor het verrichten van veel routinebepalingen. 
viii

Henk van Rie ben ik dankbaar woor de begeleiding bij mijn eerste stappen in de histologische en immunohistochemische technieken en zijn morele steun gedurende het hele onderzoek.

Veel dank ben ik ook verschuldigd aan Vivian Heijnen welke met ongelooflijke inzet als een duizendpoot enorm veel werk werrichtte. Zij bleek letterlijk Gveral inzetbaar en bleef daarbij, ondanks het opofferen van veel vrije tijd, altijd even enthousiast.

Gert Grauls en Wiel Debie zijn onmisbaar geweest bij de virologische diagnostiek en de weefselkweek. Als centrale spil op de afdeling Virologie was daarbij Gert Grauls, met haar enorme arbeidsinzet, immer opgewekte humeur en encyclopedisch geheugen, van onschatbare waarde.

Van doorslaggevende betekenis voor het histopathologische onderzoek is de produktie van muis-monoclonalen geweest; waarvoor Wiel Debie in eerste plaats verantwoordelijk is geweest.

Henk Meijer en Peter Dormans ben ik zeer erkentelijk voor hun aandeel in de moleculair-biologische aspecten in dit onderzoek. Wil Mullers dank ik voor met name zijn hulp in de grafische weergave van de onderzoeksresultaten. Voor hun aandeel in het verzorgen van de manuscripten ben ik Fia Claus, Ilse Gronenschild, Lilian Kreusch en Francien Teng veel dank verschuldigd. Dr. Davies dank ilk voor de nauwgezette taalkundige correcties van het manuscript.

Tot slot wil ik allen danken welke ik niet met name heb genoemd maar wel een bijdrage hebben geleverd aan dit proefschrift. 


\section{TABLE OF CONTENTS}

I Introduction 1

1 Introduction 1

2 Aim of the present study 2

3 Outline of the study 2

II Cytomegalovirus infection in renal transplantation; an overview 5

1 Introduction 6

2 Epidemiology of CMV infections 6

3 Epidemiology of CMV infections in renal transplant recipients and candidates for renal transplantation 10

4 Factors that may contribute to the development of CMV infections $\quad 12$

$5 \mathrm{CMV}$ disease in renal transplant recipients 18

$6 \mathrm{CMV}$ infections and renal transplant function and survival 21

7 Some explanatory models for the association between CMV infection and diminished renal allograft survival 22

8 Conclusions 26

III Characterization of the virus as a rat cytomegalovirus and determination of its genomic structure : 35

1 History of viral classification 36

2 Isolation and characterization of rat CMV 38

a. Isolation of RCMV 38

b. The virus particle 40

c. General structure of the RCMV genome 40

d. Replication in vitro 41

e. Biological aspects 42

3 Virus related proteins in infected cells. 45

a. Introduction 45

b. The structural proteins of the virion 45

c. The virus induced proteins that appear in the course of in vitro infection in REF 46

d. Comparison of structure of RCMV with cytomegaloviruses of other species 
IV The development and characterization of monoclonal antibodies against rat cytomegalovirus-induced antigens
A Summary
B Introduction
C Materials and methods
D Results
E Discussion

NATURAL HISTORY OF RCMV INFECTIONS

$\mathrm{V}$ Natural history of rat cytomegalovirus infection: an immunohistochemical study
A Summary
B Introduction
C Materials and methods
71
D Results
73
E Discussion

VI Presence of cytomegalovirus in brown fat; study in a rat model

TRANSFER OF RCMV INFECTIONS

VII Passive transfer of cytomegalovirus by cardiac and renal organ transplants in a rat model

A Summary $\quad 92$

B Introduction $\quad 92$

C Materials and methods $\quad 93$

D Results $\quad 94$

E Discussion $\quad \ldots 9$

VIII The role of transfusion of blood, blood derivatives and renal cells in the transfer of cytomegalovirus infections 103
A Summary
B Introduction
C Materials and methods
D Results
E Discussion 
IX Enhancement of reactivation of latent rat cytomegalovirus (RCMV) by combination of immunosuppression and administration of allogeneic immunocompetent cells
A Summary
B Introduction
C Materials and methods
D Results
E Discussion

$X$ The transfer of CMV infection in rats by latent infected renal allografts and the role of various immunosuppressive regimens on virus reactivation

EFFECT OF RCMV INFECTIONS ON RENAL ALLOGRAFTS

XI The effect of cytomegalovirus infection on renal allograft function in a rat model
A Summary
B Introduction
C Materials and methods
D Results
E Discussion

XII Summary and conclusions

Samenvatting

Curriculum vitae 


\section{INTRODUCTION}

Cytomegalovirus (CMV) infections are widespread among the normal population. Large scale serological investigations have revealed that approximately 60$90 \%$ of the population are infected. After primary infection CMV remains - as most Herpesviruses - in a latent state in the body. The exact mechanisms of latency and reactivation are far from completely understood, although a variety of observations indicate that an unimpaired and mature immune system, and especially that the specific immune response elicited by the virus, are essential factors in forcing the virus into a latent state and maintaining it in this condition. The majority of primary and reactivation infections do not result in clinical symptoms, although manifest disease, with serious complications such as pneumonia or hepatitis, does occur in immune-compromised individuals.

The introduction of new and effective immunosuppressive agents to control rejection made it possible to transplant tissues and organs for the treatment of various diseases. The use of immunosuppressive agents, however, does create a patient population with impaired immunity and it is in these patients that CMV shows its full potential for producing disease. Although primary CMV infections can occur in seronegative recipients of a renal graft from a seronegative donor, it is reactivation of latent virus from the recipient or from the donated allograft that accounts for the majority of the infections. Reactivation infections in most cases originate from the donated kidney allograft, and only infrequently from blood transfusions administered at the time of transplantation. In the latter case it is assumed that the CMV infection is transmitted by leucocytes, because primary infection following transfusions with leucocyte-free blood and blood derivatives is rare. Primary or reactivation-infection in kidney transplant recipients frequently necessitates decreasing the immunosuppressive therapy to prevent serious infective complications which might lead to a fatal outcome. In these patients a deterioration of kidney graft function and a flare up of graft rejection is often noticed. An important and unsolved question is whether this is a direct effect of CMV on the kidney graft or is the consequence of diminished immunosuppressive therapy. 
The data suggesting a localisation of the virus in the kidney are predominantly based upon case histories from severely immuno-suppressed patients with generalized CMV-infection. Few systematic studies on the presence of CMV in donor kidneys are, however, available and the results are contradictory.

The objective of the experiments presented in this thesis was to study the question mentioned above in a defined experimental animal model (vide infra). The advantage in using an animal model is obvious: the factors that cause CMV infection and disease in the human situation in a complex and interdependant way can be studied separately under controlled conditions in the animal model. The availability of techniques for kidney transplantation in rats and the discovery of a rat cytomegalovirus made such an experimental approach to the question possible.

\section{I.2 AIM OF THE PRESENT STUDY}

The aim of the study was twofold:

- firstly to explore the localisation of the (latent) virus within organ grafts;

- secondly to address the question of the effect of CMV infection on renal allograft survival.

\section{I.3 OUTLINE OF THE STUDY}

In Chapter II a brief review is presented of the current literature concerning

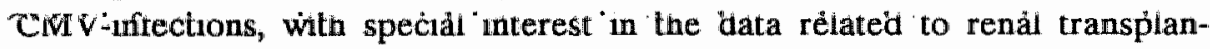
tation, and some explanatory models are summarised of how CMV infections might have an influence on renal allograft survival.

Furthermore the isolation and characterization of a rat strain of cytomegalovirus is described, preceded by a short review of the history of classification of Herpesviridae and Cytomegaloviruses (Chapter III).

A battery of mouse monoclonal antibodies was produced against most of the structural proteins of the rat cytomegalovirus (RCMV), as discussed in Chapter IV. The natural history of RCMV-infection was studied in unmodified immunocompetent, as well as in immunocompromized rats with the aid of these monoclonal antibodies. This is discussed in Chapters V and VI.

In Chapters VII and VIII the modes of transmission of RCMV infection are investigated. The contribution of transfusions of blood or blood derivatives, and of complete viable organ transplants as well as cell suspensions obtained 
from these organs, is studied in relation to the transfer of RCMV-infection. The factors influencing reactivation of RCMV in latently infected rats or in renal allografts, (and, thus, the infection transfer rate) is studied in Chapters IX and $X$.

The effects of acute or reactivation RCMV infections in either unmodified or immunosuppressed rats on acute or chronic rejection episodes is studied in some well-defined renal transplantation models, as discussed in Chapter XI. In Chapter XII the main conclusions of the study are summarized and suggestions are made for further investigation. 
CHAPTER II

CMV INFECTIONS

AND RENAL TRANSPLANTATION;

AN OVERVIEW 


\section{II.1 INTRODUCTION}

This chapter is a brief literature study on the epidemiology of cytomegalovirus (CMV) infections in man, and in particular, in recipients of renal allografts.

It is based on clinical reports from 1969 onwards, as presented in the reviews of Hamilton (1), Ho (2), Glenn (3), and Lopez (4). These studies are summarised in tables III-VIII. In the more recent past (1982-1988) some large epidemiological studies have been published (5-9) on this matter, but since these reports did not contain all the data necessary to include them in tables III-VIII, they have been omitted. The main conclusions in these reports, however, did not differ greatly from those presented in earlier publications as included in tables III-VIII.

\section{II.2 EPIDEMIOLOGY OF CMV INFECTIONS}

Infection with CMV leads to the production of antiviral antibodies. The number of individuals with anti-CMV antibodies (seropositives) in a population provides an estimate of the prevalence of CMV infections in that population.

When the prevalence of CMV infections, on the basis of complement fixing antibody (CFA)-titres, is estimated, large variations in seropositivity are noted between various populations. Data from Krech et al. $(10,11)$, Stern and Elek (12), Luby and Shasby (13) indicate that variables such as age, sex, socioeconomic status and geographical localisation should be regarded when antibody status in different (patient) groups is compared.

The impact of the variables age, geographical localisation and socio-economic status is summarised in tables I and II, and figure 1, respectively.

Prevalence of seropositivity gradually increases with age to a maximum of $54-72 \%$ in adults in the Western countries, and $100 \%$ in adults in Asia and Africa.

In general, adult females have a uniformly higher prevalence of anti CMVantibodies (13) than men.

As for socio-economic status, it appears that the lower the socio-economic status, the higher the chance of infection at an early age. In other words, the gradual rise in prevalence of seropositivity progresses faster in the lower socio-economic groups, while the peak of prevalence of seropositives in adults is somewhat higher in these groups when compared to groups with higher socio-economic status $(10,12)$ (Fig. 1). 
In the determination of whether or not an individual has been infected with CMV on basis of the anti CMV antibody status, some uncertainties and potential errors should be accounted for:

As stated before, and shown in Tables $I$ and II, most data concerning prevalence of CMV infections are based upon complement fixing antibodies (CFA). It still remains to be determined if the asumption these investigations are based on, namely that infection with $\mathrm{CMV}$ will invariably result in lifelong measurable titres of CFA, is correct.

- Firstly, it is not known whether infection with CMV, although inducing humoral immunity, necessarily leads to induction of CFA in all instances; possibly in some cases only non-complement fixing, neutralising antibodies, or antibodies active in antibody-dependent cellular cytotoxicity (ADCC), or opsonisation are elicited, leading to an erratic low incidence when only CFA are being measured. Moreover, antibody levels have been reported to show considerable variations in the course of time when measured in the same individuals (18). It is not known whether antibody levels in normal healthy adults may occasionally become so low that, with routine techniques, they are no longer measurable.

- Secondly, it should be kept in mind that immunosuppression may have its impact on the serological status as well $(2,15-17)$, and serological tests may be falsely negative in immunosuppressed or severely ill patients. In that case culture techniques should always be included in the diagnostic procedures.

- Finally, apart from the different types of antibodies that are measured by the various tests available, the sensitivity of each of these tests in itself may vary considerably between one and another. In relatively few reports concerning epidemiological studies on CMV infection have various serological tests been employed at the same time and compared. Although the results achieved with two or three serological assays frequently agree with each other, a relatively high incidence (14-20\%) of discrepancies is observed and this may lead to difficulties in defining seropositivity $(5,14)$. In a large epidemiological study concerning the impact of CMV infection on renal transplantation by Rubin et al. 1985 (5) it was found that the indirect immunofluorescence assay (IFA) yielded information consistently different from that of the complement fixation test (CFT) and the indirect haemagglutination assay (IHA). When IFA was used, a relatively large group of patients was found to be seropositive before transplantation (14\%) whereas they were seronegative when CFT or IHA were employed as standard screening assays. 
In conclusion, cytomegaloviruses are widely distributed throughout the world. Typically the majority of infections caused by $\mathrm{CMV}$ are clinically inapparent. However, clinical manifestations of disease may appear, even in normal healthy individuals (19-23).

Congenital and perinatal infections are the most important in terms of frequency and consequences (28-34). Mononucleosis, post-perfusion syndrome and other clinically definable diseases due to CMV are interesting (but infrequent) causes of morbidity in the normal host (19-27).

The prevalence of seropositivity for CMV in chronically immuno- suppressed individuals, e.g. patients with chronic renal failure, and renal transplant recipients, differs from that of the general population.

Infections, and disease related to these infections, frequently form a serious problem in the immunocompromised host, as they do in recipients of renal allografts. In the following sections these issues are discussed further.

Fig. 1: Prevalence of anti CMV antibodies (IFA) and rate of increase in association with socio-economic status “.

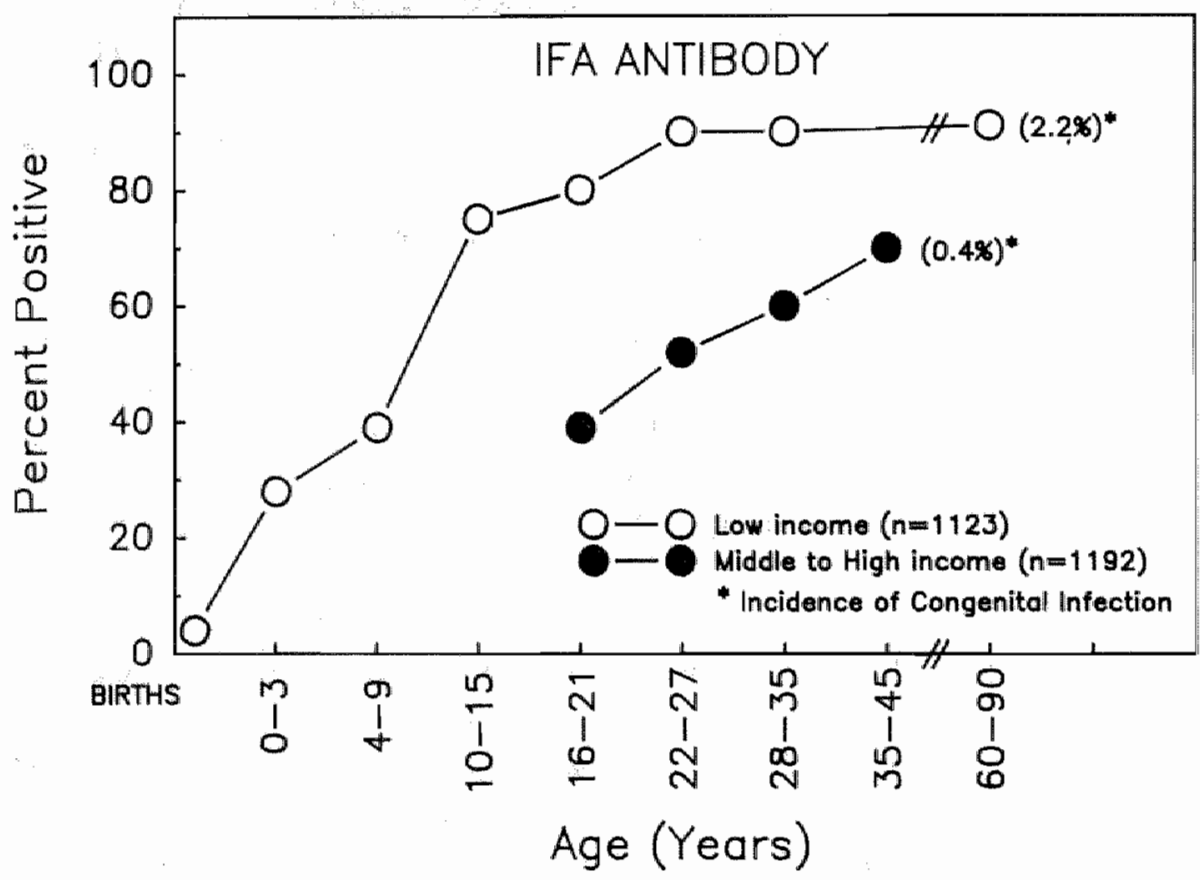

Effect of age and socio-economic status on the acquisition of CMV infection shown by the presence of antibodies in the indirect fluorescent assay (IFA). (Alford, C.A., Stagno, S., Pass, R.F.: Natural history of perinatal cytomegalowiral infection. In: Perinatal infections. Ciba Foundation Symposium, Amsterdam, Excerpta Medica, 1980). 
Tablle I: Age dependent prevalence of anti CMV complement-fixing antibodies in London*

\begin{tabular}{lccc}
\hline $\begin{array}{l}\text { Age group } \\
\text { (Years) }\end{array}$ & No. positive/No. tested & $\begin{array}{l}\text { Percent } \\
\text { positive }\end{array}$ & $\begin{array}{c}\text { Rate of } \\
\text { increase } \\
\text { (\%o/year) }\end{array}$ \\
\hline $0-0.5$ & $3 / 9$ & 33 & \\
$0.5-5$ & $4 / 93$ & 4 & 2.1 \\
$5-10$ & $15 / 97$ & 15 & 0.8 \\
$10-15$ & $54 / 257$ & 21 & 2.0 \\
$15-25$ & $47 / 130$ & 36 & 1.8 \\
$25-35$ & $62 / 114$ & 54 & 0.0 \\
$35-75$ & $46 / 85$ & 54 & \\
\hline
\end{tabular}

- Data from Stern and Elek, 1965 (12).

Table II: Prevalence of anti CMV complement-fixing antibodies in blood donors from six continents.

\begin{tabular}{llc}
\hline City & Country & $\begin{array}{c}\text { Percentage with } \\
\text { CF antibodies }\end{array}$ \\
\hline Lyon & France & 40 \\
Freiburg & West Germany & 42 \\
St Gallen & Switzerland & 45 \\
Albany & USA & 45 \\
Melbourne & Australia & 54 \\
Stockholm & Sweden & 60 \\
Manchester & UK & $6 \mathbb{1}$ \\
Houston & USA & 79 \\
Buenos Aires & Argentina & 81 \\
Hong Kong & & 94 \\
Sendai & Japan & 96 \\
Entebbe & Uganda & 100 \\
Manila & Philippines & 100 \\
Chandigarh & India & 100 \\
\hline
\end{tabular}

Modified from Krech, 1973 (10) 


\section{II.3 EPIDEMOLOGY OP CMV INFECTIONS IN RENAL TRANSPLANT RECIPIENTS AND CANDIDATES POR RENAL TRANSPLANTATION}

From the previous paragraphs it will have become clear that, although CMV is almost ubiquitous in the general population, there are still large variations in seropositivity for CMV in various subgroups.

Clearly, candidates for renal transplantation form a subgroup within the general population in which the incidence of seropositivity for CMV not only is influenced by the variables mentioned, but is further affected by many other risk factors for acquiring CMV infections. This will be discussed in $\$ 4$. In this paragraph the prevalence of CMV-seropositivity and active infections (i.e. four-fold titre rise and/or positive virus culture) will be presented of the group of candidates for renal transplantation, and compared with the group of recipients of renal allografts. These data are based on at least 20 separate reports as summarised by Hamilton et al. (1) and Rubin et al. (5), and shown in Table III.

In candidates for renal transplantation, i.e. patients with chronic renal failure and on dialysis, the prevalence of CMV antibodies is 54-95\% (35-37) and thus within the range of renal allograft recipients one year after transplantation (59-92\%; mean $82 \%)$. This is somewhat higher than the prevalence in the general population $(65 \%)$ of the same age-range (1).

No explanation is available for the generally higher values reported for chronic renal failure patients compared with the candidates for renal transplantation as noted in table III (31-79\%; mean 65\%). Probably other variables such as duration of renal failure, time on dialysis, immunosuppressive therapy, etc. should be accounted for to compare the two groups.

However, the incidence of active infection is as high as $76 \%$ (range 57-89\%) in the renal transplant recipients (table III), whereas in the chronic renal failure group it varies between $1-13 \%(35,38-40)$.

Apparently the transplantation procedure has an enhancing effect on detectable viral replication, reflected by seroconversion and/or viraemia and viruria. This will be discussed further in $\$ 4$. Seroconversion, however, or the findings of viraemia and/or viruria is not necessarily accompanied by CMV-related disease as will be discussed in the following paragraphs 4 and 5 . 


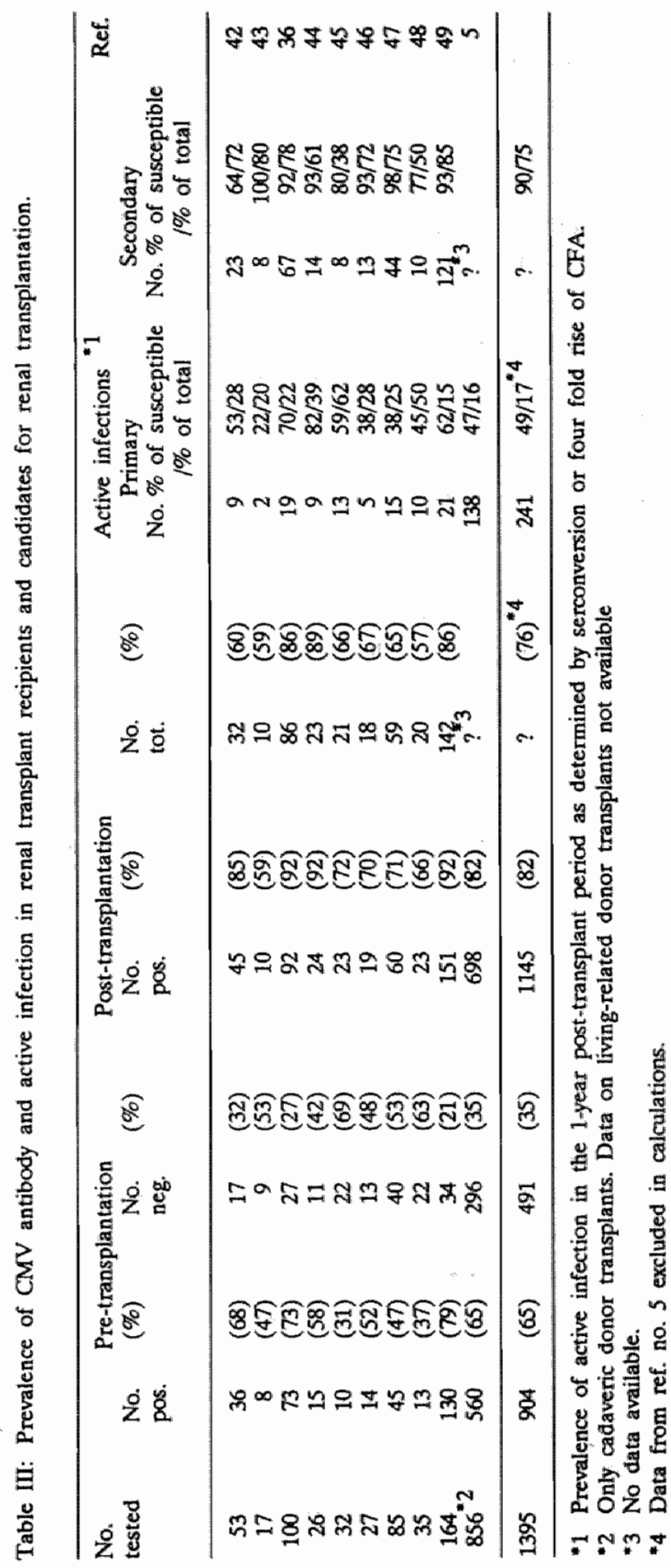


II.4 FACTORS THAT MAY CONTRIBUTE TO THE DEVELOPMENT OF CMV INFECTIONS IN RENAL TRANSPLANT RECIPIENTS AND CANDIDATES FOR RENAL TRANSPLANTATION

As was pointed out in previous sections, CMV infections are widely distributed throughout the general population; in fact few individuals escape infection during their lifetime. The vast majority of the naturally occurring primary CMV infections are clinically asymptomatic; a small proportion of adults (1$5 \%)$ may have clinical symptoms (19-27), which include hepatitis $(19,20)$, a mononucleosis-like syndrome (27), and pneumonia (22).

More severe disease, with prolonged fever, leucopenia, hepatitis, pneumonia, or even myocarditis and encephalitis, may occur in immunocompromised hosts, including neonates(28-34,50-52), and iatrogenically immunosuppressed hosts (34-37,53-55) after primary infection, or (in the iatrogenically immunosuppressed patients) after reactivation of a latent infection.

The factors influencing the occurrence of primary and reactivation infection in recipients of renal allografts is dealt with in this section.

\section{Risk of CMV infection associated with blood transfusion}

The possibility that blood transfusions could transmit CMV was considered as early as 1951 (56).

Furthermore, CMV was linked to the post perfusion syndrome seen in open heart surgery patients undergoing extracorporeal circulation (57-60). Since the mid 1960's numerous prospective studies on transfusion recipients have documented the frequent occurrence of post transfusion CMV infections. These studies are summarised in Table IV. The average infection rate was $13 \%$ (range 3-67\%) for the 1845 patients studied. Primary infections were more frequent (19\%) than secondary or reactivation infections (9\%). Clinically apparent infections were found only in $1.6 \%$ (i.e. 22 patients out of 1410 ). Disease was practically restricted to primary infections, except for one study (63). From 1971 to 1982 only five symptomatic infections have been reported in these studies. Other conclusions that can be drawn from the data represented in table IV are: $1^{\text {st }}$ that the infection rate correlates with the amount and frequency of blood administrations; the risk of acquiring infection rises significantly when five or more units of blood have been administered; $2^{\text {nd }}$ that pre-transfusion CMV-antibody in the recipient has a protective effect against transfusion-induced CMV infection. In renal allograft transplantation, blood transfusions are almost invariably administered. Although CMV infection in 
these patients is mostly obtained from the renal allograft, as will be discussed in the next section, blood transfusions may still be responsible for a significant proportion of the infections. In the multicentre study of Rubin $e t$ al. (5), in which 1245 renal allograft recipients were studied prospectively, $20 \%$ of seronegative recipients of seronegative renal grafts mounted antibodies to CMV. All these patients received transfusions of blood products containing viable leucocytes post transplantation. However, in 79 of the seronegative/seronegative pairs that not received leucocyte-containing transfusions not a single instance of seroconversion could be documented. This clearly demonstrates the role of leucocytes in the transfer of CMV infections, and therefore emphasizes the necessity to use leucocyte-depleted blood or frozen blood when transfusions are to be given in patients at risk for CMV disease.

\section{Risk of CMV infection associated with transmission via the donated organ}

When donors of renal transplants, as a group, are considered representative for the general population the percentage of seropositives is about 60 . Since the virus (after infection) probably remains lifelong within the body of its host in a latent form (Chapter III), where it can be reactivated by various factors (vide infra), it will become clear that renal transplants obtained from seropositive donors are potentially important vectors for viral transmission.

At least three groups reported, nearly simultaneously, serological evidence implicating the donated kidney as a potential source of $\mathrm{CMV}(45,70,71)$. Ho et al. (45) prospectively studied a group of 32 transplant recipients and their donor partners. Whereas $16(80 \%)$ of 20 recipients of kidneys from seropositive donors became infected, only five (42\%) of 12 recipients of kidneys from seronegative donors had post-transplantation CMV infection. Very similar results were reported independently by others (5,42-44,70-73). Among seronegative patients, the rate of post-transplantation $\mathrm{CMV}$ infection can be substantially reduced by transplanting kidneys only from donors who are themselves seronegative $(45,70,73)$, and even completely prevented when also only blood transfusions from seronegative donors are administered $(5,74)$. This is illustrated in Tables $\mathrm{Va}$ and $\mathrm{b}$.

In recent years increasing data indicate that also in seropositive recipients of a seropositive renal allograft, the source of the virus in active CMV infections is frequently, or even mostly, the donor kidney (75-77). These data were obtained by the use of highly sophisticated molecular biological techniques such as restriction enzyme analysis. 


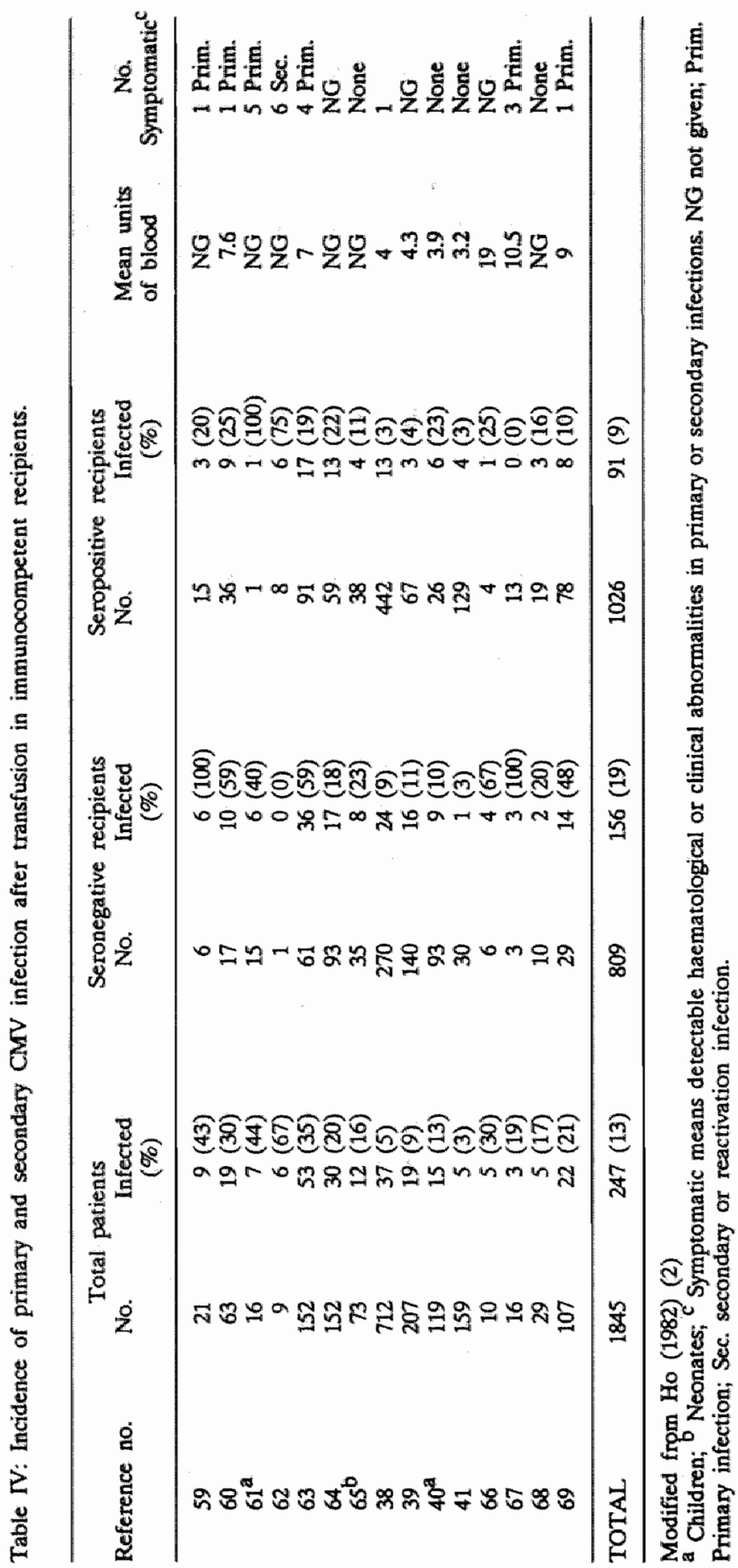


From these studies it becomes clear that probably many CMV infections (and their clinical implications) in renal allograft recipients can be avoided when only renal grafts from seronegative donors are employed.

This, however, will not be practicable, since it would greatly reduce the number of donor grafts available and these are already in short supply.

Table Va: Influence of donor CMV serology on incidence of infection in seronegative recipients.

\begin{tabular}{lccc}
\hline & \multicolumn{3}{c}{ Recipient } \\
\cline { 2 - 4 } $\begin{array}{l}\text { Status of } \\
\text { kidney donor }\end{array}$ & $\begin{array}{l}\text { No. of } \\
\text { patients }\end{array}$ & $\begin{array}{l}\text { No. with } \\
\text { infection }\end{array}$ & $\begin{array}{l}\text { Percentage } \\
\text { becoming infected }\end{array}$ \\
\hline $\begin{array}{l}\text { Seropositive } \\
\text { Seronegative }\end{array}$ & 81 & 62 & 77 \\
\hline
\end{tabular}

Data are pooled from $45,46,73,74,78$.

Table Vb: Influence of donor and recipient pre-transplant CMV serology on incidence of infection.

\begin{tabular}{ccc}
\hline CMV antibody status of donor & CMV antibody status of recipient \\
\cline { 2 - 3 } & + & - \\
\hline+ & $\sim 90 \%$ & $-75 \%$ \\
- & $\sim 90 \%$ & 0 \\
\hline
\end{tabular}

adapted from Glenn et at. (3)

\section{Factors leading to reactivation of latent $C M V$}

Results of animal and human studies indicate that cellular immune mechanisms are particularly important in resistance to CMV (79-84). Immunosuppressive drugs given to mice prevent development of (or suppress) cell-me-

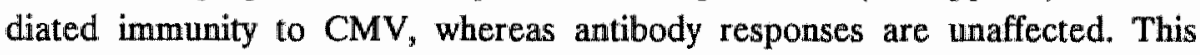
pattern correlates well with the situation in human transplant recipients who, as a group, become deficient in cellular responses to CMV antigens whereas antibody responses seem to be unaffected $(79,82)$. The period of deficient cellular responses corresponds to the period of greatest risk of CMV infections among cardiac recipients (83-84). The same is likely to be the case in renal transplant recipients $(80,81,82)$. 


\section{Corticosteroids, azathioprine, cyclophosphamide}

A group in which the effect of immunosuppressive therapy sec on the occurrence of active CMV infections was studied has been presented by Dowling et al. (85). They studied a group of patients with connective tissue disease who were being immunosuppressed with either corticosteroids, azathioprine or cyclophosphamide. The advantage of studying this group was that these patients were not undergoing a transplant operation, receiving blood or experiencing allo-immune responses. Although plausible, there were no indications that their underlying disease contributed to their susceptibility to CMV infections. The prevalence of seropositivity before starting therapy was not remarkably different from that reported for chronic renal failure or transplant patients ( $65 \%$ and $82 \%$, respectively). None of the patients given corticosteroids or not treated at all developed active infection; no virus could be isolated from their buffy coats or urine during a 12-week follow up. In a prospective study on 14 patients on cyclophosphamide or azathioprine, from the time of initiation of therapy, five out of nine (56\%) who were seropositive developed viruria, compared to one out of five seronegative patients $(20 \%)$. Before initiation of therapy no virus could be demonstrated in either buffy coats or urine of the 86 patients studied. As is the case with renal transplantation, infection occurred between 6 and 12 weeks after drug therapy was started. The rate of infection was lower than in the renal transplant group ( $\$ 3$ ), probably because the rheumatology patients were not exposed to a number of other risk factors. It appeared thus that steroids did not play a large role in increasing susceptibility to CMV infections, and that azathioprine and cyclophosphamide had enhancing effects on the occurrence of active CMV infections $(5,6,9)$. Other investigators, however, have suggested that steroids do have potentiating effects on the ability of CMV to infect or multiply (86).

\section{Cyclosporin $A$}

Contrary to the reports with azathioprine and cyclophosphamide, CMV disease might be less frequently seen in cyclosporin-A treated patients (6-9). In fact, since the introduction and almost uniform use of Cyclosporin $A$ to control graft rejection in renal transplant recipients, CMV infections (and, more clearly, CMV-related morbidity) have shown a sharp decline (6-9,55,87-88).

\section{Anti lymphocyte serum}

Several centres have reported the adverse effect of antilymphocyte preparations on several aspects of reactivation of $\mathrm{CMV}$, including a higher incidence 
of viraemia and CMV-related illness and prolongation of impaired cell-mediated immune responses to CMV (2,55,89-90).

\section{Anaesthesia and surgery}

In addition, anaesthesia and surgery in themselves can alter immune responses, leading to higher susceptibility to CMV infections (91). Among 12 healthy individual kidney donors lymphocyte counts fell, DTH-skin reactions were depressed, and responses to mitogen stimulation and reactivity in a mixed lymphocyte assay were reduced immediately after induction of anesthesia and continued to diminish during and after surgery. This indicates that merely the transplantation procedure in itself can alter the immune response and might lead to reactivation of latent CMV present either within the donated kidney or in the recipient.

\section{Allo-immune responses}

There is good experimental evidence that host versus graft (HvG) as well as graft versus host $(\mathrm{GvH})$ reactions will reactivate $\mathrm{CMV}$ infection in mice (9293). There are no definite data in humans on the role of $\mathrm{HvG}$, but it is suspected: Pass et al. (71) reported that 60 days after renal transplantation $76 \%$ (16 out of 21) of patients who received cadaveric kidneys - but only $33 \%$ (6 out of 19) who received kidneys from living related donors - became infected with $\mathrm{CMV}$ (i.e. productive infection of either primary or secondary origin). This difference was thought to be due to greater HvG reaction towards cadaveric transplants. Others have confirmed this finding and found a correlation between more severe CMV disease and cadaveric kidney transplants as well $(2,5,14)$.

In a report on bone marrow transplantation by Meyers et al. (94-95) it was shown that $\mathrm{GvH}$ reactions play a definite independent role in increasing liability to CMV infection. Only $12 \%$ of patients who did not develop GvH became infected ( 2 out of 17 ) while $70 \%$ ( 26 out of 37 ) who developed GvH disease became infected (i.e. fourfold titre rise and/or positive culture). In addition, the GvH reaction increased the morbidity or clinical severity of the CMV infection, primarily manifested by interstitial pneumonia. This observation was confirmed in other studies (96-97).

With renal transplantation the role of $\mathrm{GvH}$ is subject of debate. The study as presented in this thesis will render more insight in this respect. 


\section{II.5 CYTOMEGALOVIRUS DISEASE IN RENAL TRANSPLANT RECIPIENTS}

As was stated before, seroconversion and/or positive virus cultures are not per se accompanied by disease. Criteria for CMV related disease are somewhat variable and largely author-determined, but in general include fever, leucopenia, pneumonia, hepatitis and any combination of these $(36,42-49)$, together with seroconversion and/or positive virus cultures. Graft rejection is not included as an indicator of CMV-disease. The data presented in this paragraph (Table VI) are based on the same reports as mentioned in a previous paragraph (Table III; $\$ 3$ ), and consequently concerned the same patient-groups.

The risk of disease from primary CMV infection is $40-100 \%$ with a mean overall risk of disease of $66 \%$, whereas the risk of disease from secondary CMV infection ranges from $0-86 \%$, with a mean overall risk of $27 \%$ (Table VI). These differences were shown to be significant $(1)(p<0.01)$ when tested by the MantelHaenzel test (98), and the standardized relative risk is 9.3, indicating a 9-fold greater risk of disease with primary infection than with secondary infection. As was discussed before $(\$ 2)$, the type of serological assay employed in order to discriminate between seropositives and seronegatives may have important effects on the outcome of statistical correlations between a specific risk factor and the serological status, as illustrated in Table IX. In the study of Peterson et al. (14) the use of the combination of IFA and CF tests resulted in a considerable shift of individuals considered seronegative by $C F$ test into the seropositive group. The statistical positive correlation found between the serological status of the donor and the incidence of CMV disease in the recipients (when only the CF test was used) disappeared when both CFA and IFA were employed to define the serological status.

Possibly this is only due to the small number of donor/recipient pairs in the seronegative donor group, and the observed correlation will regain statistical significance when larger numbers are studied, but this effect certainly should be kept in mind when statistical calculations are made with data obtained from various centres.

An interesting but puzzling observation was made by Smiley et al. (76) who studied the role of pre-transplantant immunity in protection against CMV disease following renal transplantation in 1153 donor/recipient pairs. They found that in recipients of kidneys from seropositive donors immunity offered significant protection from $\mathrm{CMV}$ disease, reducing its incidence from $61 \%$ to $24 \%(\mathrm{p}<0.01)$. However, among recipients of kidneys from seronegative donors, pre-transplant immunity conferred a significant risk of CMV disease; immune patients had a $20 \%$ incidence of CMV disease compare with $2 \%$ in nonimmune patients $(\mathrm{p}<0.02)$. Another factor of considerable influence on the incidence and severity of CMV disease is the type and degree of immunosuppression $(5,6,9,77-82)$. Finally 
the combination of risk factors mentioned before may have its own particular effects. For instance, in a large multicentre study of Rubin et al. (5) in which immunosuppression of various types and combinations, together with the serological status of the recipient, were correlated with the incidence and severity of CMV disease. The following data were found. Those at risk for CMV reactivation infection (seropositives) had an increased risk for mortality, whereas those with primary CMV infection (seronegative beforehand) had an increased rate of allograft survival with poor function (creatinine $>3 \mathrm{mg} / \mathrm{dl}$, or $265 \mu \mathrm{mol} / \mathrm{h}$ six months post-transplant).

For patients receiving antilymphocyte serum in addition to conventional doses of prednisone and azathioprine, the effects were more striking: patients with, or at risk for, primary $\mathrm{CMV}$ infection had an increased rate of patient mortality and allograft loss, both when compared with other patients receiving an antilymphocyte preparation and when compared with similar patients not receiving such treatment.

In contrast, however, antilymphocyte preparation administration was associated with an increased rate of allograft survival in patients at risk for reactivation disease. There was no discernible effect of such treatments on patients at minimal (or no) risk of CMV infection.

This phenomenon is hard to explain, but suggests an immunopathological mechanism, abolished by the administration of anti-lympocyte serum. This issue, the effect of CMV infections on renal allograft survival, will be further discussed in following sections ( $\$ 6$ and $\S 7$ ).

Some authors have defined various subgroups within the renal allograft recipients that develop CMV-related disease (102). In a prospective study of the role of CMV in renal transplant recipients Simmons et al. (102) identified two patterns of CMV infection. In both patterns, fever and leucopenia occurred within six months after transplantation. In addition, the benign form was characterised by renal biopsy evidence of rejection and brisk antibody responses to CMV. The lethal form ran a typical 4-week course, beginning with prostration, orthostatic hypotension and mild hypoxaemia, and progressing to severe pulmonary and hepatic dysfunction, muscle wasting, central nervous depression and death. Antibody responses to CMV were minimal, and renal biopsy did not show rejection despite elevation of serum creatinine. At autopsy CMV was found in almost every organ.

It seems tempting to suggest from this study that when a patient fails to mount an antibody response towards the CMV infection, a lethal syndrome develops, whereas when there is a brisk antibody response this may lead to renal allograft dysfunction and rejection (see Chapter 8 ). How clearcut this association between CMV infection and renal allograft failure is will be further discussed in $\S 6$. 


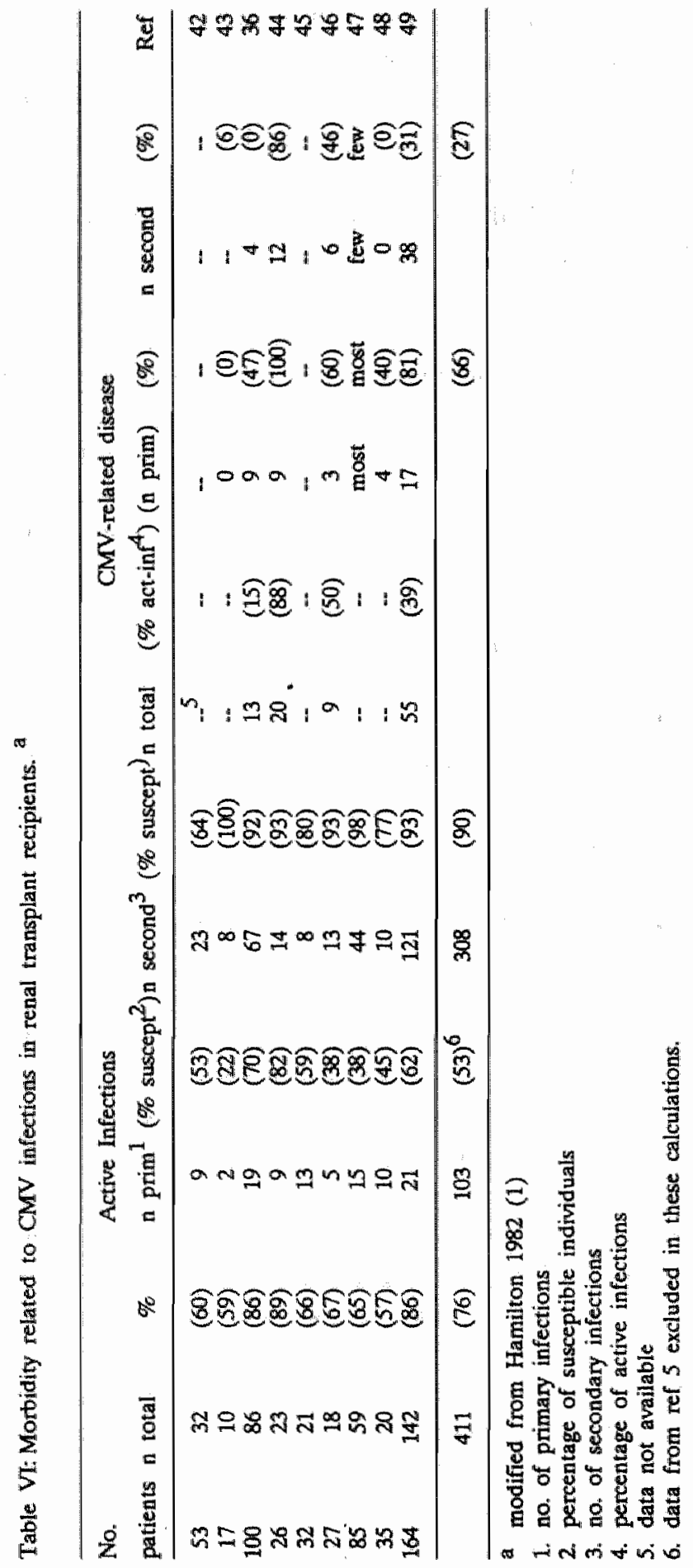


Tabie VII: Influence of donor and recipient pre-transplant CMV serology on incidence of CMV disease.

\begin{tabular}{|c|c|c|c|}
\hline \multirow{2}{*}{$\begin{array}{l}\text { Serological status of } \\
\text { donor/recipient pairs } \\
\text { By CF antibody test" }\end{array}$} & \multirow[t]{2}{*}{$\begin{array}{l}\text { Number of } \\
\text { pairs }\end{array}$} & \multicolumn{2}{|c|}{$\begin{array}{l}\text { Number (\%) of recipients } \\
\text { who developed CMV disease }\end{array}$} \\
\hline & & & \\
\hline negavive/negative & 28 & $4(14)$ & \\
\hline negative/posiitive & 16 & $3(19)$ & NS. \\
\hline positive/negative & 11 & & $\mathrm{p}^{*}<0.02$ \\
\hline positive/positive & 24 & $9(38)$ & NS. \\
\hline \multicolumn{4}{|c|}{$\begin{array}{r}\text { By } \mathrm{CF} \text { and } \mathrm{IF} \text { antibody*** } \\
\text { tests ( } 78 \text { pairs) }\end{array}$} \\
\hline negative/negative & 5 & $0(0)$ & \\
\hline \multirow[t]{2}{*}{ negative/positive } & 16 & $4(25)$ & NS. \\
\hline & & & $\mathrm{p}^{*}<0.42$ (N.S.) \\
\hline positive/negative & 12 & $4(33)$ & 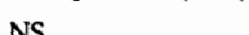 \\
\hline positive/positive & 45 & $12(27)$ & No. \\
\hline
\end{tabular}

- Based on chi-square test

* CMV CF antibody titre $<4=$ negative; $\geq 4=$ positive

*.* CMV CF antibody titre $<4$ and IF antibody titre $\leq 10=$ negative; $\mathrm{CF} \geq 4$ and/or IF $\geq 20=$ positive

\section{II.6 CMV INFECTIONS AND RENAL TRANSPLANT FUNCTION AND SURVTVAL}

The impact of active CMV infections and CMV disease on renal allograft survival was studied $(4,44,48-49,78,103-105)$ in the same patients (transplantation centres) as mentioned in Tables III and VI. The data are summarised in Table VIII.

The total number of uninfected patients with graft rejection was 50 out of $159(31 \%)$, compared to 140 out of $336(42 \%)$ with graft rejection in the infected group; a statistically significant difference $(p<0.01)$ by the MantelHaenzel test (98) with a standarised relative risk (SRR) of 1.8 .

The patients with primary infections showed an increased frequency of renal allograft rejection (54\%) which was however not significantly different from both the uninfected patients (38\%) and those with secondary infection (36\%) in comparable groups, as shown by the Mantel-Haenzel test.

These data indicate that patients infected with CMV are at greater risk of developing a renal allograft rejection as compared to uninfected patients, with possibly a major role for primo-infections, but this is not conclusive. However, the question how CMV infection influences allograft survival cannot be answered. Most CMV infections occur within 3 months after transplantation 
$(14,42,45-46,70)$. The reports on the sequence in which infection and rejection occur are not numerous; Betts et al. (70) demonstrated that infection was followed by graft rejection; other authors report that graft rejection preceded seroconversion and virus isolation $(4,103)$. Although the evidence is not convincing either way, most data suggest that allograft rejection precedes active infection with $C M V$ and may therefore be important in the predisposition to infection or in the reactivation of latent virus ( $\$ 4$; ref. 45,71).

Some authors suggest that CMV infection even resulted in a better graft survival when the infection remained asymptomatic, as compared with patients experiencing symptomatic infections, or even as compared with uninfected patients $(48,49)$.

How the CMV relates to CMV-associated disease and transplant function is a topic of debate, and it may be influenced by numerous factors, including uraemia, preexisting disease (diabetes, SLE), the immune suppressive regimen administered, serological status of donor and recipient, sentitization or tolerance to HLA antigens, HLA and non-HLA mismatch between donor and recipient, age, sex etc., etc.

In the following section some possible mechanisms by which CMV infection and diminished renal allograft survival might be related are briefly reviewed.

\section{II.7 SOME EXPLANATORY MODELS FOR THE ASSOCIATION BETWEEN} CMV INFECTION AND DIMINISHED RENAL ALLOGRAFT SURVTVAL

If there is a causal relationship between CMV infection and renal allograft rejection a number of mechanisms can be suggested to explain it. This was outlined by Lopez et at. in 1974 (4):

1. The virus might have a direct toxic effect on renal tissue through massive cytolytic replication. This, however, seems unlikely since in non-transplant patients with fulminant CMV disease deterioration of renal function has not been documented. Moreover, cytomegalic cells or CMV-related antigens have seldom been demonstrated in renal biopsies from transplanted kidneys, even in patients with severe CMV disease (4,106-108).

2. Pre-existing antibodies of any given specificity or combination of specificities may cause rejection, depending on the type and density of antigens present on the (endothelial) target cells within the donor graft. Depending on the immunoglobulin class to which the antibodies belong, rejection of the allograft may be caused by activation of complement or by antibodydependent cellular toxicity (ADCC) (109). CMV infection within the allograft might alter either the density of antigens present on (endothelial) target 


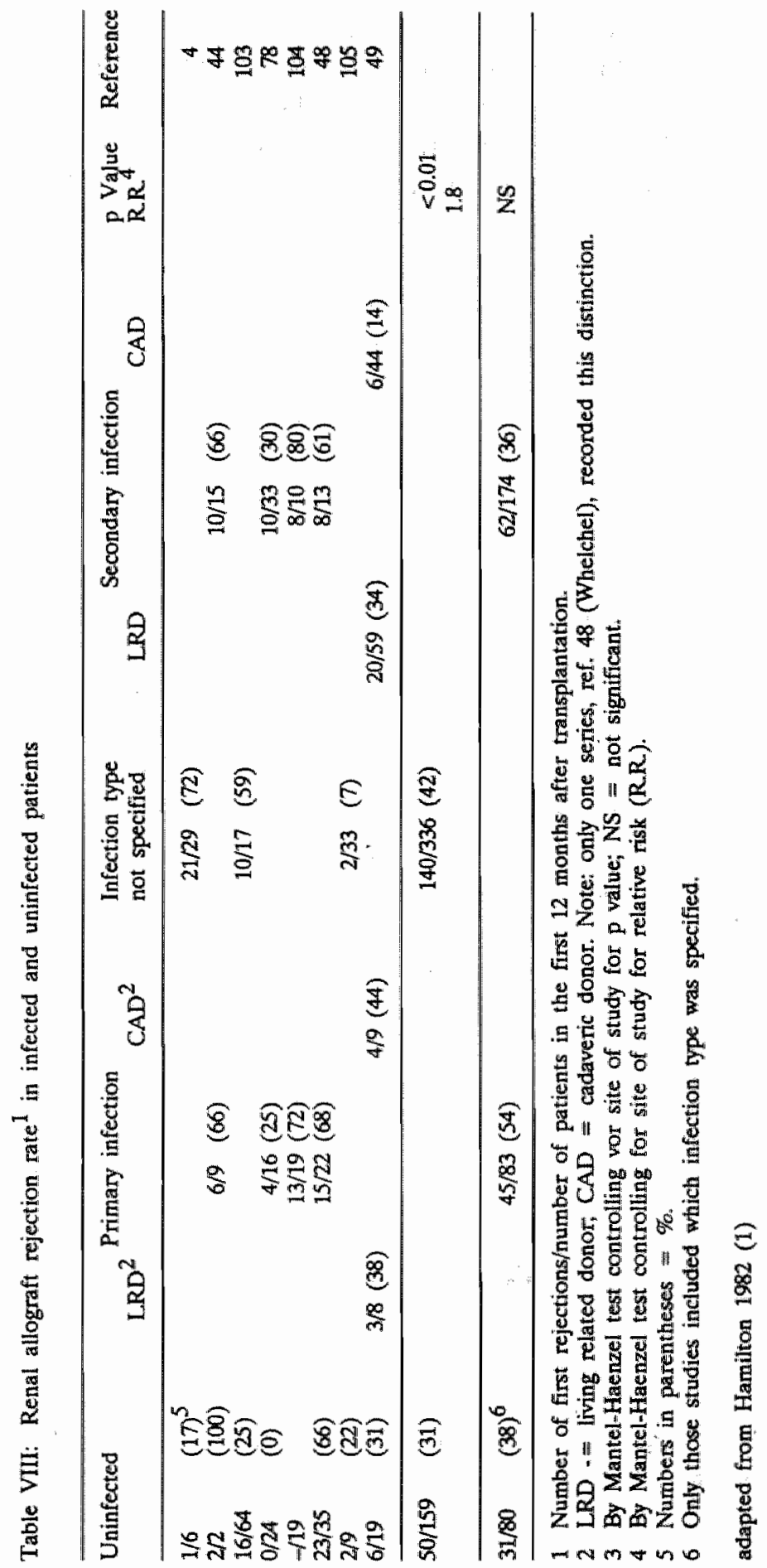


cells, or even alter the type of antigenic expression on these (infected) cells by a mechanism referred to as "antigenic shift" or "altered self". This alteration of antigen specificity of the Major Histocompatibility Complex (MHC) product is effected either by combinations of viral antigens with the MHC-antigens on the cell surface, or by alteration of MHC expression as a result of incorporation of viral DNA into the cell genome (110). This might thus enhance cellular and/or humoral cytotoxic responses towards the allogeneic kidney. Although cellular immunological responses are mostly grossly impaired in recipients of renal allografts under immunosuppressive therapy, humoral responses usually remain intact (80-84), leading to the possibility of the above described mechanism. In fact both humoral and cell-mediated immunity toward the allograft are frequently found. However, this has also been repeatedly demonstrated even with normally functioning allografts (4). However, this apparent discrepancy might be explained by differences in degree of immunological reactions and in the density of (altered) antigens in the allograft.

3. The virus might act as a nonspecific immunological stimulus or adjuvant upsetting the very delicate immunological balance between donor organ and host. Probably in most renal allografts there is some subclinical rejection (4) and, with time, a state of relative immunological adaptation of host to graft becomes established. Apart from antigenic adaptation of grafted renal vascular endothelium (111), most likely this immunological balance is, in part, brought about via a delicate balance between helper/suppressor mechanisms (11.2-114). Apart from helper/suppressor-mechanisms, the beneficial effect on survival of the graft from blood transfusions prior to transplantation is brought about by reversible inactivation of antigenspecific B-cells (109). CMV infections might interfere with the delicate immunological balance (115), either by influencing helper/suppressor cell ratios $(1,2)$, which in itself is associated with graft survival (116-119), or by aspecific (polyclonal) B- or T-cell stimulation $(2,120)$. Moreover this polyclonal stimulation might lead to the production of "auto"antibodies, cross-reacting with the donor-specific antigens (2,121-127). Interesting in this respect is the finding of Fujinami et al. (128), who demonstrated a sequence homology and immunological cross-reactivity between HCMV with HLA-DR $\beta$ chains. Recently von Willebrand et al. (129) demonstrated that during renal graft rejection, Class II antigen expression is increased in parenchymal cells of the graft. This renders an explanation of how an immunological response towards the virus might well have damaging effects on the host's own tissues, or on (semi)allogeneic tissues such as a renal transplant. 
As stated before, humoral and cell mediated immunity have been repeatedly demonstrated (4) towards functioning allografts. However, again it may be argued that it might be a matter of degree of immunological reactions towards the graft and the density of allo-antigens towards which these immunological reactions are directed, whether or not these mechanisms lead to allograft rejection.

4. Still another possibility to explain the association of allograft malfunction with viral infection is the formation of circulating viral antigen-antibody complexes which might lead to immune-complex nephritis (130-134). However, in the study of Lopez (4), in renal biopsies taken during rejection episodes no evidence of immune-complex nephritis was found. Moreover, antiviral antibody is mostly associated with reversal rather than initiation of rejection; and deterioration of renal function generally precedes seroconversion ( $\$ 6$ ).

5. CMV glomerulopathy

Four basic mechanisms of injury can be postulated as causing a glomerulopathy associated with CMV infection as was outlined by Herrera et al. (135). Basically they comprise the same mechanisms as outlined above:

a. A first possible mechanism forms the colonisation of the kidney by CMV (as discussed in item 1).

Support for this theory is found in cases of CMV associated with tubular interstitial nephritis (Cameron et al. 136). However, as stated before, cytomegalic cells or CMV-related antigens are only sparsely seen in the kidney, even in patients with severe disease $(4,106-108)$. Moreover in those cases they are not associated with glomerulopathy.

b. A toxic effect of disseminated CMV infection, resulting in direct endothelial cell damage is another possible mechanism. There are several infectious agents (rickettsiae and some viruses) wich can cause endothelial cell damage as the predominant manifestation of disease. The study of Herrera et al. (135), however, did not produce evidence for this process.

c. An immune-complex mediated process (item 4) as reported by Ozawa et al. (132), is a third possible mechanism of CMV-mediated glomerulopathy. Such a pathogenesis has been demonstrated in mice chronically infected with lymphocytic choriomeningitis virus (137) and lactic dehydrogenase virus (138), and viruses have been implicated in the immune complex nepritis observed in Aleutian mink disease (139) and the autoimmune nephritis in New Zealand Black mice (140). Moreover in mice an experimental model of acute and progressive cytomegalovirus glomerulonephritis was developed by Smith and Wehner (133-134). 
d. A specific rejection process triggered by a systemic CMV infection might be another possible mechanism (item 2). Acute viral infection and alloantigen stimulation occurring at the same time may act synergistically, activating T-cells, which may lead to generation of mature cytotoxic cells and other effector cells. This mechanism has been suggested by many authors $(4,141-143)$.

Tourkantonis (144) discussed extensively the immunopathological mechanisms involved in this interaction.

Gaston and Waer (145) demonstrated that effector T-cells, generated by allograft recipients in response to a given infection (CMV), may initiate graft rejection, when the particular alloantigens which they also recognize are present in the allograft (item 2).

6. Although many investigators have shown a statistical correlation between graft rejection and CMV infection and concluded that the virus is the causative agent inducing rejection, it might well be that rejection leads to viral reactivation rather than vice versa. Rejection processes probably start long before a clinical rejection episode is diagnosed, and rejection phenomena are mostly present in random biopsy specimens, even from well tolerated allografts (4). Moreover many investigators have shown in animal models that both $\mathrm{HvG}$ as GvH-reactions may activate latent virus infections, and in man too there is much evidence to support this (94-97, §6). Therefore, it might well be that the statistical correlation found between renal allograft malfunction and CMV infection is explained in that the rejection episodes activate latent virus, or stimulate pre-existing multiplication of the virus.

Increasing immunosuppresive drug administration to combat the rejection may then further lead to progressive CMV disease with its hazardous complications.

\section{II.8 CONCLUSIONS}

From the previous sections in this chapter it is clear that there are many factors that may influence the occurrence and severity of CMV infections. In addition, there are many factors that have been shown to be related to renal allograft malfunction and rejection. From the bulk of information offered by the numerous prospective and retrospective clinical studies, however, no clearcut conclusion can be drawn, and the evidence for a causative role for CMV infection in renal allograft rejection is inconclusive. 
Since it appears impossible to study separately the numerous factors mentioned on their effect both on CMV infection and renal allograft function, it seems inevitable that these have to be investigated in an animal model.

Since the rat model appears to be suitable for renal transplantation studies; and since the recently isolated Rat CMV (RCMV) closely resembles HCMV (Chapter III and IV), the combination of both offered an excellent opportunity to study more accurately the effect of CMV infections on renal allograft rejection. 


\section{REPERENCES TO CHAPTER II}

1. J.G. Hamilton. Cytomegallovirus and Immunity. Monographs in Virology. Karger Press 1982, Basel.

2. M. Ho. Cytomegalovirus. Biology and Infection. Current topics in infectious disease. Plenum Medical Book Company New York and London 1982.

3. J. Glenn. Cytomegalovirus infections following renal transplantation. Reviews of Infectious diseases 1981; 3: 1151-1178.

4. C. Lopez, R.L. Simmons, S.M. Maurer, J.S. Najarian, R.A. Good. Association of renall allograft rejection with virus infections. Am. J. Med. 1974; 56: 280-289.

5. R.H. Rubin, N.E. Tolkoff-Rubin, D. Oliver, T.R. Rota, J. Hamilton, R.F. Betts, R.F.Pass, W. Hillis, W.S. Szmuness, M.L. Farell, M.S. Hirsch. Multicenter seroepidemiologic study of the impact of Cytomegalowirus infection on renal transplantation. Transplantation 1985; 40: 243 249.

6. J.S. Najarian, D.S. Fryd, J. Strand, D.M. Canajax, N.L. Asher, W.D. Payne. A single institution, Randomized, Prospective trial of Cyclosporine versus Azathioprin-Antilymphocyte globulin for immunosuppression in renal allograft recipients. Ann. Surg. 1985; 210, 142-157.

7. M.R. Weir, B.C. Irwin, A.W. Maters, G. Genemans, S.Y. Shen, P. Charache, G.M. Williams. Incidence of CMV-disease in Cyclosporin-treated renal transplant recipients based on donor/recipient pretransplant immunity. Transplantation 1987; 15: 457.

8. P.K. Peterson, J.J. Rynasiewiez, RL Simmons, R.M. Ferguson. Decreased incidence of overt CMV disease in renal allograft recipient receiving cyelosporin A. Transplantation 1985; 40: 610 .

9. M.J. Bia, W. Andiman, K. Gardio, et.al. Effect of treatment with cyclosporin versus azathioptine on incidence and severity of CMV-imfection post transplantation. Transplant. Proc. 1983; 15: 457.

10. U. Krech. Complement fixing antibodies against $C M V$ in different parts of the world. Bull. WAO 1973; 49: 103-106.

11. U.H. Krech, M. Jung, F. Jong. Cytomegalovinus infections in man. pp. 1.105. Karger Press 1971, Basel.

12. H. Stern and H.D. Elek. The incidence of infection with CMV in a normal population. J. Hyg. (Camb.) 1965; 63: 79-87.

13. J.P. Luby and D.M. Shasby. A sex difference in the prevalence of antibodies to CMV.J. Am. Med. Ass. 1972; 222: 1290-1291.

14. P.U. Peterson, H.A. Balfour Jr, S.C. Marker, D.S. Fiyd, R.J. Howard, R.L. Simmons. CMVdisease in renal allograft recipients: A prospective study of the clinical features, risk factors and impact on renal transplantation. Medicine 1980; 59: 283-291.

15. R.L. Simmons, A.J. Matas, L.C. Ratazzi, H.H. Balfour Jr. R.J. Howard, J.S. Najarian. Clinical characteristics of the lethal CMV infection following renal transplantation. Surgery 1977; 82: $537-546$.

16. J.E. Craighead. Pulmonary CMV-infection in the adult. Am. J. Pathol. 1971; 63: 487-504.

17. P.E. Neiman, W. Reeves, G. Ray, N. Flournoy, K.G. Lerner, G.E. Sale, E.D. Thomas. A prospective analysis of interstitial pneumonia and opportunistic viral infection among recipients of allogeneic bone marrow grafts. J. Inf. Dis. 1977; 136: 754-767.

18. J.L. Waner, T.H. Weller, S.V. Kevy. Patterns of CMV-CFA activity: A longitudinal study of blood donors. J. Inf. Dis. 1973; 127: 538-543.

19. J. Clarke, R. Craig, R Saffro, P. Murphy, H. Yakoo. Cytomegalowirus granulamatous hepatitis. Am. I. Med. 1979; 66" 264-269.

20. J.B. Hanshaw, R.F. Betts, G. Sinnon, R.C. Boynton. Acquired CMV-infection. Association with hepatomegaly and abnormal liver-function tests. New Eng. J. Med. 1965; 272: 602-609.

21. A.I. Harris, R.J. Meyer, E.A. Brody. CMV-induced thrombocytopenia and hemolysis in an adult man. Ann. Intern. Med. 1975; 83: 670-671.

22. E. Klemola, R. Stenströ $m, R$ won Essen. Pneumonia as a clinical manifestation of $\mathrm{CMV}$. infection in previously healthy adults. Scand. J. Inf. Dis, 1972; 4: 7-10,

23. C.A. Phillips, W.L. Fanning, D.W. Gump, CC.F. Phillips. CMV-encephalitis in immunologically normal adults. Succesful treatment with Vidarabine. J. Am. Med. Ass. 1977; 238: 2299-2300,

24. P. Rosen, D. Armstrong, N. Rice. Gastro intestinal CMV-infections. Arch. Int. Med. 1973; 132: $274-276$. 
25. T.H. Weller. The Cytomegalovirus: ubiquitous agents with protean clinical mainifestations. New Eng. J. Med. 1971; 285: 203-214, 267-274.

26. $\mathbb{K}$ Wink, H. Sehmitz. CMV-myocarditis. Am. Heart. J. 1980; 100: 667-672.

27. E. Klemola, R. van Fssen, $O$. Wagner, $K$. Halthia, A. Koivuniemi, 1. Salmi. CMV Mononucleosis in previous healthy individualis. Am. J. Int. Med. 1969; 71: 11.

28. J.B. Hanshaw, A.P. Schreiner, A.W. Moxley, L. Gaew, V. Abel, B. Schreiner. School failure and deafness after "silent" congenital CMV-infection. New Eng. J. Med. 1976; 295: 468-470.

29. S. Stagno, D.W. Reynolds C.S. Amos, A.J. Dahle, F.P. McCallister, I. Mohindra, R Ermocilla, C.A. Alford. Auditory and visuall defects resulting from symptomatic and subclinical congenital CMV and toxoplasma infections. Pediatrics, Springfield 1977; 59: 669-678.

30. S. Stagno, D.W. Reynolds, E.S. Huang, S.D. Thames, R.J. Smith C.A. Alford Jr Congenital CMV-infection oecurence in an immune population. New Engl. J. Med. 1977; 296: 1254-1258.

31. G. Birnbaum, J.L. Lynch, A.M. Margileth, W.M. Lonergan, J.L. Sever. CMV-infections in newborn infants. J. Pediatr. 1969; 75: $789-795$.

32. D.W. Reynolds, S. Stagno, T.S. Hosty, M. Tiller, C.A. Alford. Maternal CMV-excretion and perinatal infection. New Engl. J. Med. 1973; 289: 1-5.

33. D.W. Reymolds, S. Stagno, K.G. Stubbs, AuJ. Dahle, M.M. Livingston, S.S. Saxon, C.A. Alford, Inapparent congenital $\mathrm{CMV}$-infection with elevated cord IgM levels: causal relation with auditory. and mental deficiency. New Engl. J. Med. 1974; 290; 291-296.

34. J.G. Starr, R.D. Bart, E. Gold. Inapparent congenital CMV-infection: clinical and epidemiologic characteristics in early infancy. New Eng. J. Med. 1970; 282: 1075-1077.

35. R.F. Betts, R.V.M. Cestero, R.B. Freeman, RG. Douglas Jr. Epidemiology of CMV-infection in end stage renal disease. J. Med. Virol. 1979; 4:89-96.

36. E.S. Spencer. CMV -antibody in uremic patients prior ro renal transplantation. Scand. J. Inf. Dis. 1974; 6: 14 .

37. D.J. Sexton, E.W.P. Smith, R.A. Gitmann, M.J. Alms, D.J. Lang. CMV-infection and chronic hemodialysis. Clin. Nephtol. 1979; 11: 3-6.

38. Medical Research Council Working Party on Post-transfusion Hepatitis. Reports to the MRV Blood Transfusion Research Committee. Post-transfusion hepatitis in a London hospital: results of a two-year prospective study. J. Hygiene. 1974; 73: 173-188.

39. G.R.G. Monif, G.I. Daicoff, L.L. Flory. Blood as a potential vehicle for the Cytonnegaloviruses. A.n. J. Obstet. Gyn. 1976; 126; 445-448.

40. J.A. Armstrong, G.G. Tarr, L.A. Youngblood, et.al. CMV-infection in children undergoing open heart surgery. Yale J. Of Biol. Med. 1976; 49: 83-91.

41. W.L. Bayer. The effect of frozen blood on the relationship of CMV and hepatitis virus to infection and disease. In: Clinical and Practical Aspects of the Use of Frozen Blood. (Ed.) R.B. Dawson and A. Barnes Jr. 1977; pp 133-174. Washington DC. American association of Blood Banks.

42. J.E. Craighead. Immunologic response to CMV-infection in renal allograft recipients. Amn $\mathrm{J}_{\text {. }}$ Epidem. 1969; 90: 506-513.

43. F.D. Pien, T.F. Smith, C.F. Anderson, M.L. Webel, H.F. Taswell. Herpeswiruses in renal transplant patients. Transplantation 1973; 16: 489-495.

44. M. Fiala, J.E. Payne, T.V. Berne, T.C. Moore, W. Henle, J.Z Montgomerie, S.N. Chatterjee, L.B. Geze. Epidemiology of CMV-infection after transplantation and imunosuppression. J. Inf. Dis. $1975 ; 132: 421-433$.

45. M. Ho, S. Suwransirikul, J.N. Dowling, L.A. Youngblood, J.A. Armstrong. The transplantated kidney as a source of CMV-infection. New Eng. J. Med. 1975; 293: 1109-1112.

46. H.H. Balfour Jr, M.S. Slade, J.M. Kalis, RJ. Howard, R.L. Simmons, J.S. Najarian. Viral infections in renal transplant donors and their recipienus: a prospective study. Surgery st. Louis $1977 ; 81: 487-492$.

47. A.G. May, R.F. Betts, R.B. Freeman, C.H. Andris. An analysis of CMV-infection and HLA antigen matching on the outcome of renal transplantation. Ann Surg. 1978; 187: 110-117.

48. R. CappeI, O. Hestermans, C. Toussaint, P. Verstraeten, D. van Beers, J. de Braekeleer, E. Schoutens. CMV-infection and graft survival in renal graft recipients. Arch. Virol. 1978; 56: 149-156.

49. J.D. Whelchel, R.F. Pass, A.G. Diethelm, R.J. Whitley, C.A. Alford Jr. Effect of primary and recurrent CMV-infections upon graft and patient survival after renal transplantation. 1979; 28: $443-446$. 
50. D.G. Pappas. Hearing impaiments and vestibular abnomalities among child ren with subclinical cytomegalovirus. Ann. Otol. Rhinol. Laryngol. 1983; 92: 552-557.

51. S. Saigal, O. Lunyk, P.P.B. Larke, M.A. Chernesky. The outcome in children with congenital CMV-infection. Am. J. Dis. Child. 1982; 136: 896-901.

52. W.D. Williamson, M.M. Desmond, N. La Fevers, L. H. Taber, F.I. Catlin, T.G. Weaver. Symptomatic Congenital Cytomegalovirus. Am. J. Dis. Child. 1982; 136: 902-905.

53. R.F. Betts, JB. Hanshaw. CMV in the immunocompromized host. Ann. Rev. Med. 1977; 28: 103 .

54. JN. Dowling A.R. Saslow, J.A. Armstrong, M. Ho. The relationship of immunosuppression to CMV infection Yale. J. Biol. Med. 1976; 49: 77.

55. R.H. Rubin. Infection in the renal transplant patient. In: R.H. Rubin, L.S. Young (Eds.). Clinical approach to infection in the compromised host, New York: Plenum: 1981: 553.

56. J.P. Wyatt, P.A. Hemsath, M.D. Soash "Disseminated Cytomegalic inclusion disease in an adult with primary refractory anaemia and transfusional sclerosis. Report of a case. Am. J. of Clin. Path. 1951; 21: 50-55.

57. I. Kreel, L.I. Zaroff, J.W. Canter, I. Krasna, I.D. Baronofsky. A syndrome following total body perfusion. Surgery Gynaec. Obstet. $1960_{i}$ 111: 317-321.

58. D.R Smith. A syndrome resembling infectious mononucleosis after open heart surgery. $\mathrm{Br}$. Med. J. 1964; 1: 945-948.

59. L. Kaarianinen, E. KJemola, J. Paloheimo. Rise of CMV antibodies in an infectious mono nucleosis-like syndrome after transfusion. Br. Med. J. 1966; 2: 1270-1272.

60. J.A. Paloheimo, R. von Essen, E. Klemola, et. al Subclinical CMV-infections and CMV-mononucleosis after open heart surgery. Am. J. Cardiology. 1968; 22: 624-630.

61. J.A. Embil, D.F. Folkins, E.V. Haldane, C.E van Rooyen. CMV-infection following extra corporeal ciculation in children. A prospective study. Lancet 1968; 2: 1151-1155.

62. K.M. Foster and I. Jack. A prospective sudy of the role of $\mathrm{CMV}$ in post-transfusion mononucleosis. New Eng. J. Med. 1969; 280: 1311-1316.

63. W. Henle, G. Henle, M. Scriba, et. al. Antibody responses to the EBV and CMV after open heart and other surgery. New Eng. J. Med. 1970; 282: 1068-1074.

64. A.J. Prince, W. Szmuness, S.J. Milian, D.S. David. A serologic study of CMV-infections associated with blood transfusions. New Eng. J. Med. 1971; 284: 1125-1131.

65. T. Luthardt, H. Siebert, I. Losel. et. al. CMV-infectionen bei Kindern mit Blut aus tauschtransfusion im Neugeboren alter. Klin. Wochenschrift 1971; 49: 81-86.

66. D.J. Lang, P.A. Ebert, B.M. Rodgers, et.al. Reduction of postperfusion CMV-infections following the use of leukocytnt recipient. Role of source of kidney. I. Inf. Dis. 1978; 137; 556563.

67. N.E. Tolkoff-Rubin, R.A. Rubin, E.E. Keller, et.al. CMV-imfection in dialysis patients and Personnel. Ann. Intern. Med. 1978; 89: 625-628.

68. A. Kumar, G.A. Nankervis, A.R. Cooper, et.al Acquisition of CMV-infection in infants following exchange transfusions: a prospective study. Transfusion 1980; 20; $327-331$.

69. H.J. Alter, R.H. Purcell, S.. Feinstone and G.E. Tegtmeier. Non A non B hepatitis: its relationship to CMV, to chronic hepatitis, and to direct and indirect test methods. In: Viral Hepatitis. Int. Symposion W. Szmuness, H.J. AJter and J.E. Maynard (Ed.). 1981; pp 279-294. Philadelphia: Franklin Institute Press.

70. R.F. Betts, R.B. Freeman, R.G. Douglas Jro, T.E. Tally, B. Rundell. Transmission of CMV. infection with renal allograft. Kidney Int. 1975; 8: 385-392.

71. R.F. Pass, W.K. Long, RJ. Whitley, S.J. Soong, A.G. Diethelm, D.W. Reynolds, C.A. Alford. Productive infection with CMV and HSV in renal transplant recipient. Role of source of kidney. I. Inf. Dis. 1978; 137; 556-563.

72. E.S. Spencer. Clinical aspects of CMV-infection in kidney-graft recipients. Scand. J. Inf. Dis. 1974; 6: 315-223.

73. G.A. Nankervis. CMV-infections is the blood recipient. Yale J. Biol. Med. 1976; 49: 13-15.

74. J.O.H. Tobin, M.J. Warrell, P.J. Morris. CMV-infection and renal transplantation. Lancet $1979 ; 1: 926$.

75. J.E. Grundy, M. Super, S. Lui, P. Saeny, P.D. Griffith. The source of CMV in seropositive renal allograft recipients is frequently the donor kidney. Transpl. Proc. 1987; 19: 2126.

76. P. Wertheim, C. Burman, J. Geelen, J. v.d. Noorda. Transmission of CMV by renal allograft demonstrated by restriction enzyme analysis. Lancet 1983; 1: 981. 
77. J.E. Grundy, J. Super, P.D. Griffith. Reinfection of a seropositive allograft recipient by CMV from donor kidney. Lancet 1986; 1: 159.

78. R.F. Betts, RB. Freeman, R.G. Douglas Jr. T.E. Talley. Cinical manifestations of renal allograft Cellular immunity and herpesvirus-infections in cardiac transplant patients. New Eng. J. Med. 1977; 296: 1372-1377.

79. RJ. Howard, I.M. Mattson, H.H. Balfour Jr. Effect of immunosuppression on humoral and cell medjated immunity to MCMV. Proc. Soc. Exp: Biol. Med. 1979; 161: 341-346.

80. M.W. Rytel, J. Balay. CMV-infection and immunity in renal allograft recipients: assessment of the competence of humoral immunity. Infect. Immun. 1976; 13: 1633-1637.

81. C.C. Linnemann Jr., C.A. Kauffman, M.R. First, G.M. Schiff, J.P. Phair. Cellular inmune response to CMV infection after renal transplatation. Infect. Immun. 1978; $22 ; 176-180$.

82. RJ. Howard, H.H. Balfour Jr. Cell mediated immunity to CMV in mice and in renal transplant recipients. Transplant. Proc. 1979; 11: 75-78.

83. R.B. Pollard, K.T. Rand, A. Arvin, T.C. Merigan. Cell mediated immunity to CMN and infection in normal subjects and cardial transplant patients. J. Inf. Dis. 1978; 137: $541-549$

84. K.H. Rand, L.E. Rasmussen, R.B. Pollard, A. Arvin, T.C. Merigan. Cellular immunity and herpesvirus-infections in cardiac transplant patients. New Eng. J. Med. 1977; 296: 1372-1377.

85. J.N. Dowling, A.R. Saslov, J.A. Armstrong, M. Ho. CMV-infection in patients receiving immunosuppressive therapy for rheumatologic disorders. J. Inf. Dis. 1976; 133; 399-408.

86. S. Chiba, S. Ikeda, Y. Agatsuma, T. Nakao. Active infection with CMV and herpes group viruses in children receiving corticosteroid therapy. Tohoku J. Exp. Med. 1972; 106: 265-270.

87. K. Takakashi, T. Yagisawa, S. Teraoka ${ }_{n}$ H. Toma, T. Gishi, S. Kobayashi. Viral infections in kidney transplant patients immunosuppressed with Cyclosporine. Transplant. Proc. 1987; 19: 2142-2149.

88. P.C. Johnson, R.M. Lewis, D.L. Golden, P.E. Oefinger, C.T. van Buren, R.H. Kerman, B.D. Kaham. The impact of $\mathrm{CMV}$-infection on seronegative recipients of seropositive donor kidneys versus seropositive recipients treated with Cyclosporine-prednisone immunosuppression. Transplantation 1988; 45: 116-121.

89. R.F. Pass, D.W. Reynolds, J.D. Whelchel, A.G. Diethelm, C.A. Alford. Impaired lymphocyte transformation response to CMV and PHA in recipients of renal transplants: Association with antithymocyte globulin. J. Inf. Dis. 1981; 143: 259.

90. S.H. Cheeseman, R.H. Rubin, J.A. Stewart, et. al. Controlled clinical trial of prophylactic human-lymphocyte interferon in renal transplantation: effects on CMV and HSV infections. New. Eng. J. Med. 1979; 300: 1345-1349.

91. M.O. Slade, R.L. Simmons, E. Yrnis, L.J. Greenberg. Immunodepression after major surgery in normal patients. Surgery $1975 ; 78$ : $363-372$

92. B.C. Wu, J.N. Dowling, J.A Armstrong, M. Ho. Enhancement of mouse CMV-infection during host versus graft reaction. Sience $1975 ; 190 ; 56-58$.

93. J.N. Dowling, B.C. Wu, J.A. Armstrong, M. Ho. Enhancement Of murine CMV-infection during graft versus host reaction. J. Infect. Dis. 1977; 135: 990-994.

94. J.D. Meyers, H.C. Spencer, J.C. Watts, M.B. Gregg, J.A. Stewart, R.H. Troupin, E.D. Thonas. CMV pneumonia after human marrow transplantation. Ann. Intern. Med. 1975; 82: 188.

95. J.D. Meyers, N. Flournoy, E.D. Thomas. Risk factors for CMV-infection after human martow transplantation. J. Inf. Dis. 1986; 153: 478-488.

96. D. Guyotat, R. Gibert, J. Chomel, E. Archimbaud, S. Bossod, J. Maupas, D. Fie re, M. Aymand. Incidence and Prognosis of CMW-infections following allogenic bone marrow transplantation. J. Med. Virol. 1987; 23: 393-399.

97. W. Miller, P Flynn, J McCullough, H.A. Balfour, A Gollman, R. Haake, P. McGlave, N. Ramey, J. Kersey, CMV-infection after bone marrow transplantation: an association with acute GVH disease. Blood 1986; 67: 1162-1167.

98. J.L. Fleiss. Statistical method for rates and proportions pp 109-129 (Wiley, New York) 1973.

99. A.L. Smiley, C.G. Wlodaver, R.A. Grosman, C.F. Barbex, L.F. Perloff, N.B. Tustin. The role of pretransplantant immunity in protection from CMV disease following renal transplantation. Transplantation 1985; 40: CMV disease.

100. D.P. Walker, M. Longson, N.P. Mallick, R.W.G. Johnson. A prospective study of cytomegalovirus and herpes simplex virus disease in renal transplant recipients. J. Clin. Pathol. 1982; 35: $1190-1193$. 
101. M.R. Weir, B.C. Irwin, A.W. Maters, G. Genemans, S.Y. Shen, P. Charache, G.M. Williams. Morbid outcome of CMV-negative transplant recipients receiving CMV-positive kidneys. Traneplant. Proc. 1987; 19: 2137-2141.

102. RL. Simmons, A.J. Matas, L.C. Rattazzi, H.H. Balfour, R.J. Howard, J.S. Najarian. Clinical characteristics of the lethal CMN-infection following renal transplantation. Surgery $1977_{\text {; }}$ 82: 537.545 .

103. W.E. Braun, G. Nankervis, L.H. Banowsky, D. Protiva, E. Biebert, M.C. McHenry. A prospective study of CMV infections in 75 renal allograft recipients. Proc. clin. Dial. Transplant. Forum $1976 ; 6: 8-12$.

104. S. Suwansirikul, N. Rao, J.N. Dowling, M. Ho. Primary and secondary CMV-infection. Arch. Intern: Med. 1977; 137: 1026-1029.

105. S.N. Chatterjee, G.W. Jordan. Prospective study of the prevalence and symptomatology of CMV-infection in renal transplant recipients. Transplantation $1979 ; 28: 457-460$.

106. T.F. Smith, KE. Holley, T.F. Keys, et.al. CMV studies of autopsy tissue I Virus isolation. Am. J. Clin. Pathol. 1975; 63: 854.

107. S. Naraqi, G.G. Jackson, O. Jonasson, J. Ruben. Search for latent CMV in renal allografts. Infect. Immunity $1978 ; 19: 694-703$.

108. G.A. Nankervis. Comments on CMV-infections in renal transplant patients. Yale J. Biol. Med. 1979; 49: 27-28.

109. G.D. Majoor. The role of antibody in renal allograft rejection. Maastricht, Thesis 1981.

110. J.W. Schrader, B.A. Cunningham, G.M. Edelman. Functional interactions of viral and histocompatibility antigens at tumor cell surface. Proc. Natl. Acad. Soi. USA 1975; 72 . 5066.

111. G.M. Williams, C.A. Kratajewski, F.J. Dagher, A.M.T. Haar, J.A. Roth, G.W. Santos. Host repopulation of endothelium. Transpiant Proc. 1971; 3: 869.

112. W.L. Elkins, I. Hellstrom, K.E Hellstrom. Transplantation tolerance and enhancement. Concepts and questions. Transplantation 1979; 18: 38-45.

113. B.M. Hall. Mechanisms maintaining enhancement of allografts I Demonstration of a specific suppressor cell. J. Exp. Med. 1985; 161: 123-133.

114. W.M. Padberg, et.al. Two phenotypically distinct populations of T-cells have suppressor capabilities simultaneously in the maintaince phase of immunologic enhancement. J. Immunol 1987; 13: 1751-1757.

115. C.H. Andrus, P.F. Betts, A.G. May, R.B. Freeman. CMV -infection blocks the beneficial effect of pretransplant blood transfusion on renal allograft survival. Transplantation 1979; 1 : 133136.

116. R.T. Schooley, M.S. Hirsch, R.B. Colvin, A.B. Cosimi, N.E. Tolkoff-Rubin, e.a. Association of herpesvirus-infections with $T$ lymphocyte-subset alteration, glomerulopathy and opportunistic infections after renal transplantation. New. Eng. J. Med. 1982; 308: 6.

117. B. Cohen, JJ. van Rood, C.R. Stiller. Second international symposium on immunological monitoring the transplant recipient. Transpl. Prac. 1981; 13; 3.

118. A.B. Cosimi. R.B. Colvin, R.C. Burton, R.H. Rubin, G. Goldstein e.a. Monoclonal antibodies for immunologic monitoring and treatment in recipients of renal allografts. New Engl. J. Med. 1981; 305: 308.

119. T.M. Ellis, H.M. Lec, T. Mohanakumar. Alterations in human regulatory T-lymphocyte subpopulations after renal allografting. J. Immunol. 1981; 127:2199.

120. A. van Es. Immunological and clinical factors influencing rejection of human renall allografts. Thessis. Leiden 1984.

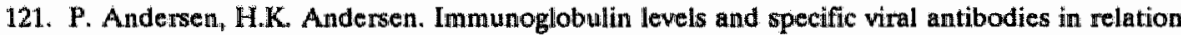
to smooth-muscle antibodies in CMV-infection. J. Clin. Lab. Immunol. 1979; 1: 133-136.

122. M.B.A. Oldstone; R.M. Welsh, B.S. Joseph. Pathogenic mechanisms of tissue injury in persistent wiral infections. Annals New York Academy of Sciences 19; :65-72.

123. A.L. Notkins, I. Koprowski. How the immune response to a virus can cause disease Scientific American 1973; 228: 23-31.

124. 1. Lubetzki-Korn, O. Abramski. Myasthenia gravis following viral infection. Eur. Neurol. 1981; 20: $435-439$.

125. P.H. Plotz. Autoantibodies are anti-jdiotype antibodies to antiviral antibodies. Lancet 1983; 2: 824 .

126. G.F. Botazzo, R. Puol-Burell, T. Hanafusa, M. Felidman. Role of aberrant HLA-Dr expression and antigen presentation in induction of endocrine autoimmunity. Lancet 1978; 1: 472. 
127. A.I. Harris, RJ. Meyer, E.A. Brody ex al. CMV-induced thrombocytopenia and hemolysis in an adult. Ann. Intern. Med. 1975; 83: 670-671.

128. R.S. Fujinami, J.A. Nelson, L. Walker, M.B.A. Oldstone. Sequence homology and immunologic cross-reactivity of buman CMV with HLA-DR申 Chain: a means for graft rejection and immunosuppression. J. Virol. 1988; 62: 100-105.

129. E. von Willebrand, E Petterson, J. Ahonen, P. Hayry. CMV-infection, class II expression, and human kidney allograft rejection. Transplantation 1986; 42: 364-367.

130. W.M. Baldwin, A. van Es, R.M. Valentijn, G.W. van Gemert, M.R. Daha, L.A. wan Es. Increased IgM and IgM immune-complex-like material in the circulation of renal transplant recipients with primary CMV-infection. Clin. Exp. Immunol. 1982; 50: 515-524.

131. W.P. Richardson, R.B. Colvin, S.M. Cheeseman, N.E. Tolkoff-Rubin e.a. Glomerulopathy associated with CMV-viremia in renal allografts. New Eng. J. Med. 1981; 305:57-63.

132. T. Ozawa, J.A. Stewart. Immune-complex glomerulonephritis associated with $\mathrm{CMV}$-infection. A.J.C.P. 1979; 72: 103-107.

133. RD. Smith, R.W.Wehner. Acute CMV-glomerulonephritis. An experimental modell Lab. Invest. $1980 ; 43: 278-286$.

134. R.W. Wehner, R.D. Smith. Progressive CMV-glomerulonephritis. An experimental model. Am. J. Pathol. 1983; 112: 313-325.

135. G.A. Herrera, R.W. Alexander, C.F. Cooley, R.G.Luke, D.R Kelly, J.J. Curtis, J.P. Gockerman. Cytomegalovirus glomerulopathy: A controversial lesion. Kydney Int. 1986; 29: 725-733.

136. J. Cameron ${ }^{\text {RJ. Rigby, A.G. van Deth }}$ J.J.B. Petrie. Severe tubulo-interstitial sidease in a renal allograft due to cytomegalovirus infection. Clin. Nephrol. 1985; 23: 1-11.

137. M.B.A. Oldstone, $\mathbb{F}$ J. Dizon. Pathogenesis of chronic disease associated with persistent lymphocytic choriomeningitis viral infection. I. Relationship of antibody production to disease in neonatally infected mice. J. Exp. Med. 1969; 129: 483.

138. S.M. Maurer, M.M. Steffes, M. Chern, D.M. Brown. Mesangial uptake and processing of macromolecules in rats with diabetes mellitus. Lab. Invest. 1979; 41: 401.

139. D.D. Porter, A.E. Larsen, H.G. Porter. The pathogenesis of Aleutian Mink disease of mink. 1. In vivo replication and the host antibody response to viral antigen. J. Exp. Med. 1969 130: 575 .

140. R.C. Mellors, T. Aoki, R.J. Huebner. Further implication of murine leukemia-like virus in the disorders of NZB mice. J. Exp. Med. 1969; 1045: 129.

141. P. Perlmann, H. Pelmann, H. Wigzell. Lymphocyte mediated cytotoxicity in vitro. Induction and inhibition by humoral antibodly and mature effector cells. Transplant. Rev. 1972; 13: 91114.

142. G. Trinchieri, M. De Marchi, W. Mayr, M. Savi, R. Ceppellini. Lymphocyte antibody lymphocytolytic interaction (LALI) with special emphasis on HLA. Transplant. Proc. 1973; 5: $1631-1646$.

143. R.B. Colvin, A.B. Cosimi, R.C. Burton, F.L. Delmonico, G. Jaffers, R.H. Rubin, N.E. TolkoffRubin, J.V. Giorgi, R.T. McCluskey, P.S. Russell. Circulatin T-cell subsets in 72 human renal allograft recipients. The OKT4 + $10 \mathrm{KT} 8$ + cell ratio correlates with reversability of graft injury and glomerulopathy. Transplant. Proc. 1983; 15: 116-1169.

144. A. Tourkantonis, A. Lazaridis. Interaction between $\mathrm{CMV}$ infection and renal transplant rejection. Kidn. Int. 1983; 23: 46-49 (suppl. 14).

145. J.S.H. Gaston, M. Waer. Virus-specific MHC-restricted T lymphocytes may initiate allograft rejection. Immunol. today 1985; 6: 237-239. 


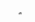




\section{CHAPTER III}

\section{RAT CYTOMEGALOVIRUS:}

CHARACTERIZATION OF THE VIRUS

AS A RAT CYTOMEGALOVIRUS AND

DETERMINATION OF ITS

GENOMIC STRUCTURE 


\section{INTRODUCTION}

Cytomegaloviruses (CMV) are members of the expanding group of Herpesviridae. They are probably, in terms of evolution, amongst the oldest viruses known. They have a history of a very long co-evolution with their natural hosts, which has resulted in a strong specificity to these hosts, and to a dependency on cellular enzymes of these hosts for their replication.

The biology of these individual viruses can only be studied in their particular virus-specific host; Human CMV (HCMV) can only be studied in human tissues or cell cultures and guinea-pig or mouse cytomegalovirus studies can only be performed in guinea-pig or mouse tissues/cells, respectively. Probably each animal species has its own specific CMV. In 1956 the first isolations of human CMV (HCMV) were reported $(1,2)$. Many investigators have since isolated CMV's from various species (3).

The spread of the virus among the naturall hosts is almost ubiquitous. Most infections are silent but still they can result in a wide spectrum of clinical disorders (Chapter II). HCMV has some very interesting characteristics in respect to its relationship to its host: firstly, the virus can turn into a "latent" state, a phenomenon that still is poorly understood, and secondly, during the acute phase of infection, it stimulates the synthesis of DNA, RNA and proteins in the host's infected cells.

HCMV contains double-stranded DNA with a molecular weight of $150 \times 10^{6}$ Daltons.

The HCMV genome contains inverted repeat sequences resulting in the possibility of the DNA adopting various isomeric forms. This was demonstrated for the HCMV by Kilpatrick et al. (1977) (4), La Femina (1983) (5) and Takekoski et al. (1987) (6). Because of its relationship to clinical pathology (Chapter II) and the characteristics mentioned above, the virus has received increasing attention in recent years.

\section{III.1 HISTORY OF THE VIRAL CLASSIFICATION}

CMV-related pathological effects were first described in the early years of this century by histopathologists who described the owl's eye intranuclear inclusions in tissues from foetuses with cytomegalic inclusion disease.

In 1956 three workers isolated $\operatorname{HCMV}(1,2,7)$. One of these three investigators, Weller (7), gave the virus its name from the effects produced in cell culture. 
The CMV's are morphologically similar to other members of the herpesvirus group; The central DNA-containing core is surrounded by a capsid containing 162 subunits or capsomeres, with five capsomeres along each edge of the triangular facet of the icosahedron.

The capsid is surrounded by an outer membrane, the envelope. The overall diameter of these complete virions is about $100-180 \mathrm{~nm}$ with a large range on account of the variations in size and shape of the envelope. The "naked" virus particle, or capsid, shows very little variation in size, and it has a symmetrical shape; the diameter is $105 \mathrm{~nm}$.

The virions of the various herpesviruses cannot be differentiated on the basis of their morphology as observed by electron microscopy. The viruses are however readily differentiated on the basis of their biological properties, the properties of the virus particle and the replication of the virus.

Table I: Classification of herpes viruses according to biological properties*

\begin{tabular}{|c|c|c|c|}
\hline \multirow[t]{2}{*}{ Properties } & \multicolumn{3}{|l|}{ Herpes viruses } \\
\hline & $\begin{array}{l}\text { Alpha herpes } \\
\text { virinae } \\
\text { (example: HSV) }\end{array}$ & $\begin{array}{l}\text { Beta herpes } \\
\text { virinae } \\
\text { (example: HCMV) }\end{array}$ & $\begin{array}{l}\text { Gamma herpes } \\
\text { virinae } \\
\text { (example EBV) }\end{array}$ \\
\hline Host specificity & variable & $\begin{array}{l}\text { narrow, fibroblasts } \\
\text { (in virro) }\end{array}$ & $\begin{array}{l}\text { limited, lymphocytes } \\
\text { (in vitro) }\end{array}$ \\
\hline Length of cycle & short & long & variable \\
\hline Cytopathic effects & rapid extension & $\begin{array}{l}\text { slow progression } \\
\text { of foci }\end{array}$ & variable \\
\hline Latent infection & nerve ganglia & numerous tissues & lymphoid tissues \\
\hline
\end{tabular}

- According to Roizman (1982).

The herpesviruses have been divided into three subgroups on the basis of their biological properties (Table I).

a. alphavirinae, that includes the Herpes simplex viruses;

b. betavirinae, that includes the cytomegaloviruses;

c. gammavirinae, including the lymphoproliferative viruses (e.g. EBV).

Later these subgroups were further subdivided (on the basis of their genome complexity) into genome-groups A-E as proposed in 1982 by Roizman (Table II) (8). 
Table II: Classification of human herpes viruses by genome complexity*

\begin{tabular}{|c|c|c|c|c|}
\hline $\begin{array}{l}\text { Provisional } \\
\text { name }\end{array}$ & Common name & $\begin{array}{l}\text { Sub- } \\
\text { family }\end{array}$ & $\% \mathrm{G}+\mathrm{C}$ & $\begin{array}{r}\text { Genome group } \\
\text { (Mol.wt.x10 }\end{array}$ \\
\hline HHV 1 & $\begin{array}{l}\text { Herpes simplex } \\
\text { virus type } 1\end{array}$ & $\alpha$ & 67 & E (96) \\
\hline HHV 2 & $\begin{array}{l}\text { Herpes simplex } \\
\text { virus type } 2\end{array}$ & $\alpha$ & 69 & E (96) \\
\hline HHV 3 & $\begin{array}{l}\text { Varicella-zoster } \\
\text { virus }\end{array}$ & $\alpha$ & 46 & D $(79-100)$ \\
\hline HHV 4 & Epstein Barr virus & $\tau$ & 59 & $C(114)$ \\
\hline HHV 5 & Cytomegalovirus & $\beta$ & 58 & E (145) \\
\hline
\end{tabular}

- According to Roizman (1982).

In 1979 Mathews (9) described the main characteristics of the CMV group as follows:

1. Properties of the virus particle

Its DNA has a molecular weight of $130-150 \times 10^{6}$ daltons with $56 \% \mathrm{G}+$ C. Sequences from either or both termini may be present in an inverted form internally.

2. Replication

The CMV group has a relatively slow reproductive cycle of $>24 \mathrm{~h}$, forming slowly progressing foci in cell culture. Enlargement of the infected cells occurs in vivo and often in vitro (cytomegaly).

Inclusion bodies containing DNA may be present in the nuclei and cytoplasm late in infection.

Latent wirus infection is frequently present in the salivary gland and/or other tissues.

3. Biological aspects

The host range is narrow; in cell culture CMV usually grows best in fibroblasts, but there are exceptions.

\section{III.2 ISOLATION AND CHARACTERUZATION OF RAT CMV}

\section{a. Isolation of $R C M V$}

In an attempt to isolate rat CMV (RCMV) wild rats were trapped near refuse dumps and canals.

Blood was sampled and biopsies were taken from the liver, kidney, spleen and salivary glands. 
An infectious virus-like agent was isolated from one of ten wild brown rats (Rattus norvegicus) obtained in one locality in the southern part of the Netherlands. The agent was predominantly present in the salivary glands, but also in the spleen (Table III) (Bruggeman et al. 1982) (10).

Table III: Isolation of the virus from wild rats

Organs tested for

presence of virus
Number of rats positive upon culture on REF-monolayers/ numbers of rats tested

\begin{tabular}{ll}
\hline Salivary glands & $8 / 10$ \\
\hline Spleen & $1 / 10$ \\
\hline
\end{tabular}

Upon inoculation of the organ homogenates on to rat embryonic fibroblast (REF) cultures a typical cytomegalovirus-like cytopathic effect (CPE) was produced (Fig. 1).

Fig. 1: Cytopatic effect of $R C M V$ in rat embryonic fibroblasts

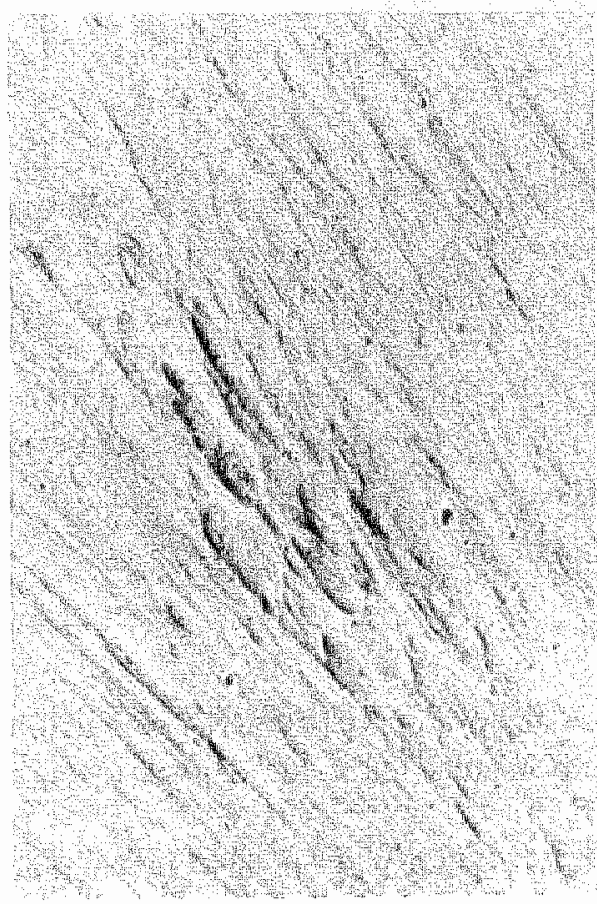

a. focal lesion (unstained; x 350)

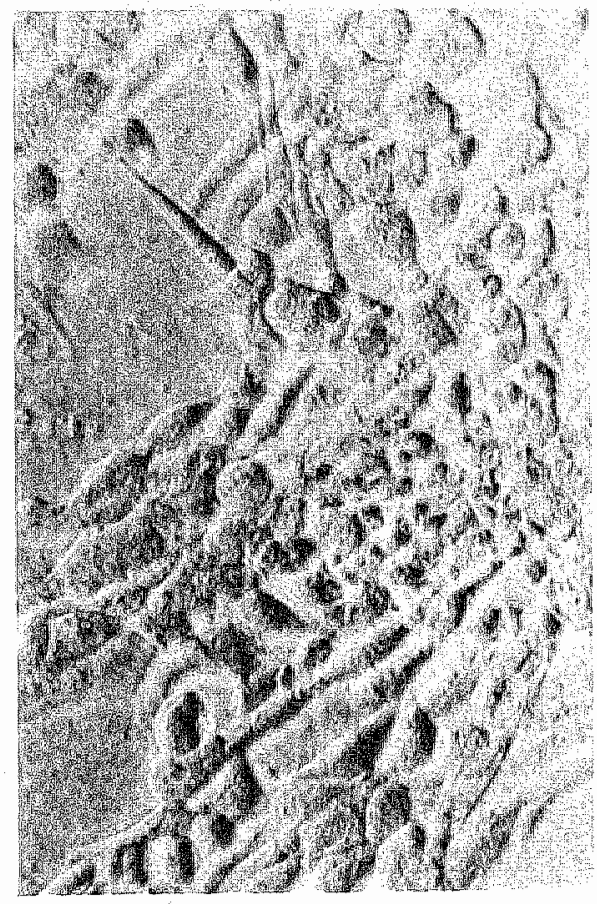

b. advanced cpe (unstained; x 350) 
Infectivity of the isolated virus-like agent was tested in laboratory rats (Lewis and Brown Norway), and propagated in order to obtain a pool for further study.

Three-weeks old immunosuppressed Lewis rats were inoculated intraperitoneally (i.p.) with either a salivary gland suspension or a splenic cell suspension from the wild rats (11). A third group was infected ip. with a tissue culture suspension that showed the characteristic cytomegalovirus-like cytopathic effect.

In all three cases it was possible to transfer the virus-like agent.

Transmission of the virus-like agent was tested by culturing the agent from the salivary glands of the recipient laboratory rats three weeks after inoculation.

Immunosuppression (with cyclophosphamide) was done in order to obtain higher quantities of the virus-like agent.

Transmission of infection to immunocompetent animals appeared to be almost as effective as that to immunosuppressed laboratory rats, although virus titres in the various organs, as determined by plaque titration assays, remained much lower in the immunocompetent rats (11). This is further discussed in Chapter $\mathrm{V}$ on the natural history of the virus infection.

\section{b. The virus particle}

The morphology of the infectious virus-like agent that caused the characteristic cytopathic effect in cultured monolayers of rat embryo fibroblasts (REF; Fig.1) was studied by electron microscopy.

Using the negative staining technique (12) naked particles (nucleocapsids) were observed with an overall diameter of $92-95 \mathrm{~nm}$. The nucleocapsids were surrounded by an outer layer (envelope) with a very variable shape and size (Fig. 2).

\section{c. General structure of the RCMV genome}

Data obtained by restriction endonuclease analysis of RCMV DNA revealed a molecular weight of the genome of approximately $138 \times 10^{\circ}$ daltons (Meijer et al., 1986) (13).

An independent size determination of RCMV-DNA was obtained by contour length measurements of high molecular weight DNA (according to Davis et al. 1971) (14). 
The DNA of the RCMV appeared to be linear without nicks, single stranded regions, or other such features.

Based upon the length of SV40-DNA (an internal standard for DNA length measurements), the length of the RCMV DNA varied between 69.0 and 80.0 $\mu \mathrm{m}$, with an average of $74.8(+/-5.0) \mu \mathrm{m}$, indicating an average molecular weight of $144(+/-9) \times 10^{6}$ daltons. The buoyant density was determined (Meijer et al., 1984) (13) by centrifugation in $\mathrm{CsCl}$ to equilibrium and averaged between 1.716 and $1.700 \mathrm{~g} / \mathrm{cm}^{3}$. This closely resembles the densities of the HCMV as determined by Huang et al. (1973)(15).

Recently, the RCMV genome has been cloned as restriction endonuclease fragments and the general structure (physical map) has been constructed (Meijer et al., 1986) (16). It has been concluded that the RCMV genome consists of a long unique sequence of 224 kilobases without internal inverted repeat sequences, and this is similar to the structure of murine and guineapig CMV DNA.

Fig. 2: Detailed electron micrograph of enveloped RCMV particle containing two nucleocapsids. Negative staining technique ( $x$ 170.000)

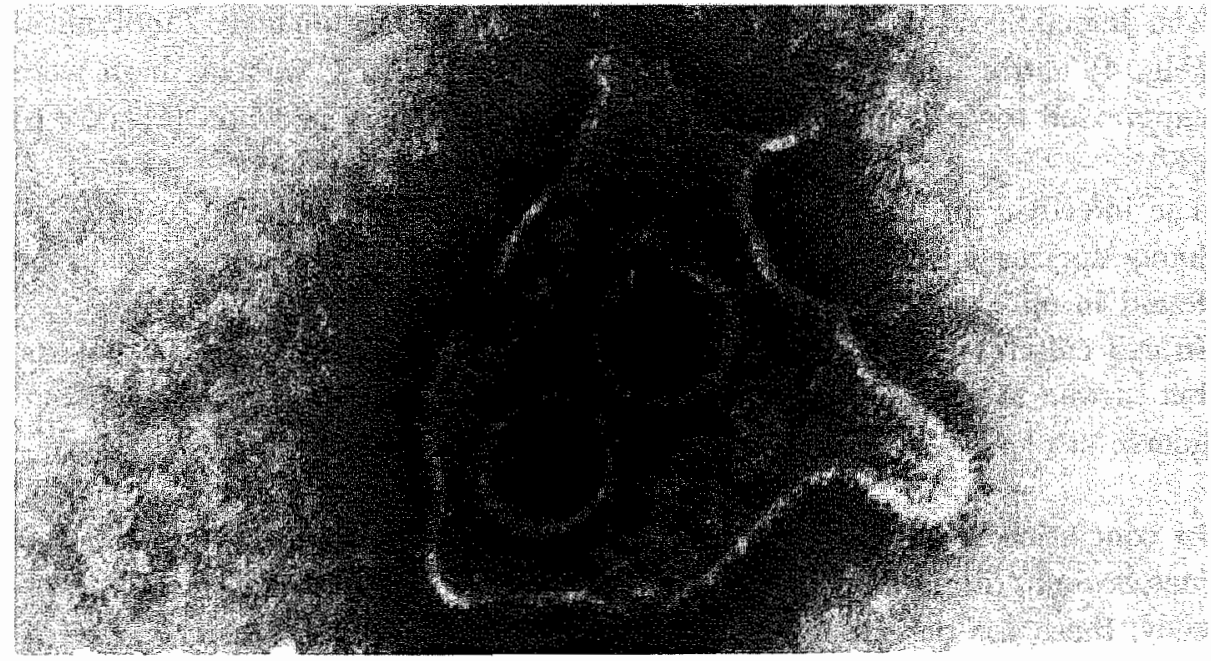

d. Replication in vitro

Another criterion for a Herpesvirus to be included within the group of cytomegaloviruses was its relatively slow replication cycle of more than $24 \mathrm{~h}$, forming slowly progressing foci in cell cultures. The virus-like agent isolated from the salivary glands of wild rats showed characteristic cytopathological changes in cultured REF after 3-4 days. It appeared in small foci (Fig. 1a), slowly progressed in the whole cell monolayer, and mostly attained the maxi- 
mum CPE after 7-10 days (Fig. 1b), depending on the infective dose. In hematoxylin-eosin stained infected REF cultures, characteristic enlarged cells were observed with eosinophilic cytoplasmatic and nuclear inclusion bodies. The nuclear inclusion bodies were surrounded by halos (i.e. owls-eye cells).

\section{e. Biological aspects}

As discussed above, the virus is harboured preferentially in the salivary glands in wild rats:

Infection of laboratory rats resulted in the presence of virus in many organs during the first week post infection (acute infection). Subsequently the infectious virus disappeared from these organs except for the salivary glands, where high virus titres were obtained at 4 to 8 weeks post infection.

The virus persisted in the salivary glands for several weeks to several months, depending on the rat strain used (chronic infection) (11, 17). After this period infectious virus could not be detected anywhere in the animal (latent infection).

The infection resulted in the appearance of humoral immunity (antibodies) (Fig. 4) and cellular immunity (Fig. 5) towards RCMV, whereas both were suppressed towards other antigens during acute primary infection (Figs $5+6$ ) (17).

The infectivity of this CMV-like organism of rat origin appeared to be absolutely species specific; no evidence of complete viral replication could be found in mice or in cell cultures of either mouse or human origin.

In cell cultures the RCMV appeared to grow best in homologous fibroblasts, but proved to grow almost as well in homologous cardiac endothelium (Bruggeman et al., 1985) (18).

In conclusion it can be decided that, since the virus isolated from wild rats matches all criteria mentioned for Herpesviridae in general and, more specifically, those for the group of cytomegaloviruses, this vinus is a rat cytomegalovins (RCMV). 
Fig. 3: Vinustitres in various organs and vinusexcretion during acute RCMV infection in Lewis rats.
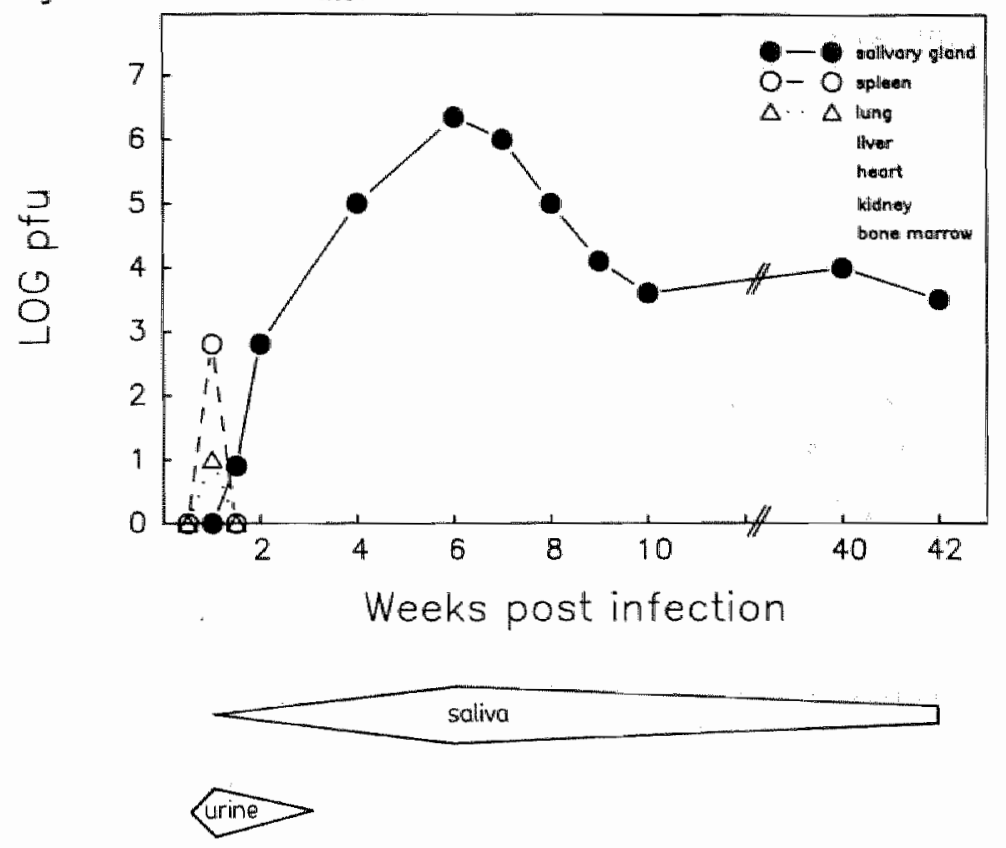

RCMV excretion

Lewis rats were inoculated with $10^{3}$ PFU of RCMV i.p. At various times post inoculation virus titres were determined in the various organs mentioned, as well as in urine and saliva by plaque assay. Each point represents the mean value of at least 3 rats.

Fig. 4: Development of humoral immunity towards RCMV infection.

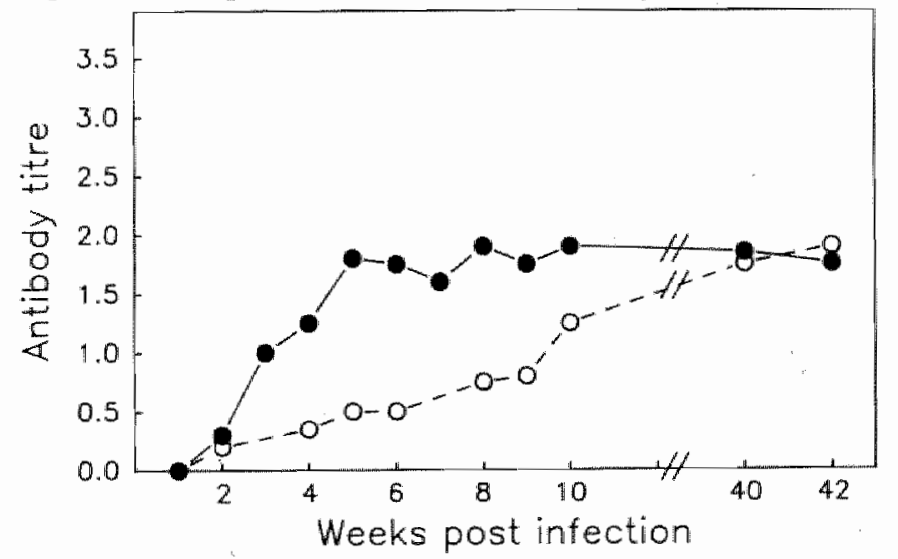

Lewis rats (open circles) and Brown Norway rats (closed circles) were inoculated with $10^{5}$ PFU of RCMV i. p.. At wreekly intervals post infection RCMV-antibodies were determined with an ELISAtechnique. Antibody titres are expressed as difference in optical density at $294 \mathrm{~nm}$ between positive and control antigen $(\triangle E)$. 
Fig. 5: Development of cellular immunity towards RCMV infection, in relation to development of humoral immunity towards RCMV infection, and RCMVtitres detected in the spleen.

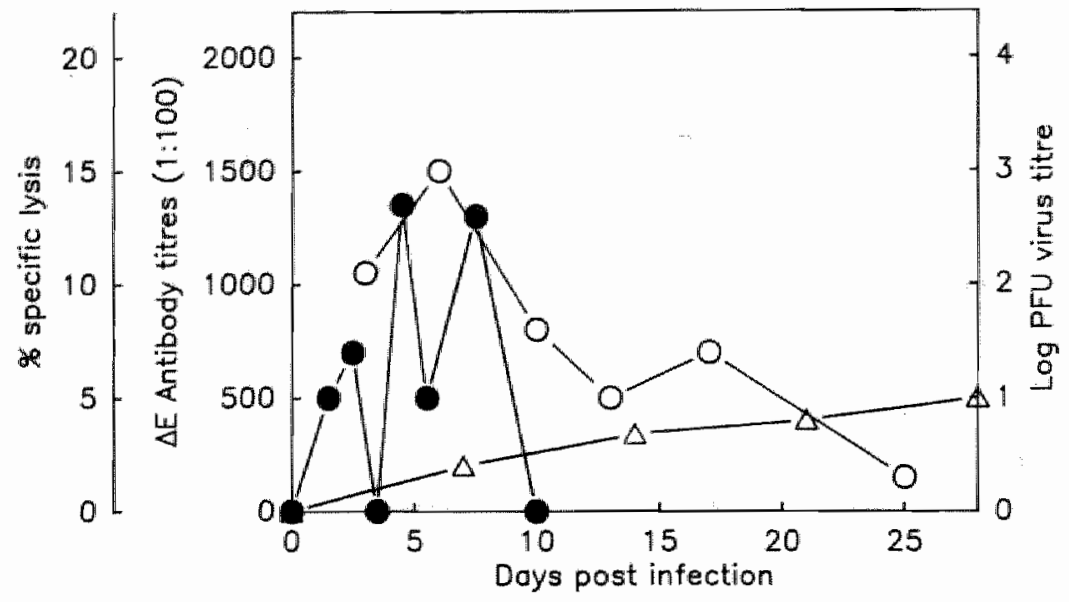

Lewis rats were inoculated with $10^{5}$ PFU of RCMV i.p. At various times post infection virus titres. were determined in the spleens by plaque assay, RCMV-antibody titres by ELISA and presence of RCMV-specific cytotoxic lymphocytes in the spleens by ${ }^{31} \mathrm{Cr}$-release assay. Virus in the spleens is expressed as $\log _{2}$ o PFU, antibody titres as $\triangle \mathrm{E} \times 10^{3}$, i.e. difference in optical density at $294 \mathrm{~mm}$ between positive and control antigen.

Fig. 6: Depression of humoral immunity towards other antigens, in relation to $R C M V$ titres in the spleen during acute RCMV infection.

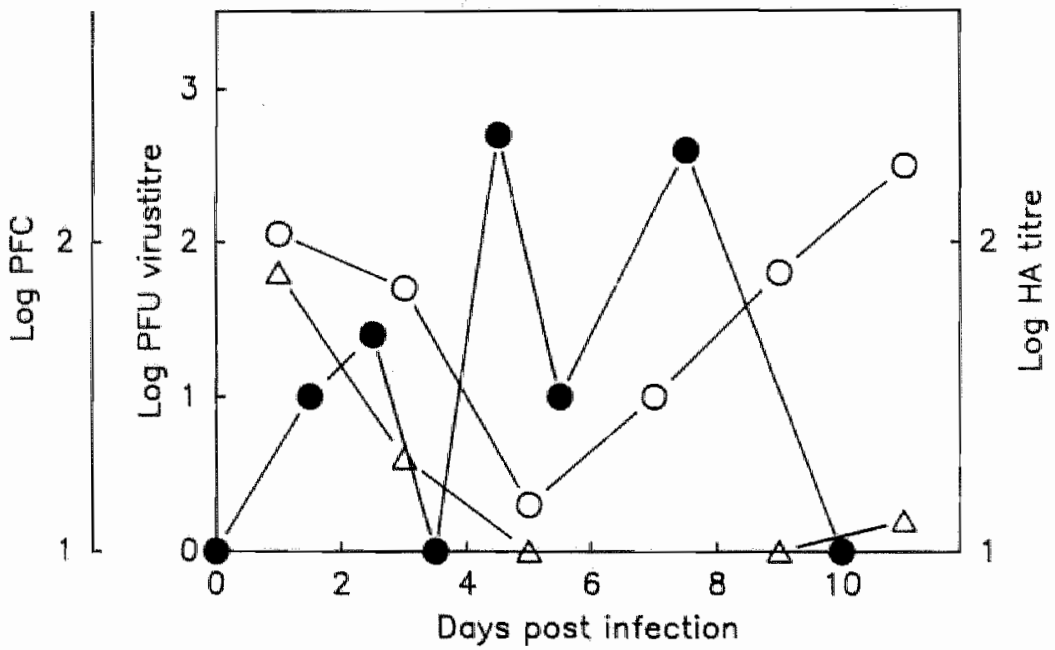

Lewis rats were inoculated with $10^{5}$ PFU of RCMV i.p., followed by immunisation with $10^{\circ}$ sheep red blood cells (SRBC) at different days post inoculation. The plaque forming cells (PFC) in the spleens (open circles) and haemagglutination titres (open triangles) in the serum were measured 3 days post SRBC-immunization. Each point represents the mean value of at least 3 rats. Virus titres in the spleens were determined by plaque-assay. 


\section{3 VIRUS RELATED PROTEINS IN INFECTED CELLLS}

\section{a. Introduction}

During cytomegalovirus infection two categories of protein appear in the infected cells (19).

Firstly, proteins appear that are directly associated with the virus itself: the virus-coded structural and non-structural proteins.

Secondly, the virus infection seems to stimulate the expression of some host cell associated proteins which are so closely related to the viral polypeptides that they cannot be distinguished from them whereas, on the other hand, other cellular proteins are suppressed by the virus $(13,20)$.

What happens when an active virus infection changes into a latent state, especially in respect to the expression or disappearance of virus-induced antigens, is unknown.

The biological significance of the different categories of viral antigens described, the role of these antigens in viral replication, and their possible role in the induction of renal allograft rejection are far from clear, as is the role of the development of anti-CMV immunity.

The first step in elucidating some of these questions was the characterization of the proteins composing the virion, followed by the determination of the antigens that are induced by the virus infection, and expressed on cellular membranes, nuclei, or within the cytoplasm.

\section{b. The structural proteins of the virion}

Radioactively-labelled virions and nucleocapsids of RCMV were analyzed by SDS-polyacrylamide gel electrophoresis (SDS-PAGE). Nucleocapsids have been found to contain one major protein of $138 \mathrm{kD}$, which is considered to be the basic invariable structural element of RCMV. Enveloped virions consist of 28 different proteins, five of which can be clearly identified as glycoproteins (58, 64, 76, 112 and $118 \mathrm{kD}$ ). In Fig. 7 the structural proteins composing the complete virion, (as detected by SDS-PAGE), are summarized (Meijer et al., 1984) (13). 
c. The vinus-induced proteins that appear in the course of in vitro infection in $R E F$

In the course of a CMV infection, various proteins are synthesized and these can be divided in three groups, namely:

The first proteins to be synthesised ( $\alpha$ or immediate-early) allow the transcription of the messenger RNA for the second group of proteins ( $\beta$ or early). The early proteins allow DNA replication to proceed and are followed by the appearance of the late proteins ( $\tau$ or late).

Immediate early antigens (IEA) Before viral DNA is synthesised, a number of antigens appears in the nucleus very early after infection (20 min $-1 \mathrm{~h}$ ). These antigens were first discovered by Michelson-Fiske et al. (1977) (21), and were called "Immediate Early Antigens" (IEA). They appear in permissive and in non-permissive cells (abortive infection); they appear significantly earlier than a CPE. For RCMV the appearance of IEA in infected rat embryonic fibroblasts (REF) is illustrated in Fig. 8.

Fig. 7

\section{RCMV STRUCTURAL PROTEINS}

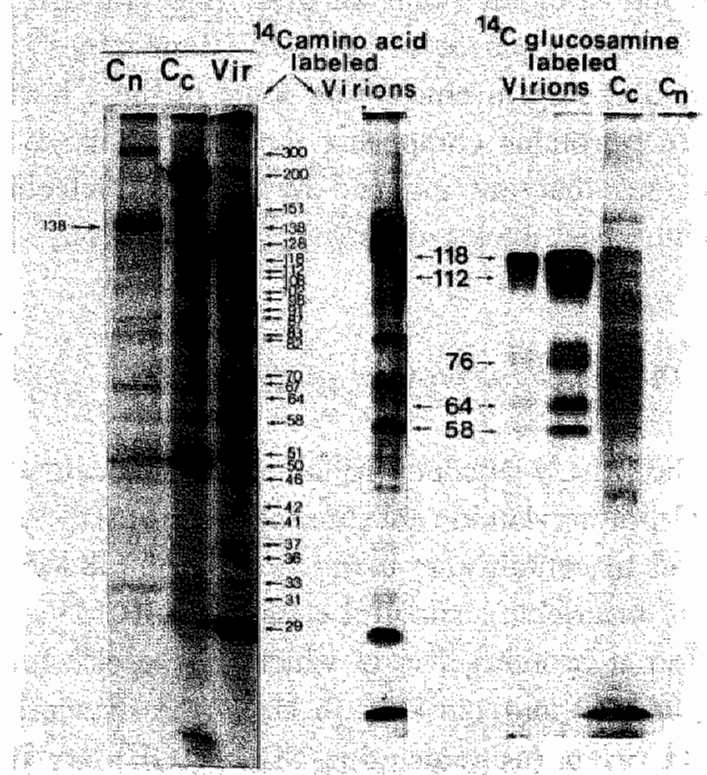

Filuorograms of RCMV structural proteins present in nuclear nucleocapsids $\left(C_{n}\right)$, cytoplasmic nucleocapsids $\left(\mathrm{C}_{\mathrm{s}}\right)$ and extracellular virions (vir). $\mathrm{RCMV}$ infected REF cells were continuously labelled with ${ }^{14} \mathrm{C}$-amino acids or ${ }^{14} \mathrm{C}$-glucosamine to label viral proteins or glycoproteins, respectively, as described in Methods. Virions and nucleocapsids were highly purified as judged by lectron-microscopic examination. Samples of ${ }^{14} \mathrm{C}$-amino acid-labelled $\mathrm{C}_{\mathrm{n}}(10,000 \mathrm{cts} / \mathrm{min}$ per lane), Co $\left(30,000 \mathrm{cts} / \mathrm{min}\right.$ per lane) and vir $\left(40,000 \mathrm{cts} / \mathrm{min}\right.$ per lane) or ${ }^{14} \mathrm{C}$-glucosamine-labelled wir (20,000 and $100,000 \mathrm{cts} / \mathrm{min}$ per lane), $C_{c}$ (30,000 cts/min per lane) and $C_{n}(2,000 \mathrm{cts} / \mathrm{min}$ per lane) were submitted to electrophoresis. 
Fig. 8: Immediate-early $R C M V$-induced proteins in rat embryo fibroblasts ("continuous labelling").

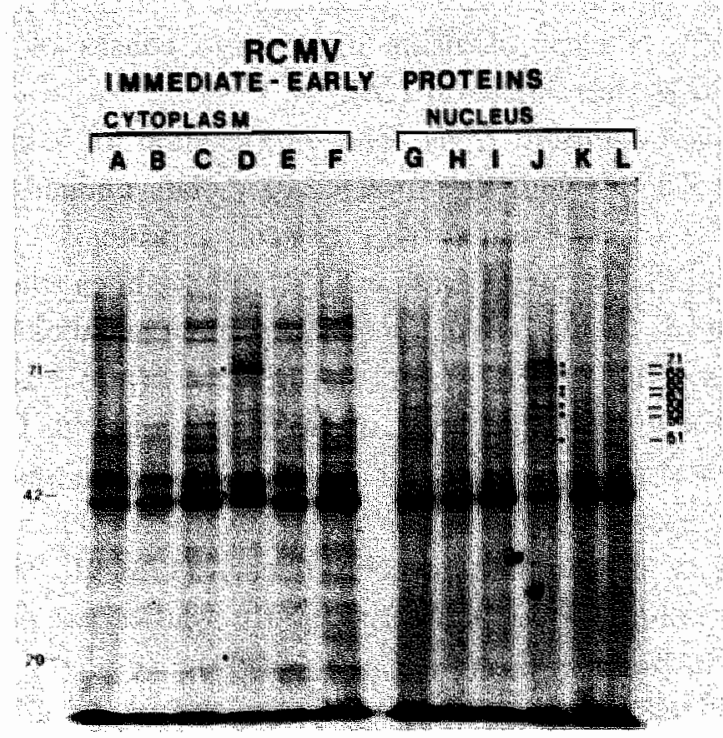

Confluent REP monolayers were infected with RCMV (2 PFU/cel) or mock-infected and incubated for $7 \mathrm{hr}$ in absence or presence of cycloheximide $(100 \mu \mathrm{g} / \mathrm{ml})$ and or actinomycin-D $(20 \mu \mathrm{g} / \mathrm{ml})$ in BME medium. Inhibitors were also present $1 \mathrm{hr}$ before and during infection (1 hr). After infection medium was methionine-deficient $+5 \mu \mathrm{Ci} / \mathrm{ml}{ }^{35} \mathrm{~S}$ methionine. After $7 \mathrm{hr}$. cells were washed 3 times with PBS and pulse-labelled for $90 \mathrm{~min}$. with ${ }^{35} \mathrm{~S}$ methionine $(5 \mu \mathrm{Ci} / \mathrm{ml})$ in methionine deficient medium. Cells were washed with PBS, collected and allowed to settel $(30 \mathrm{~min}$. on ice) in $10 \mathrm{mM}$ Tris buffer pH7.5.

Intact nuclei were released from the cells by Dounce homogenisation and collected by centrifugation on a $0.25 \mathrm{M}$ sucrose cushion.

Results

In Fig. 8 lanes $A, C, E, G, I$ and $K$ represent mock-infected REF cells whereas tanes $B, D, F, H_{r} l$ and $L$ represent $R C M V$-infected REF cells.

Without cycloheximide (lanes $A, B, G, H$ no accumulation of immediate-early (IE) RNA occurs and IE-proteins are beyond the detection limit. Howewer, following cycloheximide-biock (lanes $\mathrm{C}, \mathrm{D}, \mathrm{L}, \mathrm{J}$ ) the newly synthesised IE-RNA is accumulated and actively translated.

In lane $\mathrm{D}_{11}$ one major IE protein of $71 \mathrm{kD}$ and two minor IE-proteins of 42 and $29 \mathrm{kD}$ emerge. In the nucleus five other IE-proteins are seen (lane J).

When actinomycin $D$ was also present (lanes $\mathbb{E}, F, K, L$ ) any transcription was blocked. 'This experiment excludes the possibility that the input RCMV would carry some (IE) RNA and proves that the appearance of IE-proteins is due to immediate and active transcription of (a part) of the RCMV genome.

Early antigens ( $E A)$ Later in the course of infection, after approximately $5 \mathrm{~h}$, antigens appear predominantly in the cytoplasm and the outer cell membrane, mostly together with early cytopathic effects. Frequently, these events coincide with early cytoplasmic inclusions that develop into eosinophilic perinuclear beads, a phenomenon that is considered as a hallmark of CMV infection. These antigens are called Early Antigens (EA). These cytoplasmic inclusions, first 
thought to consist of aggregates of lysosomes, were proven to contain viral subunits by Craighead et al. (1972) (22). They contain no DNA (23) but are essentially composed of the same structural proteins as viral capsids $(23,24$, 25). Nuclear inclusion bodies also consist of EA and usually develop about 96 h after infection (26).

Late antigens (LA) The propagation of complete infective virions mostly coincides with the appearance of late antigens (LA). Probably these antigens are only related to viral structural proteins.

RCMV induced proteins in REF have been studied by Meijer et al. (1986) (20). As is shown in Fig. 9, cellular protein metabolism is hardly affected by RCMVinfection up to 1 day post infection (p.i.) whereas typical viral products are below detection level. At 42 hours p.i. and, (more clearly), at 66 h p.i. synthesis of some cellular nuclear and cytoplasmic proteins is substantially suppressed. At $66 \mathrm{~h}$ p.i. when advanced CPE is observed, active synthesis of new cytoplasmic proteins occurs $(138,91,78,62,47,45,40$, and $18 \mathrm{kD})$, whereas in the nucleus 9 newly synthesised proteins are detectable $(138,98$, $93,87,56,48,46,41$, and $32 \mathrm{kD}$ ).

Finally, three cytoplasmic proteins $(106,84$ and $33 \mathrm{kD})$ are easily recognised as virus-enhanced cellular proteins.

Comparison of these proteins with the protein composition of complete virions shows that most of the de-novo synthesised cytoplasmic and nuclear proteins are virion constituents.

Nevertheless, one non-structural protein in the cytoplasm $(78 \mathrm{kD})$ can be clearly identified.

Using pulse-labelling techniques on RCMV infected REF, after removal of a previously established translation-block by cycloheximide, two RCMV-induced immediate early (IEA) proteins ( 71 and $85 \mathrm{kD}$ ) have been detected both in the nuclear and in the cytoplasmic cell fractions. This is shown in Fig. 7.

d. Comparison of structure of RCMV with Cytomegalovinuses of other species

The RCMV genome is slightly smaller than the genomes of human CMV $\left(155 \times 10^{6}\right.$ to $158 \times 10^{5}(27,4,28,29)$ ), mouse CMV $\left(155 \times 10^{6}\right.$ (30) to $159 \times 10^{6}$ (31)) and guinea-pig CMV $\left(158 \times 10^{6}(32)\right)$ but is larger than equine CMV $\left(126 \times 10^{6}(33)\right)$.

The mapping results with RCMV lead to the conclusion that the RCMV genome consists of a long unique sequence of 224 kilobases without internal inverted repeat sequences, which is similar to the structures of murine and guinea-pig CMV DNA. 
Fig. 9 Metabolism of (viral) proteins in RCMV infected cells.
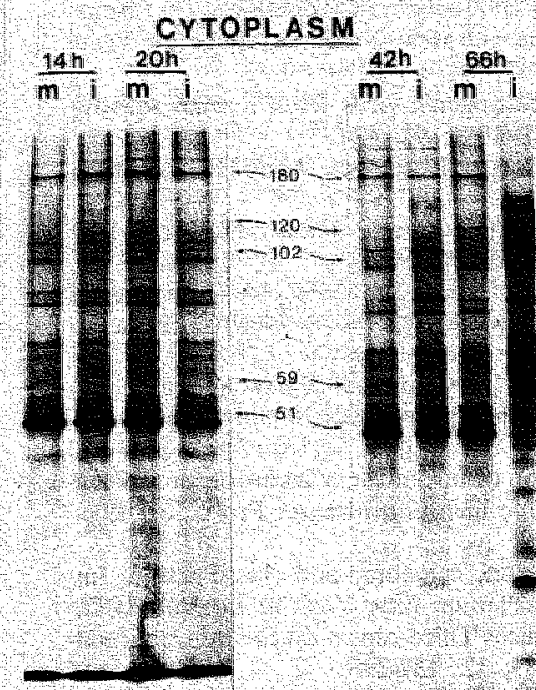

memock Intected Is RCMV infected

\section{.}

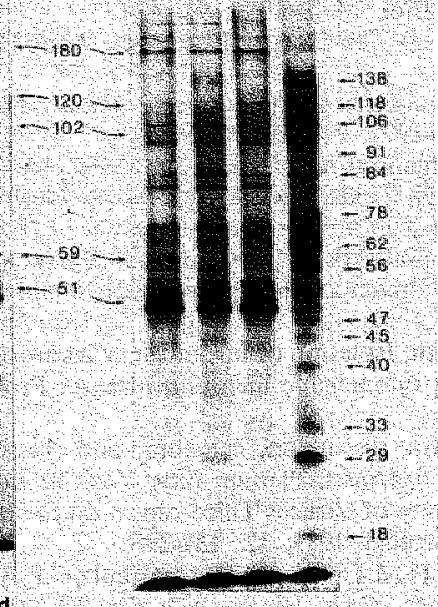

A

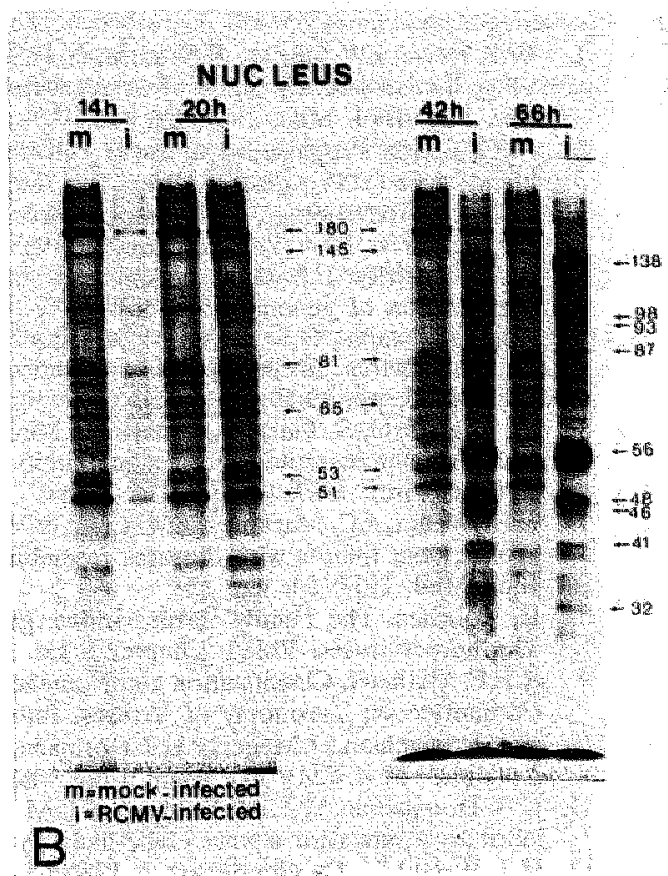

Time course appearance of RCMV-related proteins in cytoplasm fraction (A) or nuclear fractions (B) of REF cells. REF monolayers were mock-infected or RCMV-infected (MOI 1 PFU/cell). At times post-infection indicated, cells were pulse-labelled for 90 minutes with ${ }^{3 s} \mathrm{~S}$-methionine and further processed to prepare nuclear and cytoplasmic fractions as described in Methods. Samples of these fractions $(100,000 \mathrm{cts} / \mathrm{min}$ per lane) were submitted to PAGE and fluorography. 


\section{REFERENCES TO CHAPTER II}

1. W.P. Rowe, J,W. Hartley, S. Waterman, H.S. Turner RJ. Huebner. Cytopathic agent resembling human saliwary gland virus recovered from tissue cultures of human adenoids. Proc. Soc. Exp. Biol. Med. 1956; 92: 418.

2. M.G. Smith. Propagation of tissue cultures of a cytopathogenic virus from human salivary gland virus (SGV) disease. Proc. Soc Exp. Biol. Med. 1956; 92: 424.

3. F. Rapp. The Biology of Cytomegalowiruses in: The Herpeswinuses vol. 2. Ed. B. Roizman. Plenum Press New York \& London 1983.

4. B.A. Kilpatrick, E.S. Huang Human cytomegalovirus genome: Partial denaturation map and organization of genome sequences, I. Virol. $1977 ; 24,261-276$ :

5. R.L La Femina, G.S. Haymard. Structural organization of the DNA molecules from human cytomegalovirus. In: Animal virus genetics-BN Fields, R Jaenisch (eds.). New York Acad. Press 1980; Pp. 39.55.

6. M. Takekoshi, S. Ihara, S. Tanaka, F. Maeda-Takekoshi, Y. Watanabe. A new human CMV isolate has an invertible subsegment within its L-component producing eight genome isomers. J. Gen. Virol, 1987; 68, 765-776.

7. T.H Weller, J.C. Macanley, J.M. Craig \& Wirth. Isolation of intranuclear inclusion producing agents from infants with illnesses resembling cytomegalic inclusion disease. Proc. Soc. Exp. Biol. Med. 1957; 94: 4.

8. B. Roizman. The Family Herpesviridae: general discussion, taxonomy and classification. In: The herpeswiruses. Vol. I. Chapter I. Ed. B. Roizman. Plenum New York \& London 1982.

9. R.E.F. Mathews. Classification and Nomenclature of Viruses Third report on the international Committee on Taxonony of Viruses. Intervirology 1979; 12: 132-296.

10. C.A. Bruggeman, H. Meijer, P.H.J.Dormans, W.H.M. Debie, G.E.L.M.Grauls, C.P.A. van Boven. Isolation of a CMV-like agent from wild rats. Arch. Virol. 1982; 73: 231-241.

11. C.A. Bruggeman, W.H.M. Debie, G.E.L.M. Grauls, G. Majoor, C.P.A. van Boven. Infection of laboratory rats with a new CMV-like virus. Arch. Virol. 1983; 76: 189-199.

12. H.T. Wright Jr., Cr. Goodheart, A. Lielausis. Human Cytomegalovirus. Morphology by negative staining. Virology 1969; 23: 419-424.

13. H. Meijer, P.H.J. Dormans; J.L.M.C. Geelen, C.P.A. van Boven. Rat Cytomegalovirus: studies on the viral genome and the proteins of virions and nucleocapsids. Arch. Virol. 1986; 89: $45-46$.

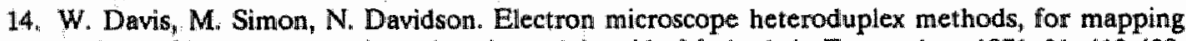
regions of base sequence homology in nucleic acids. Methods in Enzymology 1971; 21: 413-428.

1S. E.S. Huang, S.T. Chen, J.S. Pagano. Human Cytomegalovirus I Purification and characterization of viral DNA. J, Virol. 1973; 12: 1473-1481.

16. H. Meijer, J.C.F.M. Dreesen, C.P.A. van Boven. Molecular cloning and restriction endonuclease mapping of the rat cytomegalovirus genome. J. Gen. Virol. 1986; 67: 1327-1342.

17. C.A. Bruggeman, H. Meijer, F. Bosman, C.P.A. van Boven. Biology of rat cytomegalovirus infection. Intervirology $1985 ; 24: 1-9$.

18. C.A. Bruggeman, W.H.M. Debie, G.E.L.M. Grauls, C.P.A van Boven. Cytomegallowirus infection of rat endothelial cells in vitro. Arch. Virol. 1986; 87: 265-272.

19. C. Amadei, M. Tandy-Pamit, P. Couillin, N. Cabav, A. Bove, S. Michelson. Kinetic study of the development and localization of human CMV-induced antigens using monoclonal antibodies. Ann. Virol. 1983; 134E: $165-180$.

20. H. Meijer, P.H.J. Dormans, C.P.A. van Boven. Studies on rat cytomegalovirus induced structural and non-structural proteins present at (immediate) early and late times of infection. Arch. Virol. 1986; 89: 45-56.

21. S. Michelson-Fiske, F. Horodniceanu, J.C. Guillon. Immediate early antigens in human cytomegalovirus infected cells. Nature 1977; 270: 615-617.

22. J.E. Craighead, R.E. Kanich, J.D. Almeida. Non-viral microbodies with viral antigenicity produced in CMV-infected cells. J. Virol. 1972; 10: 766-775.

23. 1. Sarov, 1 . Abady. The morphogenesis of HCMN. Isolation and polypeptide characterization of Cytomegalovirus and dense bodies. Virology 1975; 66: 464-473.

24. M. Fiala R.W. Honess, D.C. Heiner, J.W. Heine Jr., J. Murnane, R. Wallace, L.B. Guze. CMVproteins I Polypeptides of virions and dense bodies. J. Virol. 1976; 19: 243-354. 
25. K.S. Kim, V. Sapienza, R.I. Carp, H.M. Moon. Analysis of structural polypeptides of purified human cytomegalovirus. J. Virol. 1976; 20: 604-611.

26. T. Albrecht, T. Cavallo, N.L. Cole, K. Graves. Cytomegallovirus. Development and progression of cytopathic effects in human cell culture. Lab. Invest. 1980; 42: 1-7.

27. D.H. Spector, L. Hock, J.C.Tamashiro. Cleavage maps for human cytomegalovirus DNA strain AD 169 for restriction endonucleases EcoRI, BgIII and HindIII. J. Virol. 1882; 42: 558-582.

28. J.L.M.C. Geelen, M.W. Weststrate. Organization of the human cytomegalovirus genome. In Herpesvirus DNA, 1982, pp. 325-343. Edited by Y. Becker. The Hague: Martinus Nijhoff.

29. B. Fleckenstein, I. Muller, J. Collins. Cloning of the complete cytomegalowirus genome in cosmids. Gene 1982; 18: 39-46.

30. A. Ebeling, G.M. Keil, E. Knust, U.H. Koszinowski. Molecular cloning and physical mapping of murine cytomegalovirus DNA. J. Virol. 1983b; 47: 421-433.

31. J.A. Mercer, J.R. Marks, D.H. Spector. Molecular cloning and restriction endonuclease mapping of the murine cytomegalovirus genome (Smith strain). Virology 1983; 129: 94-106.

32. M. Gao, H.C. Isom. Characterization of the guinea pig cytomegalovirus genome by molecular cloning and physical mapping. J. Virology $1984 ; 52$ : 463-477.

33. J.H. Wharton, B.E. Henry, D.J. O'Callaghan. Equine gytomegalovirus: cultural characteristics and properties of viral DNA. Virology 1981; 109: 106-119. 
THE DEVELOPMENT

AND CHARACTERIZATION

OF MONOCLONAL ANTIBODIES

AGAINST RAT CYTOMEGALOVIRUS

INDUCED ANTIGENS

\author{
J.H. Bruning \\ W.H.M. Debie \\ P.H.J. Dormans \\ H. Meijer \\ C.A. Bruggeman
}

Department of Medical Microbiology, University of Limburg, Maastricht, The Netherlands 


\section{A. SUMMARY}

In this paper the development of a battery of approximately 70 mouse monoclonal antibodies (McAb's) to RCMV-induced antigens and their characterization is discussed. Their reactivity with the whole scala of $c a .30$ virus specific proteins was tested in an enzyme linked immuno-assay (ELISA), whereas their ability to detect RCMV antigens at different localisations of in vitro infected cell-cultures and at different stages of infection was tested by immuno-fluorescence. In order to determine to what specific (viral) protein each of these McAb's was directed against, an immuno-precipitation technique was used, followed by SDS-PAGE. Furthermore, neutralising capacity of each McAb was tested, as well as the immunoglobulin class it belonged to. In this manner six categories of monoclonal antibodies were defined on basis of immuno-fluorescence aspects. The six categories identify most important viral structural proteins.

\section{B. INTRODUCTION}

Although cytomegalovirus is ubiquitous among patients with renal transplants, many questions remain about its clinical effects and importance. The modes of viral transmission with renal transplants, the triggers of reactivation of latent virus present within organ grafts or in recipients of these donor organs, and the central questions about its effects on renal graft function and survival are still poorly understood. Therefore, a rat cytomegalovirus (RCMV) was used in an animal transplantation model, in an effort to elucidate (some of) these questions. The rat cytomegalovirus probably closely resembles the human cytomegalovirus (HCMV; 4, 5, 6, 7, 8). In order to study more closely the localisation of the (latent) virus in the various organs, the spread of the virus after reactivation, and the role and localisation of the various viral proteins we decided to develop mouse monoclonal antibodies against the various viral structural proteins and virus-induced cell associated antigens. During cytomegalovirus infection, two categories of proteins appear in infected cells (1).

Firstly, proteins appear that are directly associated with the virus itself; the non-structural viral coded proteins, and the structural proteins composing the virion.

Secondly, the virus infection seems to stimulate the expression of some hostcell associated proteins that become so closely related to viral polypeptides that they are identified with them (14). Other cellular proteins are suppressed 
by the virus (14). The biological significance of these two categories and their role in viral replication, the development of anti-CMV immunity, as well as their possible role in the induction of renal allograft rejection is far from clear and should be investigated. Monoclonal antibodies to these two categories of proteins could be most helpful, and even essential, for such investigations.

\section{MATERIALS AND METHODS}

\section{Cells}

For the preparation of viral antigen extracts, for immunisation purposes, monolayers of rat embryonic fibrablasts (REF) were used. These monolayers were prepared as described before $(4,5)$, and used for virus replication at the third passage. Cells were grown in Eagle's minimum essential medium (MEM) supplemented with 10\% newborn calf serum (NCS) and maintained in Eagle's medium with $5 \%$ NCS. For virus growth, or to induce stationary G-o phase cells, the NCS concentration was reduced to $2 \%$.

Vinus

The rat cytomegalovirus (RCMV) strain used in previous studies (4-8) was propagated in confluent REF cells using a multiplicity of infection (MOI) between 0.1 and 2 PFU/cell.

\section{Preparation of antigen extracts for immunisation}

Three different preparation procedures for viral antigen extraction were used:

A. Supernatant of in vitro infected monolayers of REF:

Monolayers of REF grown in roller bottles $\left(1350 \mathrm{~cm}^{2}\right)$ were infected with RCMV with a MOI of 0.1 PFU/cell. After 3-4 days, by which time the monolayers showed a cytopathic effect (CPE) of $100 \%$, the supernatant was collected, centrifuged for 30 min. at 1500 r.p.m. ( $500 \mathrm{xg}$, Beckman table centrifuge $\mathrm{TJ} 6$ ) at $4^{\circ} \mathrm{C}$. The pellet was discarded and the supernatant was again centrifuged for $2 \mathrm{~h}$ at 18000 r.p.m. $(60,000 \mathrm{xg}$, Beckman ultra-centrifuge, sW 40 rotor $)$ at $4^{\circ} \mathrm{C}$. The pellet was resuspended in a small volume of phosphate buffered saline (PBS) and frozen and stored in small aliquots at $-70^{\circ} \mathrm{C}$ untill use. Total protein content was determined with protein assay of Biorad (3).

B. Tris-glycine NP40 extract of RCMV-infected sells was essentially prepared according to Vestergaard $e t$ al. (22): REF grown in roller bottles $\left(1350 \mathrm{~cm}^{2}\right)$ were infected as described above(A). Cells were harvested by vigourously shaking the roller bottles, followed by centrifuging this suspension at 1500 r.p.m. at $4^{\circ} \mathrm{C}$. The pellets were washed three times in PBS (500xg, $4^{\circ} \mathrm{C}$ ) and resuspended in TGN-buffer $(0,0038 \mathrm{M}$ Tris hydroxyamino-methan, $0,01 \mathrm{M}$ glycine, $1 \% \mathrm{v} / \mathrm{v}$ Nonidet $\mathrm{P} 40)$ and sonicated three times for 15 min at $0^{\circ} \mathrm{C}(\mathrm{Branson}$ sonifier $\mathrm{B} 30)$, output power 4. The homogenate was frozen and stored in small aliquots at $-7^{\circ} \mathrm{C}$ until use. Before use, the aliquots were quickly thawed and once again sonicated for $5 \mathrm{~min}$ at $0^{\circ} \mathrm{C}$, followed by centrifuging for $10 \mathrm{~min}$ at $4^{\circ} \mathrm{C}$ in an Eppendorf table centrifuge. Total protein contents were determined with a protein assay of Biorad (3).

C. Sonicated suspension of RCMV-infected REF (18): REF grown in roller bottles $\left(1350 \mathrm{~cm}^{2}\right)$ were infected as described before. Cells were harvested and washed as described under $B$. The cells were resuspended in a small wolume of PBS and sonicated three times for $15 \mathrm{~min}$ at $0^{\circ} \mathrm{C}$. The lysate was centrifuged for $30 \mathrm{~min}$ at $4^{\circ} \mathrm{C}$ at 2000 r.p.m. ( $850 \mathrm{~kg}$, Beckman TJ6 table centrifuge). The pellet was discarded and the supernatamt used as antigen for immunisation. One ml. of cell-sonicate thus prepared consisted of $1.5 \times 10^{8}$ disrupted cellis. 


\section{Purification of nucleocapsids}

REF cells grown in $150 \mathrm{~cm}^{2}$ Roux flasks, were infected with RCMV, using an MOI of $0.1 \mathrm{PFU} / \mathrm{cell}$. Upon appearance of advanced CPE (at 4 to 5 days pi.) cells were harvested and collected by centrifugation for $10 \mathrm{~min}$ at $800 \mathrm{r}, \mathrm{pm}$. and $4^{\circ} \mathrm{C}$. To release the nuelei, cells were treated with hypotone buffer $(1.6 \mathrm{mM} \mathrm{MgCl}, 6 \mathrm{mM} \mathrm{KCl}, 10 \mathrm{mM}$ Tris-HCl, $\mathrm{pH} 8.0,1 \mathrm{mM}$ dithiotreitol and $0.5 \%$ Nonidet p40) for $10 \mathrm{~min}$ at $4^{\circ} \mathrm{C}$. Nuclei were collected by centrifugation (1500 r.p.m. $10 \mathrm{~min}, 4^{\circ} \mathrm{C}$ ) and were carefully lysed with detergents to release RCMV nucleocapsids as previously described (Meijer, 1984). Nucleocapsids were recovered and purified as previously described (Meijer et al., 1984) except for a minor modification of the final purification step, to date: the crude nucleocapsid preparation was centrifuged through a discontinuous sucrose gradient $(20-40-60 \%$, w/v) made in TBS for $1 \mathrm{~h}$ at 32.000 r.p.m. and $4^{\circ} \mathrm{C}$ in a SW 40 rotor (Beckman). The purified nucleocapsids were colleced from the $40-60 \%$ interface, diluted with TBS and again centrifuged for $1 \mathrm{~h}$ and 32.000 r.p.m. and $4^{\circ} \mathrm{C}$. The pellet was then resuspended in the appropriate buffer for immunisation.

\section{Immunisation protocols:}

three different immunisation protocols were used:

First protocol:

- First immunisation: $10^{5}$ plaque forming units (PFU) of RCMV with complete Freund adjuwant (CFA) was injected intraperitoneally (i.p.) into Balb/c mice.

- Second and third immunisation:10 PFU of RCMV was injected i.p. with incomplete Freund's adjuvant (IFA), 14 and 28 days after the first immunisation.

- Fourth immunisation:intravenous (i.v.) injection of $100 \mu \mathrm{g}$ protein-content of antigen extract as described under $A$.

Second protocol: immunisation with antigen extract, prepared as described under B.

- First immunisation: $100 \mu \mathrm{g}$ protein-content of extract $\mathrm{B}$ i.p.,with CFA in Balb/c mice.

- 3 times a weekly booster with $100 \mu \mathrm{g}$ of extract B i.p. with IFA.

- Four weeks after last booster:100 $\mu \mathrm{g}$ of extract B i.w.

Third protocol: immunisation with antigen extract prepared as described under $C$.

- First immunisation: extract of $1,5 \times 10^{7}$ sonicated cells was injected with CFA i.p. into balb/c mice.

- Second immunisation: four weeks after first immunisation a same amount of antigen extract (without CFA) was injected i.v.

\section{Fusion protacol:}

3 days after the last i.v. booster, the spleens of the immunised Balb/c mice were aseptically removed. A single cell suspension was made in RPMI 1640 (Flow) with a Dounce homogeniser. Cells were washed three times in RPMI 1640 at $500 \mathrm{xg}, 4^{\circ} \mathrm{C}$. Fusion was done with the SP $2 / 0$ Ag14 mouse myeloma line in a ratio of spleen cells/myeloma cells of $2: 1$. A $40 \%$ solution of polyethylene glyeol 4000 (Merck) with $5 \%$ v/v dimethylsulfoxide (DMSO) in distilled water was used as the fusion agent. Hybrid cells were grown in Costar 3596 microtiter plates at a density of $10^{5}$ spleen cells/well. Peritoneal exudate cells (PEC) from Balb/c mice were used as feeder cells. Cells were maintained in Dulbecco's modification of minimal essential medium (DMEM, Flow) supplemented with $20 \%$ fetal calf serum (FCS, Gibco); $1 \%$ w/v non essential amino acids; $2 \mathrm{mM}$ L-glutamin, $4 \times 10^{-7} \mathrm{M}$ aminopterin; $10^{-4} \mathrm{M}$ hypoxanthine; $1.6 \times 10^{-5} \mathrm{M}$ thymidine and $1 \mathrm{mM}$ pyruvic acid. After four days of culture in a $\mathrm{CO}_{2}$ stove, $50 \%$ of the supematants in each well replaced with fresh medium. Aminopterin was omitted from the medium after 10 days. Screening of the supernatant for specific antibodies against RCMV was done 2-3 weeks after fusion, depending on the growth rate of the hybrid cell lines in the wells. 
As a first screening procedure an ELISA technique was used, as described in carlier publications $(5,6)$. In short, microtiter plates were coated with Tris-glycine NP40 extracts of RCMV and mock infected rat embryonic fibroblasts. Supernatants of hybridomas to be tested were transferred onto the wells and incubated for $2 \mathrm{~h}$, followed by incubation of the wells with peroxidaselabelled rabbit anti-mouse immunoglobulins for $1 \mathrm{~h}$. Finally the wells were incubated with orthophenylene dihydrochloride-substrate (OPD) for $20 \mathrm{~min}$. Between the subsequent steps the wells were washed with PBS/Tween 20. Absorbance wras measured at $492 \mathrm{~nm}$ with a multiscan (Titertek, Flow). Differences in absorbance greater than 0.07 between wellis with RCMV-and mock-infected antigen were considered positive.

\section{Expansion of productive clones; production of monoclonal antibody containing ascites}

Hybridomas producing antibodies to RCMV were cloned by limiting dilution and cocultured with $\mathrm{Balb} / \mathrm{c}$ peritoneal exudate cells. Clones which continued to produce significant titres of antibodies were expanded and injected into pristane primed Balb/c mice for propagation of monoclonal antibody producing tumours.

\section{Indirect immunofluorescence}

For detection of monocional antibodies reacting with RCMV late antigens (LA), REF grown to confluency on Labtek tissue culture chamber slides (Miles) were infected with. 1 PFU of RCMV per cell. At 3 days after infection cells were fixed with $3 \%$ paraformaldehycte in PBS and permeabilised with $0.05 \%$ Nonidet P40 (12). After washing in PBS monolayers were incubated with undiluted hybridoma supernatant or 1:200 to 1:1000 diluted ascites fluid. After 30 minutes incubation at $37^{\circ} \mathrm{C}$, in a humid atmosphere, monolayers were washed with PBS and stained with ITTC labelled rabbit anti mouse immuno-globulins (Nordic). After 30 minutes of incubation the monolayers were washed again and embedded in glycine-buffered glycerol $\mathrm{pH} 8.6$ (15). Monolayers were examined with a Zeiss fluorescence microscope. Mock infected monolayers served as a control. For examination of membrane fluorescence, unfixed infected and mock-infected REF were used. Incubation steps were performed at $4^{\circ} \mathrm{C}$ with $0.1 \%$ NaN3 in PBS. Monalayers were mounted in PBS-glycerol pH 7.4.

\section{Characterisation of antibody specificities:}

Immuno-precipitation reactions with extracts of RCMV infected and mock infected cells

Samples of all reactive monoclonal antibodies were used in immuno-precipitation reactions against extracts from RCMVinfecteded or mock infected cells labelled with ${ }^{35} \mathrm{~S}$ methionine, and the precipitated polypeptides were analyzed by sodium dodecyl sulphate polyacrylamide (SDS-PAGE) and autoradiography. We discriminated grossly between antibodies directed against virus coded late antigens ( $\mathrm{LA}$ ), and wirus coded immediate earty antigens (IEA) by using differently treated RCMV infected cell extracts.

\section{Preparation of ${ }^{35}$ S-labelled RCMV tate antigens}

REF cells grown in $150 \mathrm{~cm}^{2}$ Roux flasks, were infected with RCMV using an MOl of 1 PFU/cell. Four hours p.i. the culture medium was replaced by $20 \mathrm{ml}$ of a methionine deficient medium (Flow), containing $2 \% \mathbb{F C S}$ and $5 \mu \mathrm{Ci} / \mathrm{ml}^{35} \mathrm{~S}$-methionine. After 40 to $70 \mathrm{~h}$ radiolabelling (when cells showed advanced CPE), celis wrere harvested, washed twice in ice-cold PBS and resuspended in $1.5 \mathrm{ml}$ of a buffer containing $137 \mathrm{mM} \mathrm{NaCl}, 1 \mathrm{mM} \mathrm{CaCl}, 1 \mathrm{mM} \mathrm{MgCl}, 0.1 \%$ (w/v) Nonidet $\mathrm{P} 40$, $0.01 \%$ Na-azide, $1 \mu \mathrm{g} / \mathrm{ml}$ PMSF,10\% (w/v) glycerol and $20 \mathrm{mM}$ Tris-HCl pH 9.0 according to Bayliss (2). The cell suspensions were sonicated for $2 \times 20 \mathrm{sec}$ at $0^{\circ} \mathrm{C}$ and centrifuged for $30 \mathrm{~min}$ at $4^{\circ} \mathrm{C}$ 
in an Eppendorf centrifuge to remove cellular debris. The supernatant was frozen at $-70^{\circ} \mathrm{C}$ until use in the immuno-precipitation assay.

\section{Preparation of enriched $\left({ }^{35} S\right.$-labelled) RCMN immediate-early antigen}

REF cells grown in a $150 \mathrm{~cm}^{2}$ Roux flask, were infected with RCMV using an MOI of $4 \mathrm{PFU} / \mathrm{cell}$. During the absorption phase $(1.5 \mathrm{~h}$ ) and $6 \mathrm{~h}$ p.i. the culture medium (BME) contained cycloheximide ( $50 \mathrm{\mu g} / \mathrm{ml}$ ) to block protein synthesis. After $6 \mathrm{~h}$ cells were washed twice with TBS to remove cycloheximide and were then incubated for $18 \mathrm{~h}$ in methionine-deficient medium containing $25 \mathrm{FCS}$, $5 \mu \mathrm{Cl} / \mathrm{ml}^{35}$ S-methionine and $10 \mu \mathrm{g} / \mathrm{ml}$ actimomycin-D (to block de-novo transcription during radiolabelling). Such a procedure yields accumulation of the $85 \mathrm{kD}$ immediate-early antigen of RCMV (Meijer et al, 1986). After radiolabelling, cells were harvested and treated as described above.

\section{Immuno-precipitation of ${ }^{\text {s.s }}$ S-labelled RCMV antigens with monoclonal antibodies}

The supernatants containing the ${ }^{3 s}$ S-labelled RCMV antigens were first pretreated to lose protein contents that would react with normal mouse immunoglobulins, and possibly cross react with the McAb's to be tested. Supernatants were incubated with normal mouse serum (1:40 in PBS containing $2 \% \mathrm{FCS}$ ) during $1 \mathrm{~h}$ on ice, followed by incubation with protein-A-sepharose (Protein ACL-4BI, Pharmacia), $5 \mathrm{mg} / \mathrm{ml}$ supernatant,during $1 \mathrm{~h}$ at $4^{\circ} \mathrm{C}$. The protein-A-sepharose was then remowed by centrifugation in an Eppendorf centrifuge for $1 \mathrm{~min}$. One hundred $\mu \mathrm{l}$ of the pretreated cell lysate was mixed with $100 \mu \mathrm{l}$ hybridoma culture supernatant, incubated for $18 \mathrm{~h}$ at $4^{\circ} \mathrm{C}$, followed by adding $10 \mu \mathrm{l}$ of rabbit anti-mouse $\mathrm{IgG}(\mathrm{H}+\mathrm{L}), 2 \mathrm{mg} / \mathrm{ml}$. The mixture was gently vortexed and incubated for $30 \mathrm{~min}$ at room temperature. Protein-A-sepharose was added at a concentration of $5 \mathrm{mg} /$ $\mathrm{ml}$, followed by incubation for $30 \mathrm{~min}$ at room temperature. The protein-A immune-complexes were washed 3 times in TBS and once in distilled water (2). Samples were incubated for 2 min at $100^{\circ} \mathrm{C}$ in $20-50 \mu \mathrm{l}$ solution containing $60 \mathrm{mM}$ Tris- $-\mathrm{HCl}$ pH $7.0,10 \%$ glycerol, $5 \%$ B-mercaptoethanol, 0.0 $05 \%$ bromophenol-blue and $2 \%$ SDS. Electrophoresis was carried out during $16 \mathrm{~h}$ at $60 \mathrm{~V}$ in a $10 \%$ polyacrylamide-gel (11), followed by autoradiography using conditions previously described (14).

\section{Determination of antibody class and subclass of each of the McAb's}

Immunoglobulin-subclasses of the monoclonal antibodies were determined with a double antibody sandwich ELISA. Briefly, RCMV-and control*antigen coated wells of PVC ELISA plates were incubated with undiluted hybridoma supernatant or 1:1000 diluted hybridoma's ascites. After 2 hours incubation at $37^{\circ} \mathrm{C}$ and washing 3 times goat-anti-mouse immunoglobulin subclass antisera (Nordic), diluted as previously derermined by titration with known subclass antibodies (anti mouse $\operatorname{lgG}_{n_{0}} \mathrm{Ig}_{\mathrm{g}}$ -

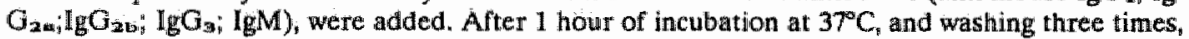
a 1:500 dilutation of peroxidase-conjugated rabbit-anti-goat immunoglobulin (Institut Pasteur) was added. After 1 hour of incubation, and washing 3 times, OPD substrate (see screening method of hybridomas) was added.The reaction was stopped with $\mathrm{H}_{2} \mathrm{SO}_{4}$ after $30 \mathrm{~min}$. Differences of $>0.100$ in absorbance between RCMV and control antigen wells were considered positive.

\section{RESULTS}

65 clones, selected for their reactivity in an ELISA, were used in this study. Their reactivity with the viral structural proteins and the RCMV-induced cellular products was tested by immuno-precipitation as described. In fig. 1 the polypeptides to which these McAb's are directed against are summarized and illustrated by the SDS-PAGE patterns of 7 representative McAb's. A comparison is made with the polypeptides that were defined as the structural pro- 
teins of RCMV virions as determined by Meijer et al. (14). As is shown, the whole scala of McAb's react with 9 polypeptides in the immuno-precipitation, of which 7 are viral structural proteins. Of all McAb's tested; 23 reacted with a $85 \mathrm{kD}$ protein, but at the same time also reacted with a scala of 2 or 3 other polypeptides,namely the 138,118 and $58 \mathrm{kD}$ polypeptides. Of the 28 structural proteins that could be recognized in mature virions the following polypeptides were recognized by the McAb's: $(29,42,55,58,112$ and $138 \mathrm{kD})$.

Fig. 1

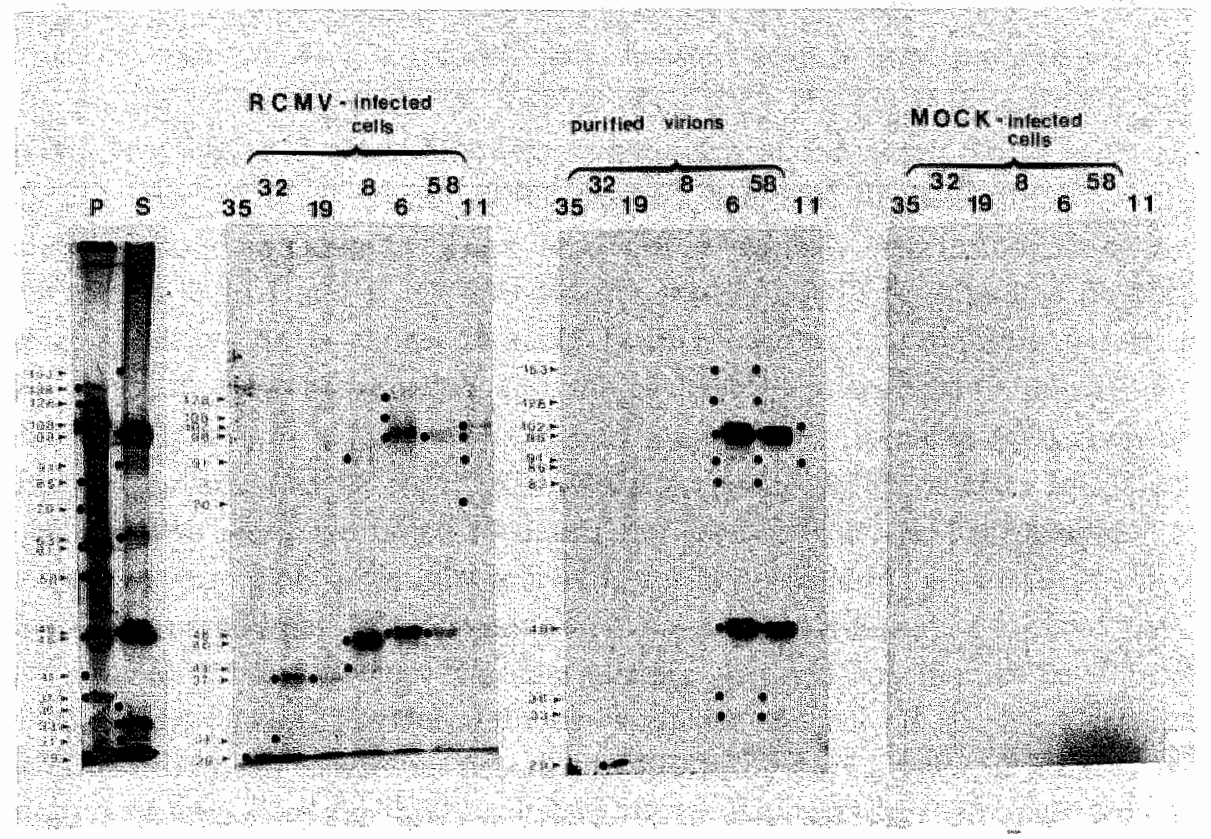

First column: SDS-PAGE patterns of purified extra cellular virions after 0.05 per cent NP 40 treatment; 8 per cent Acrylamide-gel. $P$ analysis of the pellet of the extract after centrifuging at $100.000 \mathrm{~g}$ for 1 hour. $S$ analysis of the supernatant of the extract after centrifuging at 100.000 $\mathrm{g}$ for 1 hour. Second column: SDS-PAGE patterns of immuno-precipitated polypeptides from extracts of RCMV infected fibroblasts. Third column: SDS-Page patterns of immuno-precipitated polypeptides from extracts of purified RCMV-virions. Fourth collu mn: SDS-PAGEpatterns of imumonoprecipitated polypeptides from extracts of mock-infected fibroblasts. 
Table 1

\begin{tabular}{|c|c|c|c|c|c|c|c|}
\hline $\begin{array}{l}\text { Detected viral } \\
\text { polypeptides }\end{array}$ & $\begin{array}{l}\text { thono- } \\
\text { clonals }\end{array}$ & $\begin{array}{l}\text { membrane } \\
\text { IF }\end{array}$ & $\begin{array}{l}\text { cytoplasm } \\
\text { staining }\end{array}$ & $\begin{array}{l}\text { nuclear } \\
\text { staining }\end{array}$ & $\begin{array}{l}\text { perinuct } \\
\text { staiming }\end{array}$ & $\begin{array}{l}\text { neutral- } \\
\text { izing } \\
\text { capacity }\end{array}$ & $\begin{array}{l}\text { anti- } \\
\text { body. } \\
\text { class* }\end{array}$ \\
\hline \multirow[t]{5}{*}{$29 \mathrm{kD}$} & 4 & + & + & - & - & - & $\mathbb{1}$ \\
\hline & 27 & + & + & - & * & - & 1 \\
\hline & 35 & + & + & - & - & - & $2 b$ \\
\hline & 36 & + & + & - & - & - & $2 b$ \\
\hline & 57 & + & + & - & - & - & 1. \\
\hline \multirow{4}{*}{$\begin{array}{l}37,31 \\
29 \mathrm{kD}\end{array}$} & 25 & - & + & - & - & - & 1 \\
\hline & 28 & + & + & - & + & - & $2 \mathrm{~b}$ \\
\hline & 30 & + & + & - & + & - & $2 \mathrm{a}$ \\
\hline & 32 & - & + & - & - & - & $2 a$ \\
\hline \multirow[t]{2}{*}{$37 \mathrm{kD}$} & 18 & + & + & - & + & - & $2 b$ \\
\hline & 19 & - & + & - & - & - & 1 \\
\hline \multirow{13}{*}{$\begin{array}{l}153,128 \\
108,98 \\
91,82 \\
48,36 \\
33 \mathrm{kD}\end{array}$} & 1 & + & + & - & + & + & 3 \\
\hline & 5 & + & + & - & + & + & $2 a$ \\
\hline & 6 & + & + & - & + & - & $2 b$ \\
\hline & 26 & + & + & - & + & - & 1 \\
\hline & 39 & + & + & - & + & - & 1 \\
\hline & 41 & + & + & - & + & - & 3 \\
\hline & 45 & + & + & - & + & - & 1 \\
\hline & 50 & + & $t$ & - & + & - & 1 \\
\hline & 55 & + & + & - & + & - & 1 \\
\hline & 59 & + & + & - & + & - & $\mathrm{M}$ \\
\hline & 61 & + & + & - & + & - & $2 \mathrm{a}$ \\
\hline & 64 & + & + & 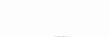 & + & - & 1 \\
\hline & 65 & + & + & $=$ & + & - & 1 \\
\hline \multirow{10}{*}{$\begin{array}{l}153,128 \\
98,91 \\
82,48 \\
36,33 \mathrm{kD}\end{array}$} & 7 & + & + & - & + & - & 1 \\
\hline & 9 & + & + & - & + & - & 1 \\
\hline & 13 & + & + & - & - & - & 1 \\
\hline & 17 & + & + & - & + & - & 1 \\
\hline & 20 & 4 & + & - & + & - & $\mathbb{1}$ \\
\hline & 22 & - & + & $=$ & $\#$ & - & $2 b$ \\
\hline & 38 & + & + & - wat & H & + & $2 \mathrm{a}$ \\
\hline & 70 & + & + & - & + & - & 1 \\
\hline & 72 & + & + & - & + & $\infty$ & $2 a$ \\
\hline & 73 & + & + & - & + & - & 1 \\
\hline \multirow{4}{*}{$\begin{array}{l}91,46 \\
41 \mathrm{kD}\end{array}$} & 8 & - & - & + & - & - & 1 \\
\hline & 10 & - & - & + & - & - & 1 \\
\hline & 14 & - & $=$ & + & - & - & 1 \\
\hline & 16 & - & - & + & - & $m$ & 1 \\
\hline $\begin{array}{l}102,98,91 \\
41 \mathrm{kD}\end{array}$ & 11 & + & + & - & - & - & 1 \\
\hline
\end{tabular}

- Antibody class: 1, 2a, $2 \mathrm{~b}$ and 3 refers to $\mathrm{IgG}$ subclasses; $M=I g M$ 
Table II: Neutralizing antibodies

\begin{tabular}{clc}
\hline Monoclonals & $\begin{array}{l}\text { detected viral polypeptides } \\
\text { in extracts of infected fibroblasts } \\
\text { (specificity) }\end{array}$ & $\begin{array}{c}\text { antibody } \\
\text { class* }\end{array}$ \\
\hline 1 & $153,128,108,98,91,82,48,36,33$ & 3 \\
2 & $?$ & 1 \\
5 & $153,128,108,98,91,82,48,36,33$ & $2 \mathrm{a}$ \\
38 & $153,128,98,91,82,48,36,33$ & $2 \mathrm{a}$ \\
58 & $?$ & 1 \\
\hline
\end{tabular}

- $1,2 \mathrm{a}$ and 3 refers to $\mathrm{IgG}$ subclasses.

Some of these McAb's are specifically directed against only one polypeptide $(29,46,50$ or $55 \mathrm{kD}$ polypeptides) or two $(102+112 \mathrm{kD}$ polypeptides $)$, the others reacting to 3 or 4 different polypeptides at the same time (Table I). On the basis of their specificity the McAb's could be divided into 7 groups as summarized in table $I$. Their neutralizing capacity was tested and summarized in table I and II. Of the McAb's tested, only 5 McAb's had neutralizing capacity. As is shown in table II there was no relationship between the antibody class or subclass and the neutralizing capacity. Of all 5 neutralizing McAb's, 2 belonged to the immuno-globulin subclass $\operatorname{IgG}_{1}$, two to class $\operatorname{IgG}_{2 a}$ and one to class $\operatorname{IgG}_{3}$. None appeared to be of class $\operatorname{IgG}_{2 b}$ or IgM. In two cases we failed to detect the specificity of the McAb either in a the Western blot or in the immuno-precipitation although these McAb's showed a marked neutralizing capacity. Each appeared to be a McAb of class IgG1. In all other instances the neutralizing $A b$ 's had specificities to several polypeptides (Table II). The antibody (sub)class of each of the McAb's was determined by an ELISA as described. The results are shown in table I. 30 McAb's belonged to the $\operatorname{IgG}_{1}$ subclass, 12 to class $\operatorname{IgG}_{2 \mathrm{~m}}, 7$ to class $\operatorname{IgG}_{2 \mathrm{~b}}$, 3 to class $\operatorname{IgG}_{3}$ and 3 to IgM. The ability of these McAb's to detect RCMV antigens at different locations of in vitro infected cells was tested with an indirect immuno-fluorescence test, as described and summarized in table I. The nuclear and cytoplasmic antigens were detected in paraformaldehyde-fixed monolayers of REF's, three days post in vitro infection, permeabilized with NP40. On unfixed cells, membrane antigens were detected in the same manner. The membrane fluorescence aspect was either finely granular and distributed over the whole surface of the cell, or polarized on one side of the cell. On fixed cells, the antigens detected with these monoclonals were situated either in the nucleus, the cytoplasm, or both. We discriminated five different patterns of fluorescence that are illustrated by the I.F. patterns of five representative McAb's in Table III; these five patterns are: diffuse non- 
granular staining of cytoplasm (class A), perinuclear staining combined with diffuse non-granular cytoplasmic staining (class B), perinuclear staining combined with fine granular cytoplasmic staining (class C), coarse granular cytoplasmic staining, combined with diffuse light non-granular cytoplamic staining (class D), strongly staining nuclear inclusion bodies combined with a diffuse light nongranular nuclear staining (class E). This is summarized in tables I and III. The division of the McAb's in six different categories is mainly based on this fluorescence pattern (cat. A to E). Category $F$ consists of McAb's that resulted after the fusion of mouse spleen cells that were specifically immunized with purified nucleocapsids in an effort to obtain McAb's directed against the basic strutural protein of $138 \mathrm{kD}$. Unfortunately, none of the Mc.Ab's of this category reacted with the $138 \mathrm{kD}$ protein whereas several McAb's of category $C$ did react with this main structural protein. These McAb's however (nrs. 1, 5, 6, 7, 29, 39, 45, 50,55, 61), though reacting with the $138 \mathrm{kD}$ protein, also reacted to a scala of three other polypeptides at the same time, namely with the 118,85 and $58 \mathrm{kD}$ polypeptide (see under discussion). As is shown here, four different polypeptides that appear in the cytoplasm of infected cells were detected by the McAb's $(138,118,56$ and 29 $\mathrm{kD}$ ), and two nuclear polypeptides (138 and $55 \mathrm{kD}$ ).

Table III

\begin{tabular}{|c|c|c|}
\hline Monoclonals & Category & Representative IF-pattern \\
\hline $\begin{array}{l}\text { (total 12) } 4,13,19,25,31,32,33 \\
34,35,36,48,57 .\end{array}$ & A & \\
\hline
\end{tabular}




\begin{tabular}{|c|c|c|}
\hline Monoclonals & Category & Representative IP-pattem \\
\hline (total 2) 2,3 & B & \\
\hline
\end{tabular}

(total 25) $1,5,6,7,17,18,20$, $21,22,27,29,30,38,39,45,46$, $47,49,50,55,56,58,59,61,64$
C

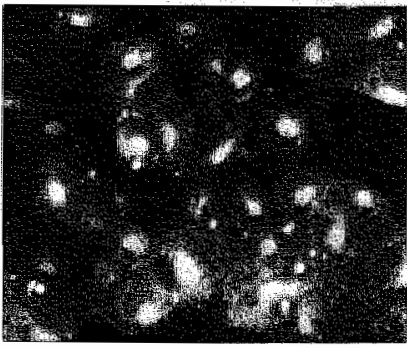

(total 8) $11,23,28,51,53,60$, 62,63 .
D

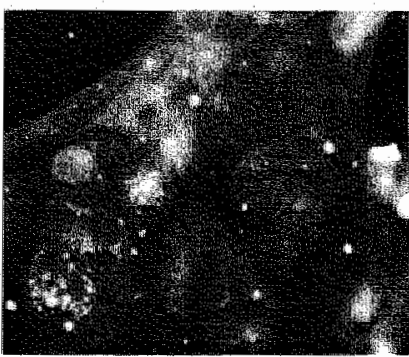

(total 5) $8,10,14,15,16$

E photo nr. 8

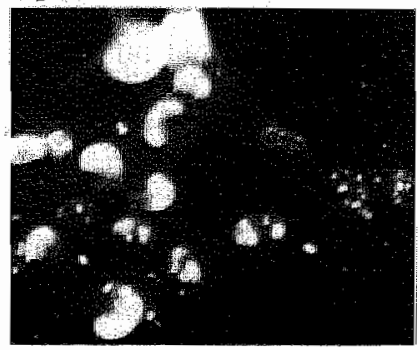

(total 4) $70,71,72,73$ 
though they specifically stained infected cells in the I.F.-procedure as discussed, or even exhibited neutralizing capacity. These monoclonal antibodies are summarized in Table IV.

Table IV: Monoclonal antibodies that failed to precipitate viral specific polypeptides significantly

\begin{tabular}{|c|c|c|c|c|}
\hline Monoclonals & $\begin{array}{l}\text { category of } \\
\text { IF staining }\end{array}$ & $\begin{array}{l}\text { membrane } \\
\text { IF }\end{array}$ & $\begin{array}{l}\text { neutralizing } \\
\text { capacity }\end{array}$ & $\begin{array}{l}\text { Antibody } \\
\text { class*" }\end{array}$ \\
\hline 31 & A & - & $\ldots$ & 1 \\
\hline 33 & & - & - & 1 \\
\hline 34 & & + & - & 1 \\
\hline 48 & & - & - & $2 \mathrm{a}$ \\
\hline 2 & B & + & + & 1 \\
\hline 3 & & + & - & 1 \\
\hline 7 & $\mathrm{C}$ & + & - & $\mathrm{M}$ \\
\hline 22 & & + & - & $2 b$ \\
\hline 29 & & + & - & $2 a$ \\
\hline 58 & & + & - & $\mathbb{1}$ \\
\hline 46 & & + & - & 1 \\
\hline 47 & & + & - & 1 \\
\hline 23 & $\mathrm{D}$ & + & - & $2 a$ \\
\hline 51 & & * & - & 3 \\
\hline 53 & & * & - & $2 b$ \\
\hline 60 & & + & - & $\mathbb{1}$ \\
\hline 62 & & + & - & $2 a$ \\
\hline 63 & & + & - & 2a \\
\hline 15 & $\mathbf{E}$ & - & - & 1 \\
\hline 71 & $\mathrm{~F}$ & $?+$ & $?$ & 1 \\
\hline
\end{tabular}

* $1,2 a$ and 3 refers to IgG subclasses.

\section{E. DISCUSSION}

The monoclonal antibodies produced and described in this report reacted in various cases with multiple virus-specific polypeptides (Table I and Fig. 1). The explanation for this phenomenon can be manyfold (19):

- Firstly: it may reflect the result of failure to separate hybridomas secreting antibodies with independent specificities.

- Secondly: it may represent the existence of shared epitopes on different polypeptides related to each other as precursors and products, therefore sharing sequence relatedness, and as a result identical antigenic determinants.

- Thirdly: it may reflect the existence of complexes between virus and host- 
- Thirdly: it may reflect the existence of complexes between virus and hostcell derived polypeptides that have not been separated by the antigen extraction procedures.

- Fourthly: it may represent the existence of shared epitopes on independent polypeptides due to limited regions of homologous structure in otherwise unrelated proteins.

- Finally: it may reflect aspecific non-immunological binding between antibodies and virus (or cell)-related proteins.

The first possibility could be excluded, since extensive further subcloning of the hybridomas secreting antibodies with multiple specificities did not result in the separation of clones with less or only one specificity. Furthermore, isoelectric focussing of these $\mathrm{McAb}_{\mathrm{C}}$ 's followed by transfer to nitrocellulose paper and immuno-detection of mouse Ig's did not reveal admixtures of one or more different McAb's either (adapted procedure from Towbin and Malamud, as described by Charlionet; 9 ; results not shown). The third possibility seems unlikely as well, because the molecular weights detected upon immuno-precipitation with these monoclonal antibodies correspond with molecular weights of polypeptides found in purified virions (Fig. 1) (14); no polypeptides were detected with these McAb's that were not also detected in purified virions. The last possibility mentioned cannot be fully excluded but seems unlikely since none of the control McAb's directed against irrelevant antigens such as E. coli (20) and human thyroglobulin (23) of identical immuno-globulin subclasses, failed to react with the same antigen extracts as used for immunizations in an ELISA, or in infected cells in an indirect immuno-fluorescence or immuno-peroxidase procedure (data not shown). The possibilities that remain are shared epitopes on different polypeptides, either because of their related ness to each other, or because of the existence of only limited numbers of possible tertiary structures of these epitopes. These findings are concordant with earlier publications on the production of herpesvirus Saimiri antibodies (19). As none of the monoclonal atibodies reacted exclusively with the basic structural polypeptide of $138 \mathrm{kD}$ it was decided to immunize Balb/c mice with purified nucleocapsids. The hybridomas that resulted from the fusion of primed spleen cells of these mice with the SP 2/0 Ag 14 myeloma cells, however, did not produce such monoclonal antibodies (category F, McAb's no's $70,71,72,73)$. Possibly the purification of the nucleocapsids resulted in fragmentation of the basic nucleocapsid protein, and consequently in McAb's with specificities for these fragments (to be published). On the other hand the isolation procedure of viral extracts for the immuno-precipitation may result in cleavage of the $138 \mathrm{kD}$ polypeptide as well. For instance this isolation 
procedure may result in the cleavage of the $138 \mathrm{kD}$ polypeptide in a $85 \mathrm{kD}$ polypeptide and various smaller residues, or a $58 \mathrm{kD}$ polypeptide and various smaller degradation products, both sharing the same antigenic epitope, and not being each others complement. This possibility is further suggested by the relatively large number of McAb's that react with both a $85 \mathrm{kD}$ and $58 \mathrm{kD}$ polypeptide and at the same time react with the $138 \mathrm{kD}$ polypeptide. The same could be the case with the $118 \mathrm{kD}$ polypeptide, being a degradation product of the $138 \mathrm{kD}$ polypeptide. The basic structural protein thus may be very labile and only when a large bulk of virus infected cells is used for the extraction of viral proteins in the SDS-PAGE analysis may some of the 138 $\mathrm{kD}$ proteins remain intact. As for the monoclonal antibodies that showed significant staining in the I.F. assay, but failed to show clear bands in the immuno-precipitation (Table IV), similar mechanisms as described above may play a role; some viral antigens present in infected cells may disintegrate upon isolation for the immuno-precipitation assay. Beside that, the viral epitopes stained in the I.F. by these monoclonal antibodies may be only recognized in their specific tertiary or quaternary structure (Neotopes) $(16,21)$, and their antigenicity is lost when their conformational uniqueness is lost as a consequence of the isolation procedure for the immuno-precipitation. We have demonstrated that only a limited number of the McAb's have neutralizing capacity. It is striking that these all show reactivity to several polypeptides. The observation could not be reversed; it did not automatically mean that when a McAb reacted to several polypeptides (or certain fixed combination e.g.), it also showed neutralizing capacity. No relationship could be detected between the antibody(sub)class and neutralizing capacity of a monoclonal antibody. None of the McAb's reacted solely with the 71 and 85 KD IE polypeptides (14) which could not, in fact, be expected because we immunized with RCMV antigen-extracts rich in structural antigens and, consequently, poor or devoid of IE antigens. Some McAb's reacted with a $85 \mathrm{kD}$ polypeptide, but it needs further investigation whether this is the same polypeptide as the IEA of $85 \mathrm{kD}$ molecular weight.This seems unlikely, however, because antibodies of each category (A to $E$; fig 1) reacted with a $85 \mathrm{kD}$ polypeptide so this might represent a cellular contaminant or a virus induce$\mathrm{d}$ cellular antigen. This last suggestion is supported by the fact that no 85 $\mathrm{kD}$ band could be detected upon SDS-analysis with mock-infected cell extracts. Therefore it was decided to produce new hybridomas with spleen cells of $\mathrm{Balb} / \mathrm{c}$ mice that were immunized with purified IEA's.

It is well known (7) that CMV may induce Fc-receptors for IgG in and on CMV-infected cells. With the McAb's described in this report, however, this did not cause significant background in the indirect immuno-fluorescence or 
immuno-peroxidase tests. Furthermore, mouse McAb's of the same (sub) class, and directed against irrelevant antigens $(16,21)$ did not shown any staining in infected cells. In preliminary testing of the McAb's for RCMV strain-specificity three other isolates of characterized RCMV were used. Most McAb's reacted with all four strains, but some showed strain specificity (to be published). The use of our McAb's in paraffin embedded and cryosections will be discussed in a following paper, in which the spread of the virus in various organs during an acute infection will be described.

Summarizing, the monoclonal antibodies described in this report appear to be very useful in the diagnosis of RCMV infection. The major viral strucural polypeptides are recognized by them. With the production of these McAb's we will have a powerful tool to study the biological significance of the appearance of RCMV-related proteins in vitro and in vivo. In our organ transplantation model it will hopefully prove to be of great significance to elucidate the questions about modes of transmission of RCMV infection, localisation of (latent) wirus within the organ grafts and possibly some questions about RCMV-induced rejection.

\section{ACKNOWLEDGEMENTS}

This work was supported by a grant from the Dutch Kidney Foundation (N.S.N.). We are grateful for the gift of the monoclonal antisera from Dr. M. de Baets and Dr. H. de Ree that served as control sera in these studies. We thank Dr. R. Theunissen for doing the IEF assays. 


\section{REFERENCES TO CHAPTER IW.}

1. C. Amadei, M. Tardy-Panit, P. Couillin, M. Coulon, N. Cabau, A. Bové, S. Michelson. Kinetic study of the development and localization of human $\mathrm{CMV}$-induced antigens using monoclonal antibodies. Ann. Virol. 1983; 134E; 165-180.

2. G.J. Bayliss, G. Deby, H. Wolf Animmunoprecipitation blocking assay for the analysis of EBV-induced antigens. J. Virol.Meth. 1983; 7; 229-239.

3. M.M. Bradford, A rapid and sensitive method for the quantitation of microgram quantities of protein utilizing the principle of protein-dye binding. Ann. Bicchem. 1976; 72: 248-254.

4. C.A. Bruggeman, H.Mejijer, P.H.J. Dormans, W.H.M.Debie, G.E.L.M. Grauls, C.P.A. Van Bowen. Isolation of a cytomegalovirus-like agent from will rats. Arch. Virol. 1982; 73; 231-241.

5. C.A.Briggeman, W.H.M. Debie, G. Grauls, G. Majoor, C.P.A. Van Boven. Infection of laboratory rats with a new CMV-likevirus. Arch. Virol. 1983; 76: 189-199.

6. C.A. Bruggeman, R. Meijez, W.H.M. Debie, P.M. FREDERIK, W. Engels, C.P.A. Van Boven. Biology of Rat cytomegalovirus infection. Intervirology 1985; $24: 1-9$.

7. C.A. Bruggeman, R. Reinders, W.H.M. Debie, P.M. Frederik, W. Engels, C.P.A. Van Boven. Demonstration of an IgG-Fcreceptor in rat cytomegalovirus infected cells. Archs. Virol. 1984; 81: 79.89.

8. H. Bruning, C.A. Bruggeman, C.P.A. Van Boven, P.J.C. Van Breda Vriesman. Passive transfer of CMV by cardiac and renal organ transplants in a rat model. Transplantation 1986; 41: 659-698.

9. R. Charlionet, C. Davrinche, C. Rivat. Subtypes ofthe human complement $C 3$ revealed by isoelectric focusing in immoblized $\mathrm{pH}$ gradients. Electrophoresis 1985; 6: 423-427.

10. St. De Fazekas, S. Groth, D. Scheidegger. Production of monoclonal antibodies. Strategies and tactic. J. Immun.Meth. 1980; 35: 1-21.

11. U.K. Laemmli. Cleavage of structural proteins during the assembly of the head of bacteriophage T4. Nature 1970; 227: 680-685.

12. $\mathbb{P}$. Laurila, I. Virtonen, J. Wartiovaara, S. Andsteinman. Fluorescent antibodies and lectins stain intracellular structures in fixed cells treated with non-ionic dettergent. J.Histochem. Cytochern. 1978; 26: 251-257.

13. H. Mejer, P. Dormans, J. Geelen, C.P.A. Van Boven. RCMV: Studies on the viral genome and the proteins of virions and nucleocapsid. J. Gen. Virol. 1984; 65:681-695.

14. H. Mejer, P.H.J. Dormans, C.P.A. Van Bowen. Studies on Rat Cytomegalovirus induced structural and non structural proteins present at (immediate-)early and late times of infection. Archs. Virol 1986; 82: in press.

15. R. Nakumura. Clinical laboratory concept and methods. In: Immunopathology 1974; 634. Little, Brown Co., Boston.

16. Neurath, and Rubin. Viral structural components asimmunogens of prophylactic value 1971: 87. S. Karger, Basel.

17. Oi and Herzenberg. Immunoglobulin producing hybrid cell lines. In: Selected methods in cellular immunology 1980, eds. Mishell and Shiigi. W.H. Freeman Publ., San Prancisco.

18. L. Perreira, M. Hoffman, D. Gallo, N. Cremer. Monoclonal antibodies to human CMV: Three surface membrane proteinswith unique immunological and electrophoretic properties speci. fycross-reactive determinants. Inf. Imm. 1982; 36: 924-932.

19. R.E. Randall, C. Newman, R.W. Honess. Isolation and characterization of monoclonal antibodies to structural and non-structural Herpesvirus Saimiri proteins. J. Virol. 1984; 52: 872-883.

20. J.M.De Ree, P. Schwillens, J.F. Van Den Bosch. Monoclonal antibodies that recognize the $P$ fimbriae F7, F72, F9 and F11 fron uro-pathogenic Escherichia coli. Inf. Immun. 1985; 50: 900-904.

21. M.A.V. Van Regenmortel. Plant wirus serology. Adv. Virus Res. 1966; 12: 207-271.

22. B.F. Vestergaard, O.J. Bjerrum, B. Norrild, P.C. Grarballe. Crossed Immuno-electrophoretic studies of the solubility and immunogenicity of HSV-antigens. J. Virol, 1977; 24: 82-96.

23. M. Zanetti, M. De Baets, J. Rogers. High degree of idiotypic cross-reactivity among murine monoclonal antibodies to thyro-globulin. J. Immunol. 1983; 131: 2452- 


\title{
CHAPTER V
}

NATURAL HISTORY OF RAT

CYTOMEGALOVIRUS INFECTION:

AN IMMUNOHISTOCHEMICAL STUDY

\author{
J.H. Bruning* \\ C.A. Bruggeman* \\ F. Bosman**
}

* Department of Medical Microbiology, University of Limburg,

P.O. Box 616 MD Maastricht, The Netherlands.

Department of Pathology, University of Limburg,

P.O. Box 616 MD Maastricht, The Netherlands.

Am. J. Pathol. 1988; submitted for publication 
In this paper we describe the natural course of rat cytomegalovirus (RCMV) infection, as studied in an inbred rat strain.

Virus titres in the various organs were determined, and virus-related antigens were localized immunohistochemically, using mouse monoclonal antibodies (MCA b's) against RCMV-induced antigens. Virus and/or virus-derived or induced antigens could only be detected during the acute phase of infection. After this period of approximately 2 weeks the animals became chronically or latently infected but virus could not be detected in any organ except for the salivary glands which remained virus positive for 6 weeks. In immunosuppressed rats ( $5 \mathrm{~Gy}$ of total body irradiation) the period during which infective virus could be detected in the spleen was prolonged up to 9 weeks. During the acute phase of infection no organ specific cells or structures contained viral antigens, except for an occasional Kupffer cell in the liver and type 2 pneumocytes in the lungs.

The virus appeared to have a preference for cells or tissues of mesodermal origin. Frequently mesothelial cells, fat cells, brown fat cells, and blood borne monocytoid cells were infected. Occasionally infected endothelial cells of capillaries and smaller lymph vessels were noted.

These studies show that the characteristic cytopathic effects (c.p.e.) on infected cells and/or the typical inclusion bodies may be absent in cells expressing viral antigens on their cell membrane, in their cytoplasm, and/or in the nucleus. These findings closely resemble the events in human cytomegalovirus (HCMV) infection. It is concluded that the rat model appears to be suitable to study the pathogenesis of cytomegalovirus related diseases.

\section{INTRODUCTION}

Cytomegalovirus (CMV) infections are widespread. Large scale investigations in the United States and Europe have revealed that approximately $50-80 \%$ of all individuals are infected (1-3). Most infections occur without clinical symptoms, but in immune compromised individuals manifest disease with more or less serious complications such as interstitial pneumonia or hepatitis may develop (3). In neonates a CMV infection is the most important cause of malformation and serious neurological defects e.g. retarded motor development (4) and sensomotor deafness $(5,6)$. In transplant patients the virus is responsible for 15 $20 \%$ of the mortality (7). Frequently, it is associated with diminished graft survival in renal transplants, although a causative correlation is doubtful (8). 
As with most Herpes viruses, once infection has been established, the virus remains in the body in a latent state. Little is known about the nature of these persistent infections, but there is circumstantial evidence that the latent CMV is harboured in various tissues such as kidneys, liver, salivary glands and cervix (9) and probably cells of leucocyte lineage (10). It is likely that latency is a more or less dynamic state with continuous reactivation and excretion of small amounts of infective virus $(9,11,12)$. This might be the cause of persistence of relatively high levels of circulating antiviral antibodies with occasional peaks (13) while these antibody levels as such have an important role in maintaining this latency (14). It would be most helpful to know the exact localisation of this latent virus and the cells in which the virus predominantly shelters, for it could lead e.g. to a better selection of donor grafts. Furthermore, it could open the possibility of selective treatment of infected grafts prior to transplantation.

In order to elucidate (some) of these questions we studied cytomegalovirus infection in a rat model using a strain of rat cytomegalovirus (RCMV) isolated and characterized in our department $(15,16,17)$. In an effort to determine the exact localisation of the (latent) virus and virus associated antigens within several organs, we used a panel of monoclonal antibodies (McAb's) (18) in an indirect immunoperoxidase assay (IPA) on paraffin embedded tissue sections.

\section{MATERIALS AND METHODS}

\section{Animals}

Inbred, Specific Pathogen Free (SPF) Lewis (LEW) rats were used. These rats were bred at Animal Care Facilities Services of the University of Limburg, Biomedical Centre, Maastricht The Netherlands.

\section{Winus and Infection}

The rat cytomegalovirus (RCMV) stock consisted of homogenates of salivary glands of infected laboratory rats as described in a previous report $(15,16)$.

Experimental infection of rats was established by intraperitoneal (i.p.) injection of $10^{5}$ PFU of RCMV as described before (15).

Wirus assays

Quantitative assays for infectious virus were performed by plaque assays, a modification of the method as used by Wentworth et al. (1970) and described by Bruggeman et al. (15, 16). In short, organ biopsies obtained at various times after infection were homogenised in a Ten Broeke grinder in minimal essential medium (MEM; Gibco) supplemented with $10 \%$ of newborn calf serum. This suspension $(10 \% \mathrm{w} / \mathrm{v})$ was further diluted ten times (w/v) and cultured on a monolayer of rat embryonic fibroblasts (REF) in a $\mathrm{CO}_{2}$ incubator under a final concentration of $0.25 \%$ agarose. 
The plaques were counted by microscopic observations at 7 days post infection after staining with methyleme blue, and were expressed in $10 \mathrm{Log} P F U / \mathrm{ml}$ of $10 \%$ (w/v) diluted organ suspensions. Cocultivation of single cell suspe nusions of spleens, lymph nodes and livers on REF was done in some instances as described before $(15,16)$. In gemeral the same procedure wras followed as described for the plaque assay except that for cocultivation intact viable cell suspensions were used instead of homogenates.

\section{Immunosippression}

Total body irradiation was administered at the indicated dose as previously described (19).

\section{Finxatives}

Tissue blocks of approx. $0,5-1 \mathrm{~cm}^{3}$ were washed in Phosphate Buffered Saline (PBS) and fixed overnight in a mixture of Periodate-Lysine-Paraformaldehyde (PLP) as described by McLean and Nakane (20).

\section{Histology}

Tissues of various origin were cut into small slices of approximately $0.5 \mathrm{~cm}$ in thickness, washed in PBS and fixed overnight in PLP-fixative. The tissue samples were then washed again in PBS, embedded in paraffin, and thin sections of $3-4 \mu \mathrm{m}$ were stained with haematoxylin and eosin.

\section{Monoclonal antibodies}

Mouse Monoclonall Antibodies (McAb's) against RCMV-induced antigens were manufactured in our laboratories as described before (18). These $\mathrm{McAb}$ 's detected most structural viral proteins as determined by Meijer et al. (17). In this study McAb's no."s 35, 8 and 58 were used. For standard screening procedures $\mathrm{MCAb}$ no. 35 suited best, being the antibody with strongest reactivity.

\section{Imununohistochemistry}

Thin tissue sections of approximately $4 \mu \mathrm{m}$ mounted on glass slides were deparaffinised, washed in $90 \%$ ethanol, followed by blocking endogenous peroxidase activity. This was accomplished by incubation in $100 \%$ muthanol with $0.3 \% \mathrm{H}_{2} \mathrm{O}_{2}$ for $30 \mathrm{~min}$.

The sections were then further rehydrated and washed in PBS, preincubated with PBS containing 2\% Bovine Serum Albumin (BSA) for $30 \mathrm{~min}$, followed by incubation for 60 min with one of our mouse MCAb's, washed again in PBS for 5 min, followed by incubation with biotinylated affinity purified sheep anti-mouse Ig (Amersham) 1:200 in PBS containing $2 \%$ BSA $_{r}$ washed again for 5 min in PBS followed by incubation with Biotin-Strepavidin-HRP-complex (Amersham) 1:400 in PBS containing $2 \%$ BSA for 30 min.

After washing again in PBS the sections were incubated for $10 \mathrm{~min}$ in OPD-substrate $0.05 \%$ in Tris-HCl buffer $\mathrm{pH} 7.4$; containing $0.002 \% \mathrm{H}_{2} \mathrm{O}_{2}$. The colour reaction was then stopped by washing in PBS, followed by counterstaining for 1 min in haematoxylin, dehydration and mounting in Entellan (Merck, Darmstadi, FRG). 
RESULTS

\section{Clinical observations}

Alterations in body weight and standard haematological values (haemoglobin, haematocrit, differential blood cell count) did not occur. Biochemical signs of altered renal function were not found (data not shown).

During the first week of infection marked splenomegaly was noted. The weight increase of the spleens was about $42 \%$ above the control weights. Sometimes some ascites was noted as well.

\section{Vinus titres}

During the first two weeks post inoculation the levels of infectious virus in the various organs were tested by plaque assay. These organs included the kidneys, spleen, thymus, lymph nodules, lungs, salivary glands, peripheral blood leucocytes (buffy coat) and brains (fig. 1a).

Some organs, e.g., thymus and lymph nodes, were tested for the presence of RCMV by co-cultivation on REF-monolayers as well (fig. 1b). It appeared that only during the first week post inoculation could infectious virus be detected. Later on, virus was detected only in the salivary glands (fig. 2). The titres appeared to be very low; spleens containing no more than approximately 2000 infective virus particles in the whole organ by plaque assay (Fig. 1a) or approximately 2000 virus containing cells by co-cultivation (Fig. 1b). This would amount to an incidence of one infected cell per 100,000 spleen cells. In the thymus the incidence appeared to be even lower: approximately 500 infected cells in the whole organ by co-cultivation, or one infected cell per $10^{6}$ thymic cells. In the kidney, highest levels of infective virus were reached on day 4 p.i., but in much lower quantity than in the spleen. Neither in the heart, nor in salivary glands, brain, peripheral blood cells or liver, could infective virus be detected.

\section{Immunohistochemistry}

Patterns of reactivity of the various monoclonal antibodies

It appeared that if one of our McAb's reacted with a certain infected cell, all or almost all of the McAb's reacted with this cell, although there remained differences in intensity and localisation. The patterns of reactivity of the various MCAb's were in agreement with our findings on in vitro infected fibroblasts, as was described in a previous report (17). 
Fig. 1: Vinustitres in various organs during acute RCMV infection as determinated by plaque assay and co-cultivation

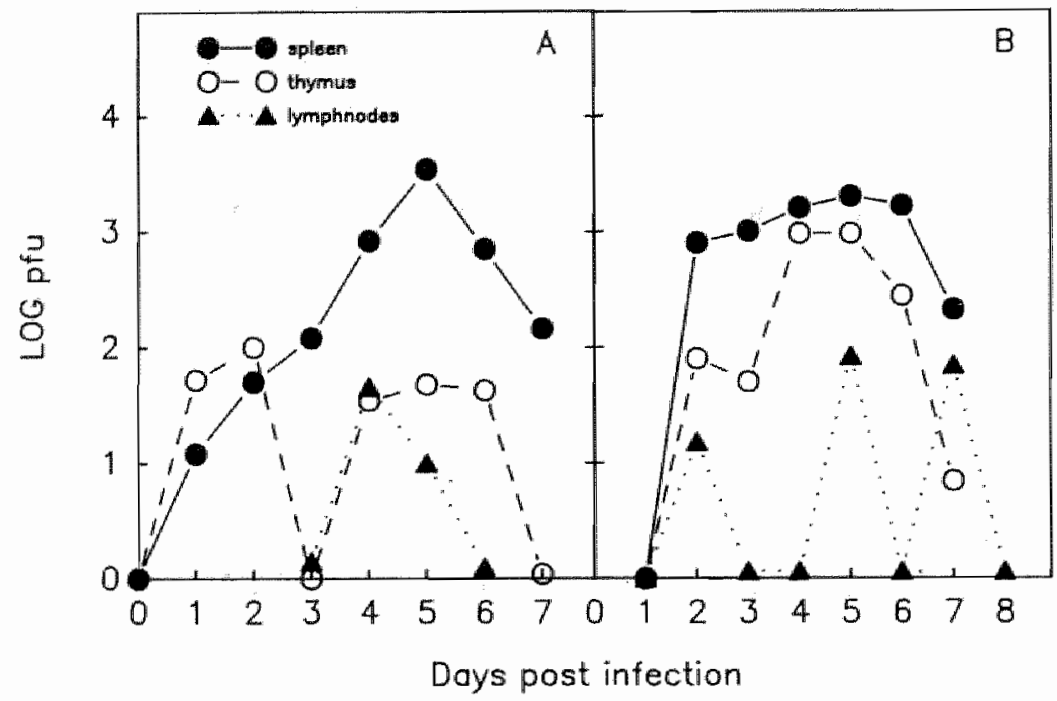

Lewis rats were inoculasted with $10^{5} \mathrm{PFU}$ of RCMV i.p. At various times post inoculation virus titres were determined in the warious organs mentioned. Comparison between plaque assay and co-cultivation in first week of infection.

Fig. 2: Virustitres in various ongans during acute RCMV infection in unmodified and $X$-irradiated Lewis rats (plaque assay)

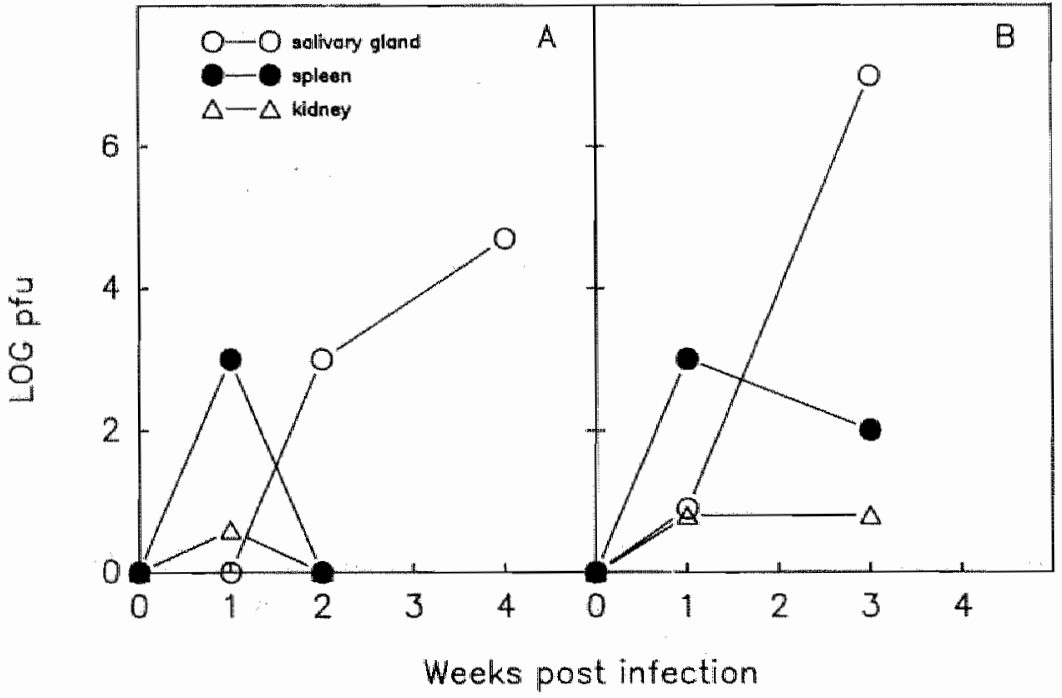

Idem; plaque assay in the first 4 weeks of infection in unmodified and $x$-irradiated (500 Rad TBi) Lewis rats. 
Fig. 3: Immuno-peroxidase staining aspect of 3 representative anti RCMV monoclonals

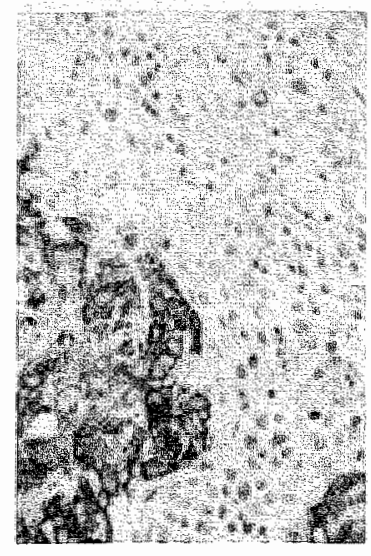

a. diffuse cytoplasmatic McAb no 35

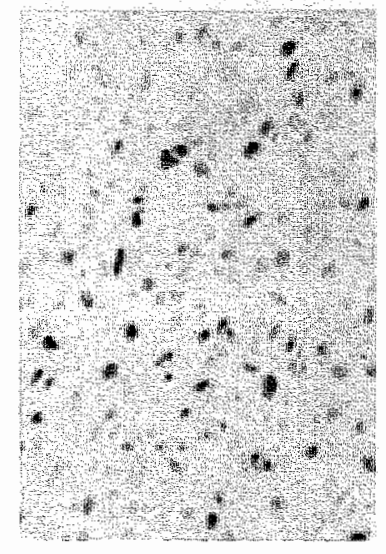

b. nuclear McAb no 8

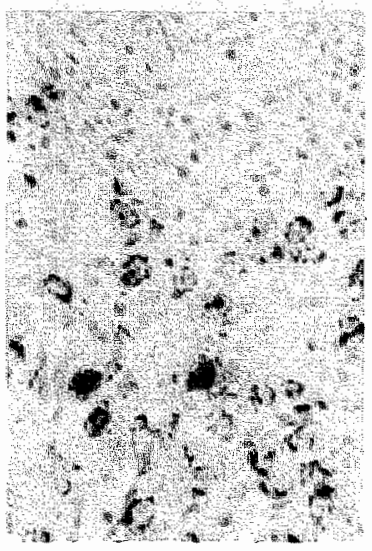

c. granular perinuclear $\mathrm{McAb}$ no 58

In Fig. 3 the patterns of immunoreactivity are illustrated in the spleen of an immunosuppressed lethally infected BN-rat.

$\mathrm{McAb}$ no. 35, directed against a 29 kiloDalton (kD) viral polypeptide (17) was suited optimally for standard screening purposes, being the antibody with the strongest reactivity. Never did this McAb fail to show reactivity in an infected cell when one of the other antibodies of our panel did react.

Kidney. In the kidney histopathological changes did not occur during the course of infection (Fig. 4a-c). Rarely, some immunoreactive cells were noted in the capillaries of some glomeruli, or in the vasa recta of the outer medulla. These cells showed irregularly shaped nuclei and resembled monocytes. In the capsule of the kidney intensely infected cells were frequently seen in the outer cell layers. These cells were spindle shaped and resembled fibroblasts. Sometimes large clusters of intensely immunoreactive cells were seen, mostly in the vicinity of neighbouring pads of perirenal fat. In these fat pads presumably endothelial cells associated with small lymph vessels were frequently infected. Furthermore occasionally intensely infected brown fat, and white fat cells were seen. 

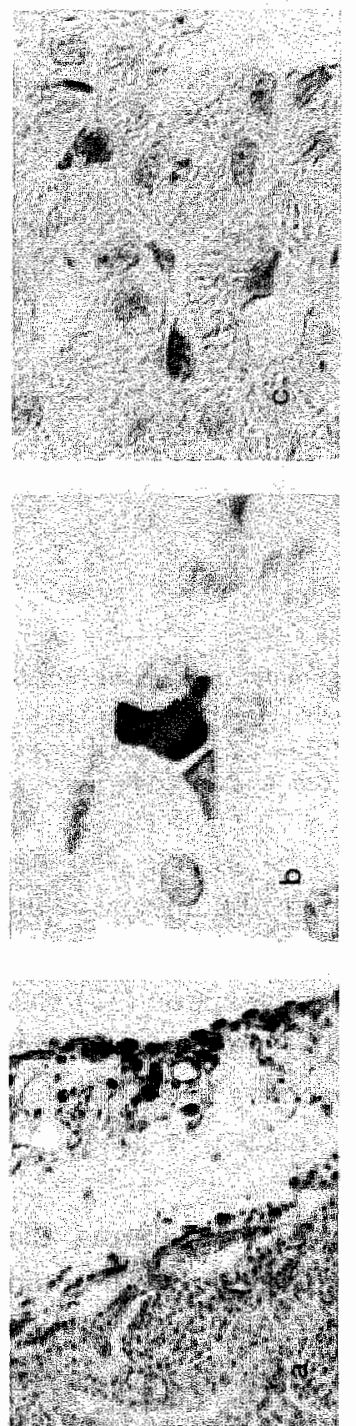

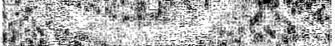
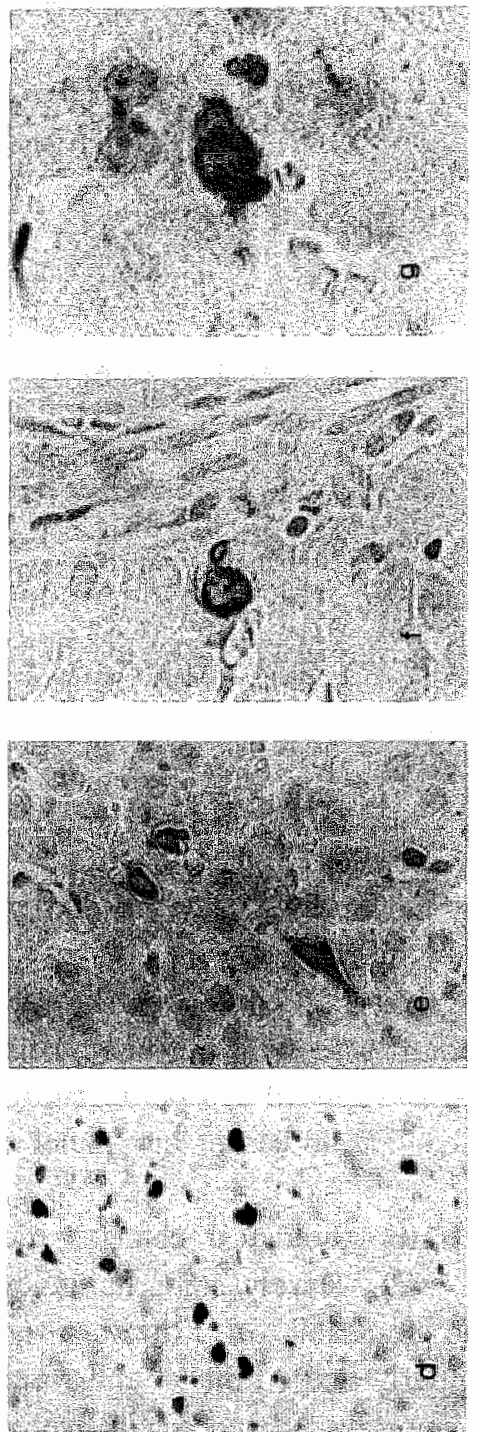
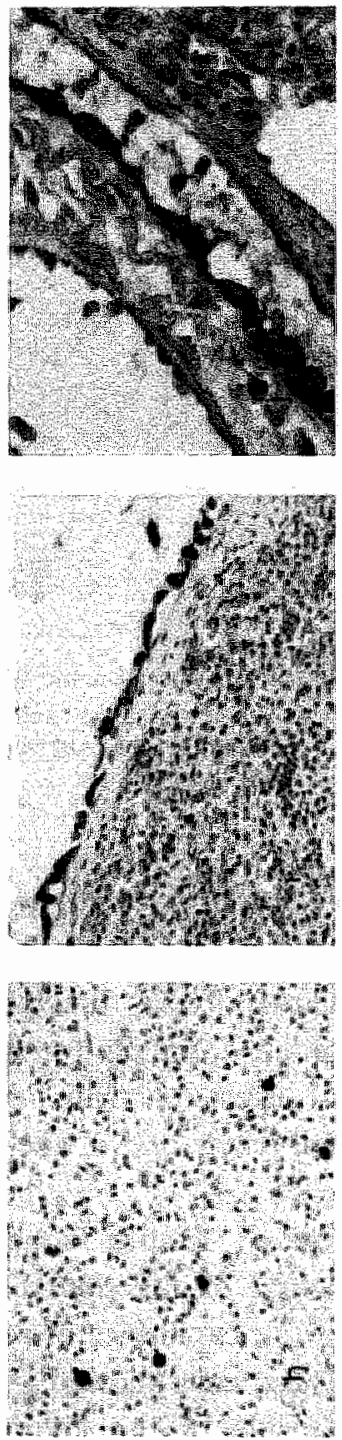

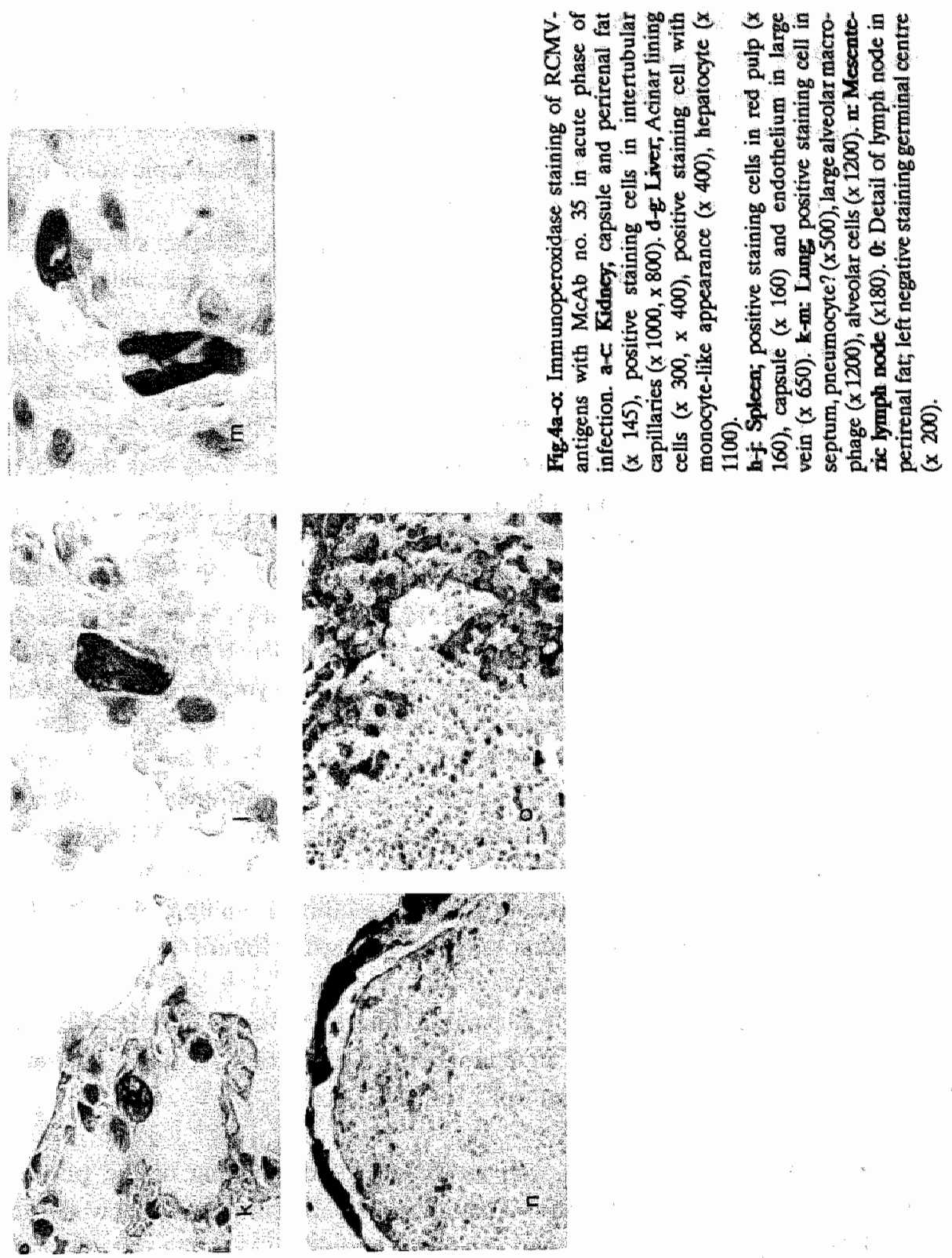
Heart. In the heart no histopathological alterations were observed. Viral antigens were not found in cardiomyocytes.

Rarely an immunoreactive cell resembling a monocyte was found in small intracardiac capillaries.

In the connective tissue single macrophages and occasional epicardial and pericardial mesothelial cells were infected.

Reactivity was not observed in aorta or vena cava. As for the surrounding pericardial fat the same observations were made as in the perirenal fat.

Liver. The liver showed a normal appearance and architecture (Fig. 4d-g). In the liver, diffusely scattered throughout the parenchyma, intensely immunoreactive cells were seen, resembling monocytes. Mostly these cells were situated in small blood vessels, but frequently immunoreactivity was also seen in the lining cells of the sinusoids, and occasionally also in single liver cells. The mesothelial lining occasionally contained infected cells.

Spleen. The spleen showed a normal appearance (Fig. $4 \mathrm{~h}-\mathrm{j}$ ). Scattered through the periarterial lymphocyte sheath (PALS) or perifollicular zones, red pulp immunoreactive cells, probably macrophages or lymphocytes, were found. The mesothelial lining frequently appeared to be infected.

The lungs and mediastinum. The lungs showed normal histology (Fig. 4k-m). In scattered alveoli some immunoreactive cells were noted, resembling type 2 pneumocytes or alveolar macrophages. In some septa extensive immunoreactivity occurred in macrophages, fibroblasts and mesothelial lining cells. In the oesophagus and trachea no immunoreactive cells were found.

Pancreas. The pancreas showed a normal architecture. In the fibrofatty tissue surrounding the acini, extensive immunoreactivity occurred. Acinar cells were seldom infected, infection of islet cells did not occur.

Peritoneum. Fibrofatty tissue as well as the mesothelial lining of the peritoneum were strongly virus positive. The infected cells frequently showed the characteristic cytopathic effects and inclusion bodies.

Thymus. In the thymus no reactivity occurred. In the capsule and the interlobular septa mesenchymal cells frequently contained viral antigens.

Lymph nodes. Lymph nodes were frequently found to be infected throughout the body (Fig. 4n-o). Here large quantities of intensely immunoreactive cells 
were seen in the marginal sinus, but not in the germinal centres. These cells showed extensive c.p.e. and were occasionally accompanied by multinucleated giant cells. The infected cells in the marginal zones comprised of macrophages; lymphocytes, endothelium, fibroblasts and fat cells.

\section{Infection in the immunocompromised hosts}

The course of infection was also studied in immunocompromised Lewis rats during 6 months. Virus titres in the various organs were regularly determined (Fig. 2).

In immunocompromised hosts the course of infection was somewhat prolonged and higher virus titres were reached in various organs. During the first week of infection almost all the organs tested contained infective virus. The virus titres depended on the depth of immunosuppression; the combination of $5 \mathrm{~Gy}$ and the inoculation of $10^{5}$ pfu of RCMV in 6 weeks old rats appeared to be lethal. In these rats a fulminant hepatitis developed. In those cases the spleen was heavily infected as well, with marked cellular necrosis (Fig. 3). The other organs tested showed no differences in comparison with the organs of unmodified infected rats in respect of immunohistochemical staining and virus titres three weeks after inoculation (Fig. 2). It was striking that the infection in the spleen was restricted to the areas outside of the germinal centres. The follicles remained virus free, despite of the lethality of infection (Fig. 3). The thymus, as in the non-immunosuppressed rats, remained free of viral antigens. Only in the surrounding fat, capsule and some septa were some heavily infected macrophages noted. Further fat cells and mesenchyme cells in the surrounding tissues were frequently infected as with the other organs as described before.

\section{DISCUSSION}

From our studies in the natural history of RCMV infections four important conclusions can be drawn.

Firstly, in the rat model used, CMV infections have as benign a course as in man. Clinically manifest disease never developed in normal healthy (adult) rats. The cytopathological propensity of the virus appears to be limited; only in areas of very severe infection, e.g. the marginal zone of lymph nodes, were the characteristic c.p.e. and/or inclusion bodies noted. This is in agreement with the findings in HCMV (21) and probably reflects a strong evolutionary 
adaptation of the virus to the host (3). In immunocompromised rats, however, (as in man) the virus may cause serious, even fatal disease. Fulminant hepatitis and splenitis may develop, as in recipients of bone marrow transplants in man.

The second important observation is that virai antigens can only be detected in the first week of infection. Later, when the infection becomes chronic or latent, viral antigens can no longer be detected in most organs.

It can be concluded that in these organs either the virus is eliminated or, more likely, turns into a latent state at an early stage. This last hypothesis is favoured by earlier findings that RCMV infection can readily be transferred with renal allografts obtained from latently infected donor rats (19). The only exception in this respect is constituted by the salivary glands in chronically infected rats, in which infective virus appears abundantly.

Thirdly, the cells that are infected in the acute phase of infection virtually all appear to be of mesodermal origin. The preference of the virus for these cells at present is not explained, but it is tempting to postulate intercellular differences in virus-specific receptors. It is noteworthy that many of the cell types that were found to be infected have phagocytic and/or antigen presenting functions.

Fourthly, we observed remarkable alternations in virus concentrations during the acute phase of infection (Fig. 1). This suggests a cyclic form of reproduction, possibly at other locations than in spleen or lymph nodes where the virus, after a short viraemic episode, may be merely trapped. If this last assumption is correct the location of primary reproduction site has still to be discovered.

As other investigators have found with HCMV (9) we were unable to detect latent infected cells with the aid of polyclonal or monoclonal antibodies in vivo. Possibly the reason for this failure is that latently infected cells only express IEA, as was found by Mocarski and Stinsky for HCMV (14), while we did not have specific antibodies directed towards these antigens available. On the other hand, polyclonal antiserum also failed to detect latently infected cells, and it can be expected that this serum contains antibodies directed against IEA, although in low quantities.

Furthermore, with HCMV, other investigators who did have available monoclonal antibodies directed against IEA could not detect latently infected cells either $(9,21,23)$.

Therefore another more plausible explanation for the difficulties in detecting latently infected cells might be that the viral genome, turning into latency, 
adapts a distinct tertiary configuration, which results in the exposure of different antigenic sites. These epitopes may not be recognized by McAb's directed against antigens of replicating virus. When replication ceases, no virus-related non-structural antigens are expressed. Since the "latent genome" probably is situated in the nucleus of infected cells, in vivo no antibodies are formed against the epitopes of this "latent genome".

The only possibility to produce McAb's specifically directed against this "latent genome" would be immunization with extracts of latently infected cells. Unfortunately this requires the availability of an in vitro model of latency that has not yet been developed.

We conclude that

1. Like HCMV, RCMV is poorly pathogenic but the virus may cause severe disease in immunocompromised individuals.

2. With anti RCMV-monoclonal Ab's virus, or virus-related antigens, can only be detected in the acute phase of infection. Latently infected cells are not recognised by these McAb's.

3. Virus replication may be a cyclic form of reproduction with sharp alternations in the first week post inoculation.

4. RCMV preferentially infects cells and tissues of mesodermal origin.

\section{ACKNOWLEDGEMENTS}

This work was supported by a grant from the Dutch Kidney Foundation (NSN) Grant no. C83-399. 


\section{REFERENCES TO CHAPTER V}

1. U. Krech. Complement-fixing antibodies against cytomegalovirus in different parts of the world. Bull. W.H.O. 1973; 49: 103-106.

2. C.A. Alford, S. Stagno, R. P. Pass, E.S. Huang Epidemiology of cytomegalovirus, pp. 159-71. In: A. Nahmius, W. Dowdle, R. Schenazi (eds.), The human herpes viruses. Elsevier Publishing $C_{0}$, Amsterdam, 1982.

3. M. Ho. Human cytomegalovirus infections in immunosuppressed patients, pp. 171-204. In: Cytomegalovirus, Biology and Infection. Current topics in infectious disease. Plenum Medical Book: Company, New York, 1982.

4. R.F. Pass, S. Stagno, G.J. Myers, C.A. Alford Jr. Outcome of symptomatic congenital infection: Results of long term longitudinal follow/-up. Pediatrics 1980; 66: 758-62.

5. C.S. Peckham, KS. Chin, J.C. Coleman, K. Henderson, R. Hurley, P.M. Price. Cytomegalovinus infection in pregnancy. preliminary findings from a prospective study. Lancet 1983; 1: 1352-55.

6. J.F. Bale. Human cytomegalovirus-infection and disorders of the nervous system (review). A.rch. Neurol. 1984; 41 (3): 310-320.

7. B. Lonnquist, O. Ringden, B. Wahren, G. Gahrton, G. Lundgren. Cytomegalovirus infection associated with and preceding chronic GvH-disease. Transplantation 1984; 38 (5): 465-468.

8. J.H. Bruning, C.A. Bruggeman, P.J.C. van Breda Vriesman. The effect of cytomegalowirus infection on renal allograft function and survival in a rat model. (submitted for publication).

9. M.C. Jordan. Latent infection and the ellusive cytomegalovirus. Rev. Inf. Dis. 1983; 5: 205-215.

10. G.P.A. Rice. Cytomegallovirus infects human lymphocytes and monocytes: virus expression is restricted to immediate-early gene products. Proc. Natl. Acad. Sci. USA 1984; 81: 6134.

11. B. Roizman. In: M. Pollard (ed.), Perspectives in Virology. Harper and Row, New York 1965, pp. 283-304.

12. J.C. Waner, T.H. Weller, S.V. Kevy. Patterns of cytomegaloviral complement-fixing antibody activity. A longitudinal study of blood donors. J. Inf. Dis. 1973; 127: 538-543.

13. D.W. Reynolds, S. Stagno, T.S. Hosty, M. Tiller, C.A. Alford. Maternal Cytomagalovirus excretion and perinatal infection. New Engl. J. Med. 1973; 289: 1-5.

14. E.S. Mocarski, M.P. Stinsky. Persistence of the cytomegalovirus genome in human cells. J. Virol. 1979; 31: 761-775.

15. C.A. Bruggeman, H. Meijer, P.H.J. Dormans, W.H.M. Debie, G.E.L.M.Grauls, C.P.A. van Boven. Isolation of a cytomegalovirus-like agent from wild rats. Arch. Virol. 1982; 73: 231-241.

16. C.A. Bruggeman, W.H.M. Debie, G. Grauls, G. Majoor, C.P.A. van Boven. Infection of laboratory rats with a new CMV-like virus. Arch. Virol. 1983; 76: 189-199.

17. H. Meijer, P.H.J. Dormans, J.L.M.C. Geelen, C.P.A. van Boven. Rat cytomegalovirus: studies on the viral genome and proteins of virions and nucleocapsids. J. Gen. Virol. 1984; 65: 681-695.

18. J.H. Bruning, W.H.M. Debie, P.H.J. Dormans, H. Meijer, C.A. Bruggeman. The development and characterization of monoclonal antibodies against rat cytomegalovirus-induced antigens. Arch. Virol. 1987; 94: 55-70.

19. J.H. Bruning, C.A. Bruggeman, C.P.A. wan Boven, P.J.C. vam Breda Vriesman. Passive transfer of cytomegalovirus by cardiac and renal organ transplants in a rat model. Transplantation 1986; 41: 695-698.

20. I.W. McLean P.K Nakane. Periodate-lysine paraformaldehyde fixative. A new fixative for immunoelectron microscopy. J. Histochem. Cytochem. 1974; 22: 1077.

21. D. Meyerson, R.C. Hackman, J.A. Nelson, J.C. Ward, J.K. McDougall. Widespread presence of histologically occult cytomegalovirus. Hum. Pathol. 1984; 15 (5): 430-439.

22. D.J. Winston, R.P. Gale, D.V. Meyer, L.S. Young. Infectious complications of human bonemarrow transplantation. Medicine 1979; 58: 1-31.

23. J.G. Stevens. Latent characteristics of selected herpes viruses. Adv. Canc. Res. 1978; 26: 227 256. 


\title{
CHAPTER VI
}

\section{PRESENCE OF CYTOMEGALOVIRUS IN BROWN FAT STUDY IN A RAT MODEL}

\author{
C.A. Bruggeman* \\ J.H. Bruning* \\ G. Grauls*
}

A.E.J.M. van den Bogaard*

F. Bosman**

* Department of Medical Microbiology, University of Limburg, P.O. Box 616, 6200 MD Maastricht, The Netherlands. Department of Immunology, University of Limburg, P.O. Box 616, 6200 MD Maastricht, The Netherlands. 
Cytomegalovinus infection of laboratory rats resulted in the appearance of virus and viral antigens in interscapular and periaortic brown fat.

This appearance was limited to the acute infection (first week post infection) and was dependent on the route of inoculation.

In our study virus could only be detected in subcutaneous brown fat in young rats (till 4 weeks of age), whereas in the deep brown fat (periaortic region) no age dependency was found.

Infection with cytomegalovirus (CMV) is common all over the world. Although most infections occur without clinical symptoms, in immuno-compromised patients and transplant recipients clinically manifest disease frequently developed (1).

For the study of the course of the CMV infection animal models have been shown to be of great value $(2,3)$. In earlier report from our laboratory, we described the isolation and characterization of a CMV isolated from wild rats (4). The virus has typical CMV-characteristics (5-7) and closely resembles to the human virus in its interaction with cells $(4,8,9)$ and antiviral agents (10-12). Infection of laboratory rats with rat CMV (RCMV) results in a generalised infection without clinical symptoms (13). In immunosuppressed rats the infection runs a severe course (14).

After an acute infection, RCMV persists in the host and can be transferred by kidney transplantation (14). Studies on the course of the acute RCMV infection revealed that during the first weeks post inoculation small amounts of infectious virus could be detected in heart, spleen, kidneys, lungs, liver and thymus.

By standard techniques such as immunofluorescence and immunoperoxidase did not detect virus-infected cells in these organs (13).

In our search for its presence on several occasions we found viral proteins in brown fat at different sites.

In this communication we report further observations concerning the localisation of viral proteins during acute infection. The detection of virus and/or viral antigens in the brown fat cells in the rat model may have implications for the elucidating the course of CMV infections in man.

RCMV was maintained in our laboratory by serial passage in inbred SPF Lewis (Lew) and Brown Norway (BN) rats (Centralised Experimental Animals Facilities, University of Limburg, Maastricht, The Netherlands) followed by salivary gland harvest as described before (13). The stock virus had a titer of $10^{6} \mathrm{PFU} / \mathrm{ml}$. 
Table 1: Presence of virus and viral antigens in brown fat cells from RCMV infected rats."

\begin{tabular}{|c|c|c|c|c|c|c|}
\hline \multirow{2}{*}{$\begin{array}{l}\text { Rat's } \\
\text { age }\end{array}$} & \multirow[b]{2}{*}{$\begin{array}{l}\text { Inoculation } \\
\text { route }\end{array}$} & \multirow[b]{2}{*}{$\begin{array}{l}\text { Days } \\
\text { p.i. }\end{array}$} & \multicolumn{4}{|c|}{ Viris detection } \\
\hline & & & $\begin{array}{l}\text { Interscapular } \\
\text { on REF } \\
\text { (A) }\end{array}$ & $\begin{array}{l}\text { brown fat } \\
\text { IPO } \\
\text { (B) }\end{array}$ & $\begin{array}{l}\text { Periaontic brown } \\
\text { on RBF } \\
\text { (A) }\end{array}$ & $\begin{array}{l}\text { fat } \\
\text { (B) } \\
\text { (B) }\end{array}$ \\
\hline \multirow[t]{3}{*}{$3 \mathrm{~d}}$. & & 5 & - & - & + & + \\
\hline & i.p. & 7 & - & - & & + \\
\hline & i.p. & 90 & $\mathrm{ND}^{\mathbf{B}}$ & $\mathrm{ND}$ & $\mathrm{ND}$ & - \\
\hline \multirow[t]{2}{*}{$3 \mathrm{~d}}$. & s.c. & 5 & $+(+)^{c}$ & + & - & - \\
\hline & s.c. & 7 & + & + & + & + \\
\hline \multirow[t]{3}{*}{3 wks. } & i.p. & 7 & ND & - & + & + \\
\hline & i.p. & 26 & & - & & - \\
\hline & i. $p_{n}$ & 80 & $-(-)^{e}$ & ND & $\mathrm{ND}$ & \\
\hline \multirow[t]{2}{*}{3 wks. } & s.c. & 7 & + & + & + & - \\
\hline & s.c. & 20 & $-(-)^{c}$ & ND & ND & - \\
\hline 5 wks. & i.p. & 7 & - & $\mathrm{ND}$ & +8 & + \\
\hline 10 wks. & s.c. & 7 & - & - & ND & + \\
\hline 18 wks. & i.p. & 7 & $-(-)^{c}$ & ND & ND & + \\
\hline
\end{tabular}

- The rats were infected with $10^{5}$ PFU RCMV. Virus was detected by inoculation of the brown fat cell suspension on REF monolayers (A); virall antigens were detected by Immunoperoxidase (IPO) technique (B)

- ND: not determined.

- ( ): results of cell transfer experiments.

Noninfected salivary gland homogenates were prepared in a similar manner. Virus stocks were titrated using a plaque assay (4) and were stored at $-80^{\circ} \mathrm{C}$ until use. Infection of rats

was established by intraperitoneal (i.p.) inoculation with $10^{3}$ or $10^{5}$ PFU RCMV or the same amount subcutaneously (s.c.) on the back of the animals, depen ding on the experiment. These animals were maintained in separate cages in our animal facilities, sacrificed at several days post inoculation (Table 1), and viral antigens in brown fat cells was examined. In addition, the cell transfer technique was used for the detection of infectious virus when indicated (see Table 1).

Brown fat, obtained from the more peripherally situated areas, such as the interscapular area, which contains the bulk of brown fat in rats (15), and from the more deeper deposits of brown fat situated along the aorta, was examined for virus. 
At various intervals post infection (p.i.) rats were killed by ether inhalation and exsanguination. At least 4 rats were examined at each interval. Interscapular and periaortic brown fat was dissected, cut into small pieces and homogenised in a Ten Broecke grinder. A $10 \%$ (w/v) suspension was prepared as described previously (13) and inoculated onto a confluent monolayer of rat embryonic fibroblasts (REF) for a plaque test.

A suspension of brown fat cells isolated from one rat was inoculated s.c. into an immunosuppressed (by X-irradiation) (14) rat. One week after the cell transfer, the interscapular brown fat was assayed for the presence of infectious virus by plaque assay on REF monolayers. Histological examination of brown fat of infected rats by routine methods showed an inflammatory infiltrate of mononuclear cells with numerous macrophages. In addition cytomegalic cells were encountered (Fig. 1).

Viral antigens were detected by our immunoperoxidase technique as described previously (13). To detect RCMV antigens hyperimmune RCMV-antiserum prepared in rats or monoclonal antibodies (no's 8, 35 and 70) prepared in mice were used (unpublished data). Monoclonal antibody clone no. 8 bound to nuclear antigenic sites and reacted with the $48 \mathrm{kD}$ protein of the virus, whereas clone no. 35 reacted with the $29 \mathrm{kD}$ protein of the virus and bound to cytoplasmic antigenic sites and clone no. 70 reacted with the major structural protein $(138 \mathrm{kD})$ of the virus (6).

The results of the detection of viral antigens by the immunoperoxidase technique are summarised in Table 1. Representative photomicrographs of brown fat cells containing viral antigens are shown in figure 2.

Using virus isolation techniques (inoculation of cell suspensions on REF monolayers and cell transfer experiments) and techniques for viral antigen detection (immunoperoxidase) in the brown fat of rats of different ages inoculated with RCMV (using different routes) the following results were obtained: In the interscapular brown fat of rats of different ages infected i.p. with RCMV, no virus or viral antigens were detected, indicating that the virus did not reach the interscapular brown fat area by this inoculation route. In contrast in rats infected s.c. virus reached the interscapular area. Virus and viral antigens were detected in young (3-day until 3-week old) rats during the first week p.i. Thereafter the virus and viral antigens were no longer detectable in the interscapular brown fat. When older rats $(5,10$ and 18 weeks old) were inoculated s.c. with RCMV, no virus or viral antigens were detectable in the interscapular brown fat. The amount of virus $\left(10^{3}\right.$ to $\left.10^{5} \mathrm{PFU} / \mathrm{rat}\right)$ inoculated had no effect on the results obtained. No differences between Lew and $\mathrm{BN}$ rats were observed in any of our experiments. 
Fig. 1: Brown fat, CMV infected rat. Note diffuse infiltrations of the tissue with neturophil granulocytes and macrophages (HE, $\times 120)$.

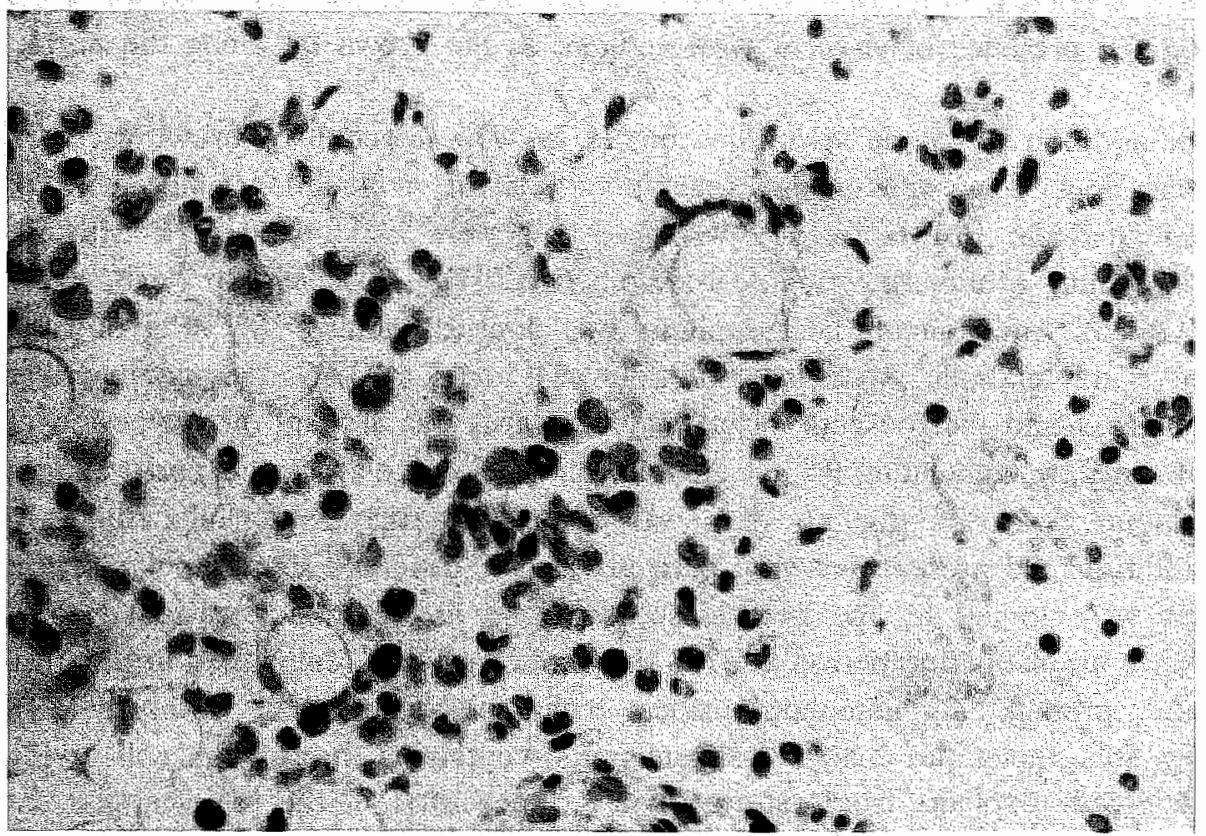

Fig. 2 (a) Brown fat, $C M V$ infected rat. Immunocytochemical demon-stration of viral antigens. Note intense staining of nuclei and cytoplasm of several fat cells (indirect inmmunoperoxidase with haematoxylin counterstain; $x$ 500). (b) Brown fat, CMV infected pat. Negative control (indirect immunoperoxidase with non CMV specific antibody, haematoxylin counterstain, $x 300$ ).

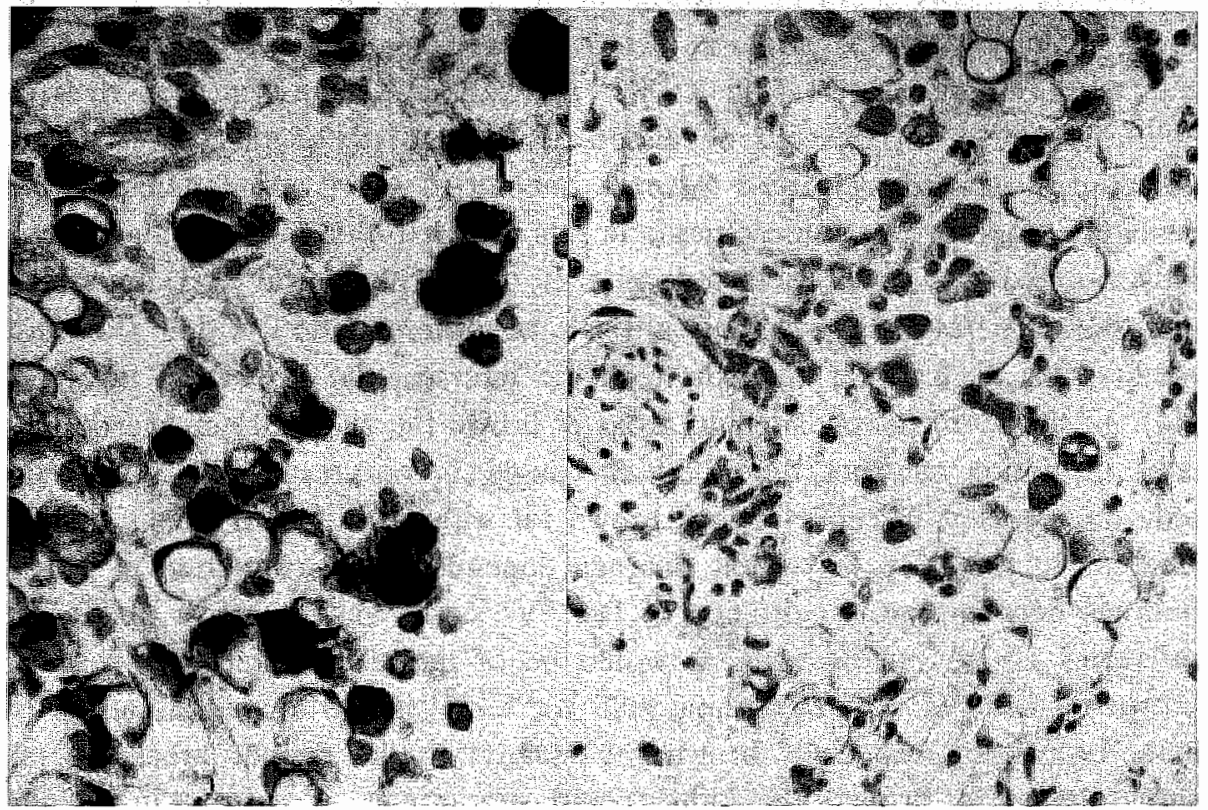


In the periaortic brown fat, virus and viral antigens were present during the first week p.i. in all rats. The route of inoculation of the virus had no effect on the presence of virus or viral antigens in the brown fat along the aorta.

In addition to the in vivo experiments, in vitro infection of brown fat cells was done using the explant technique. For this technique small pieces of interscapular brown fat of 3-week-old rats were maintained in Petridishes containing Minimum Essential Medium (MEM) $+20 \%$ newborn calf serum (Gibco). Infection of these explants was done by adding $10^{5}$ PFU of virus to $5 \mathrm{ml}$ medium. After incubation for 24 hours at $37^{\circ} \mathrm{C}$, the medium was changed and the presence of extracellular virus was assayed over a period of 10 days by inoculating $0.2 \mathrm{ml}$ medium on REF monolayers and performing a plaque assay. By this no virus was detected in the extracellular fluid. In addition, the presence of viral antigens in periaortic and interscapular brown fat was studied by the peroxidase technique as described previously (13). After an incubation period at $37^{\circ} \mathrm{C}$ the organ was fixed, embedded in paraffin, and prepared for immunoperoxidase technique as described previously (13). By this technique many viral antigen(s)-containing brown fat cells were detected. Explants from rats infected s.c. consisted of the interscapular fat obtained 5 days p.i. The explants were maintained as described for the in vitro infection experiments and the supernatants were assayed for the presence of infectious virus for a period of two weeks. As in the in vitro experiments, no infectious virus could be detected in the supernatants, proving that there is no active virus replication in brown fat cells and suggesting that these cells were not permissive for RCMV replication. The presence of virus in interscapular brown fat cells depended on the age of the rats. RCMV was detected in rats younger than 4 weeks but not in older rats. Studies on the development of brown adipose tissue in rats revealled that interscapular brown fat exhibited a very pronounced process of morphological and functional maturation perinatally, reaching a peak of differentiation within the first weeks after birth. After the 4th week the interscapular brown fat involutes (16). In the more deeply situated areas of brown fat, such a clear age dependent involution was not described. Strikingly, in our studies RCMV could only be detected in subcutaneous brown fat within the first 3 weeks of life, whereas in the deep brown fat this age dependency was not found. These findings may imply the presence of RCMV occurs only in active brown fat cells and not in resting cells. It would be of interest to study the role of brown fat cells as virus-containing cells for CMV in the human situation. In man, brown fat, especially brown fat situated in the deeper areas, i.e. as along the aorta, around the kidneys and suprarenals, is present in all age 
groups (17). It is possible that brown fat functions as a target tissue and a reservoir for $\mathrm{CMV}$ infection through human life.

\section{ACKNOWLEDGEMENTS}

The authors wish to thank W.H.M. Debie and V. Heijnen for their excellent technical assistance and Prof.Dr. C.P.A. van Boven for helpful suggestions. This work was supported in part by the Dutch Kidney Foundation (Grant no. C83-399). 


\section{REFERENCES TO CHAPTER VI}

1. M. Ho. Non-human cytomegalowirus. In: Greenough \& Meripan (series editors), Current topics in infectious disease: cytomegalovirus biology and infection, 217-222. Plenum, New York, 1982.

2. F.J. Bua, B.P. Griffith, C.K.Y. Fong, G.D. Hsiung. Cytomegaloviral infections in the guinea pig: experimental models for human disease. Rev. Infect. Dis. 1983; 5: 177-195.

3. J.B. Hudson. The murine cytomegalovirus as a model for the study of viral pathogenesis and persistent infections. Brief review. Archs. Virol. 1979; 62: 1-29.

4. C.A. Bruggeman, H. Meijer, P.H.J.Dormans, W.H.M. Debie, G.E.L.M.Grauls, C.P.A. Van Boven. Isolation of a cytomegallovirus-like agent from wild rats. Archs. Virol. 1982; 73; 231-241.

5. H. Meijer, P.H.J. Dormans, J.L.M.C. Geelen, C.P.A. Van Bowen. Rat cytomegalovirus: studies on the viral genome and the proteins of virions and nucleocapsids. J. Gen. Virol. 1984; 65: $681-695$.

6. H. Meijer, P.H.J. Dormans, C.P.A. Van Boven. Studies on rat cytomegalovirus induced structural and non-structural proteins present at (immediate-)early and late times of infection. Archs. Virol. 1986; 89: 45-56.

7. H. Meijer, J. Dreesen. Molecular cloning and restriction endonuclease mapping of RCMW DNA. J. Gen. Virol. 1986; 67: 1327-1342.

8. C.A. Bruggeman, R. Reinders, W. Debie, P. Frederik, W. Engels, C.P.A. Van Boven. Demonstration of an IgG-Fe receptor in rat cytomegalovirus infected cells. Archs. Virol. 1984; 81: 79-89.

9. C.A. Bruggeman, W.H.M. Debie, G. Grauls, C.P.A. Van Boven. Cytomegalovirus infection of rat endothelial cells in witro. Archs. Virol. 1986; 87: 265-272.

10. C.A. Bruggeman, H. Schellekens, G. Grauls, W.H.M. Debie, C.P.A. Van Boven. Rat cytomegalovirus: Induction of and sensitivity to Interferon. Antiviral Res. 1983; 3: 315-324.

11. H. Meijer, C.A. Bruggeman, P.H.J. Dormans, C.P.A. Van Bowen. Rat cytomegalovirus induces cellular purine and pyridine nucleoside kinases in rat embryo fibroblasts and TK-rat-2 cells. Correlations with the antiviral activity of Acyclovir. FEMS Microbiol. Lett. 1984; 25: 283-287.

12. H. Meijer, C.A. Bruggeman, P.H.J. Dormans, C.P.A. Van Bowen. Rat cytomegalovirus induces cellular purine and pyrimidine nucleoside kinases in rat embryonic fibroblasts and TK- Rat-2 cells. Correlations with the antiviral activity of Acyclowir. Archs. Virol. 1985; 83: 181-194.

13. C.A. Bruggeman, H. Meijer, F. Bosman, C.P.A. Van Boven. The biology of rat cytomegalovirus infection. Intervirol. 1985; 24: 1-9.

14. H. Bruning, C.A. Bruggeman, C.P.A. Van Boven, P.J.C. Van Breda Vriesman. Passive transfer of cytomegalovirus infection by kidney transplantation. Transplant. 1986; 41: 695-698.

15. D.W. Fawcett. A comparison of the histological organization and cytochemical reactions of brown and white adipose tissues. J. Morphol. 1952; 90: 363-405.

16. J.P. Skala. Mechanisms of hormonal regulations in brown adipose tissue of developing rats. Canad. J. Biochem. Cell. Biol. 1984; 62: 637-647.

17. J.M. Heaton. The distribution of brown adipose tissue in the human. J. Anat. 1972; 112: 35-39. 


\title{
CHAPTER VII
}

\author{
PASSIVE TRANSFER OF \\ CYTOMEGALOVIRUS BY CARDIAC \\ AND RENAL ORGAN TRANSPLANTS
}

IN A RAT MODEL

\author{
Johan Hendrik Bruning* \\ Catherina Alberta Bruggeman* \\ Cornelis Pieter Anton van Boven* \\ Peter Jacobus Cornelis van Breda Vriesman**
}

* Department of Medical Microbiology, University of Limburg,

P.O. Box 616, 6200 MD Maastricht, The Netherlands.

Department of Immunology, University of Limburg,

P.O. Box 616, 6200 MD Maastricht, The Netherlands.

Transplantation 1986; 41: 695-698. 
Passive transfer of latent rat cytomegalovirus (RCMV) infection by means of vascularized organ transplants was examined in inbred rat strains. Four to five-week old Lewis rats were infected with RCMV and used as donors at 5 months of age when the infection had become latent. Well-perfused hearts and kidneys were transplanted into unmodified or $5 \mathrm{~Gy}$ x-irradiated syngeneic or allogeneic (Brown Norway) recipients; these rats were sacrificed three weeks after transplantation, and RCMV from various organs was quantitated by means of a plaque assay. Transfer of infection could be accomplished with renal allografts $(60 \%)$ and renal isografts (40\%). When BN hosts were $\mathrm{x}$-irradiated, LEW renal allografts invariably transferred the latent infection (100\%); cardiac allografts rarely did so (8\%). X-irradiation of syngeneic hosts did not enhance the capacity of LEW kidneys to transfer the latent infection. The latent infection could not be transferred with thoracic duct lymphocytes. The results show the transfer of latent infection with well-perfused vascularised organ allografts to be a relative organ-specific phenomenon.

\section{INTRODUCTION}

With the introduction of new effective immunosuppressive agents to control organ rejection, transplantations of a wide variety of tissues and organs can be used for the treatment of various diseases. These immunosuppressants, however, control rejection in a non-specific manner, suppressing general immune-responses rather than reactions to donor-specific antigens. This greatly enhances patient's susceptibility to microbial infections. Among these, herpes virus infections, especially cytomegalovirus (CMV) infections play a dominant role, and have evermore frequently been associated with graft rejection (1, 2). Prospective studies have shown that CMV infecions occur in $50-90 \%$ of renal allograft recipients who are maintained on immuno-suppressive drugs $(3,4,5,6)$. Although primary infections occur in recipients of organ grafts from sero-negative donors, reactivation of latent virus from the recipient, or from the donated allograft, accounts for most infections. In most instances primary infection is derived from the donated kidney allograft $(6,7,8)$, but sometimes blood transfusions administered around the time of transplantation account for the infection. Probably the leucocytes within the blood transfused are responsible for the transmission of CMV infection, as with non leucocyte containing blood derivatives, or with frozen blood, practically no primary infection occurs $(9,10)$. Recently we were able to isolate and characterize a 
CMV of the rat (RCMV) that closely resembles the human cytomegalovirus (HCMV) $(11,12,13)$. This enabled us to investigate in a rat model the possibility that vascularized organ transplants, taken from latently infected donors, are capable of transferring CMV infection. In this study we compared heart and kidney organ grafts in their potential of transferring latent RCMV. The effect of an allogeneic barrier and immunosuppression of the recipient on the infection transfer rate was studied.

\section{MATERIALS AND METHODS}

\section{Animals}

Inbred Brown Norway (BN) and Lewis (Lew) rats were used from our own colonies These rats were bred under specific pathogen-free (SPF) conditions at the Department of Experimental Anumal Services of the University of Limburg, Biomedical Centre, Maastricht, (The Netherlands).

\section{Vinus}

In our studies we used an isolate of a wild rat cytomegalovirus (RCMV) strain recently isolated and characterized by our Department of Medical Microbiology $(11,12,13)$. The virus stock consists of homogenates of salivary glands of four-week old rats, inoculated intraperitoneally (i.p.) with $10^{5}$ plaque-forming units (PFU) of virus. Virus was harvested four weeks after inoculation by homogenizing the saliwary glands in a Ten Broeke grinder in PBS with $25 \%$ sorbitol, and subsequent sonication in a Branson B12 cell disrupter for $30 \mathrm{sec}$. Upon clarification by centrifugation ( 5 min $400 \mathrm{xg}$ ), the supernatant was stored in small aliquots at $-70^{\circ} \mathrm{C}$ until use, after quantification with the plaque-assay (vide infra).

\section{Infection}

Experimental (acute) infections were established by inoculating four to five-week old rats i.p. with $10^{4}-10^{5} \mathrm{PFU}$ of RCMV. In previous work we defined rats to be chronically infected when only the salivary glands appeared to be RCMV-positive upon culture, with all the other organs being RCMV-negative. If all the organs of infected rats were found to be RCMV-negative upon culture, including the saliwary glands, we defined them as latently infected. As 5 months after infection all organs of infected animals appeared to be RCMV-negative upon culture, except the salivary glands in some instances $(11,12)_{n}$ in this study we differentiated between latently and chronically infected animals merely by the absence or presence of RCMV in the salivary glands. For that purpose pue took a surgical biopsy of the salivary glands and cultured their homogenates as described (wide infra).

\section{Vinis asays}

Quantitative assays for infections virus were performed by plaque assays, a modification of the method described by Wentworth et al. (14), and previously described (11). In short, organ biopsies were homogenised in a Ten Broeke grinder in Minimal Essential Medium (MEM) (Gibco) supplemented with $10 \%$ newborn calf serum. This suspension (10\% weight/volume) was further diluted ten times (volume/volume) and cultured on a monolayer of ratembryonic fibroblasts (REF) in a $\mathrm{CO}_{2}$ incubator under a final concentration of $0,25 \%$ agarose. The plaques were counted by microscopic observation 7 days post infection, after staining with methylene blue, and are expressed in ${ }^{10} \mathrm{Log}$ PFU/ml. (v/v) diluted organ suspension. 


\section{Inumunosuppression}

Immunosuppression of the rats that received an organ transplant was achieved by $\mathrm{X}$-irradiation with 5 Oy. X-Rays were generated by a Philips-Muller MG 320 apparatus and additional filtered through $1,0 \mathrm{~mm} \mathrm{Cu}$. filter. The thickness of this filter was adapted to correct for field homogeneity. Rats to be irradiated were placed on a layer of $11 \mathrm{~cm}$ harboard to obtain maximal backscatter. X-Ray dose was measured during irradiation using a $0,6 \mathrm{cc}$ ionization chamber $\mathrm{r}_{0}$ connected to adigital dose/ rate meter (Ionex 2500-3, Nuclear Enterprises, Beenham, England). Up to three rats were placed in a well aerated round perspex box and irradiated at a source to subject distance of $42,5 \mathrm{~cm}$. X-Rays were generated at $250 \mathrm{kV}, 10 \mathrm{~mA}$

\section{Transplantations}

Orthotopic renal and cardiac transplantation were performed according as described previously (15). In order to avoid an effect of uraemia (16) on the reactivation of transferred latent virus, hearts and kidneys were transplanted into unilaterally nephrectomised recipients. Lew renal allografts inserted into unmodified $\mathrm{BN}$ recipients were removed 8 days postoperatively when they were invariably irreversable rejected. LEW kidneys transplanted into 5 Gy $x$-irradiated $B N$ hosts were not rejected histologically three weeks postoperatively, when the hosts were stacrificed. The function of heart transplants was assessed by means of palpation; when grafts contracted vigorously (3+.on a scale of 1 to 3), they were accepted as successful (17). Kidney transplants were considered successful when normal renal tissue was found at the time of sacrifice of isogeneic LEW, or $\mathrm{x}$-irradiated BN hosts, or when classic haemorrhagic rejection was seen at 8 days post operation in LEW kidneys residing in unmodified BN hosts. In addition, the function of LEW kidneys residing in $x$-irradiated BN and LEW hosts was tested at 14 days post operation by means of ${ }^{13 i}$ hippuran nuclear imaging (18). In all instances a clearcut uptake of hippuran was seen in the transplants; no attempts were made to quantitate the effective renal plasma flow.

\section{Periptheral blood $T$ cells and thoracic duct cells}

Thoracic duct cells were harvested as described by van Schilfgaarde et al. (17). Peripheral blood $T$ cells were obtained from heparinised blood. The buffy coat was further purified by lysing the erythrocytes with an ammonium chloride shock. The $T$ cells were isolated from it as described by Julius et al. (19) on a nylon wool column. These cells were $96 \% \mathrm{~T}$ cells, as was shown by positive staining with the monoclonal antibody W3/13 (Sero-Tek).

\section{RESULTS}

\section{Natural history}

With plaque assays we were able to demonstrate virus in most organs only during the first week of an infection, as is shown in Table I (only kidney and heart in these experiments). After this first week no virus was detectable in any of the organs mentioned. The salivary glands, the organs in which the highest virus concentrations are reached, do not become RCMV-positive upon culture before the end ofthe second week. In immunosuppressed animals, upon experimental infection, higher virus concentrations were measured in most organs. In the kidneys, for example, $2,5 \times{ }^{10} \mathrm{Log} \mathrm{PFU} / \mathrm{ml}$ was measured in the immuno-suppressed rats, versus $1,2 \times{ }^{10} \mathrm{Log} \mathrm{PFU} / \mathrm{ml}$ in the untreated rats; and in the salivary glands $4,8 \times{ }^{10} \mathrm{Log} \mathrm{PFU} / \mathrm{ml}$ versus $3,5 \mathrm{x}{ }^{10} \mathrm{Log} \mathrm{PFU} / \mathrm{ml}$ in the 
untreated rats, two weeks after infection. The spleen remained virus positive upon culture up to more than four weeks in the immunosuppressed animals versus only a few days in the untreated rats (Table I).

\section{Transplantation}

We used the salivary glands to detect the passive transfer of RCMV with organ grafts in our transplantation experiments, as in experimental infection with RCMV the highest concentration of virus was found in the salivary glands, three to four weeks after inoculation. The homogenized suspension of a surgical biopsy of the recipients salivary glands were used for plaque assay on REF, as described. It appeared that latent RCMV infection can readily be transferred by well perfused renal transplants inserted into syngeneic and allogeneic recipients. When renal allografts were used, amplification of RCMV was observed in comparison to renal isografts yielding a transfer rate of $67 \%$ versus $43 \%$ in the syngeneic model (Table II). Apart from an allogeneic barrier, immuno-suppression of the recipient appeared to enhance the reactivation of latent virus in renal grafts, but only in the allogeneic model $100 \%$ in the immuno-suppressed allogeneic recipients versus $67 \%$ in the untreated allogeneic recipients). In the syngeneic model transfer of RCMV infection with the renal grafts occurred even less frequent in the immuno-suppressed recipients than in untreated rats $(29 \%$ in the immuno-suppressed, versus $43 \%$ in the untreated recipients)(Table II). Well perfused heart allografts were far less effective than renal allografts in the transfer of RCMV infection. Only in $25 \%$ of the untreated recipient rats we succeeded in establishing an infection. When the recipient rats were immunosuppressed by total body irradiation, this infection rate further decreased to only $8 \%$. Another marked difference between cardiac and renal transplantations was the observed virus titers in the recipient organs 3 weeks after transplantation (data not shown). In the immuno-suppressed recipients, in which the highest titers were measured when transfer of infection had succeeded, $10^{4}-10^{6}{ }^{10} \mathrm{Log} \mathrm{PFU} / \mathrm{ml}$ was measured in the salivary glands of recipients of renal allografts versus $2,5-10^{3} \mathrm{PFU} / \mathrm{ml}$ in the recipients of cardiac allografts. Surprisingly, the spleen of the recipients of cardiac allografts remained virus negative, even if they were immuno-suppressed, whereas the spleens of the recipients of renal allografts reached virus titers of $10^{2} \mathrm{PFU} / \mathrm{ml}$, when the recipients were immuno-suppressed. In the untreated recipients no virus was measured in the spleens upon culture, nor in the spleens of recipients of renal isografts whether or not immunosuppressed. When kidneys or hearts were transplanted into unmodified allogeneic recipients, the organ grafts were removed one week after transplantation. 


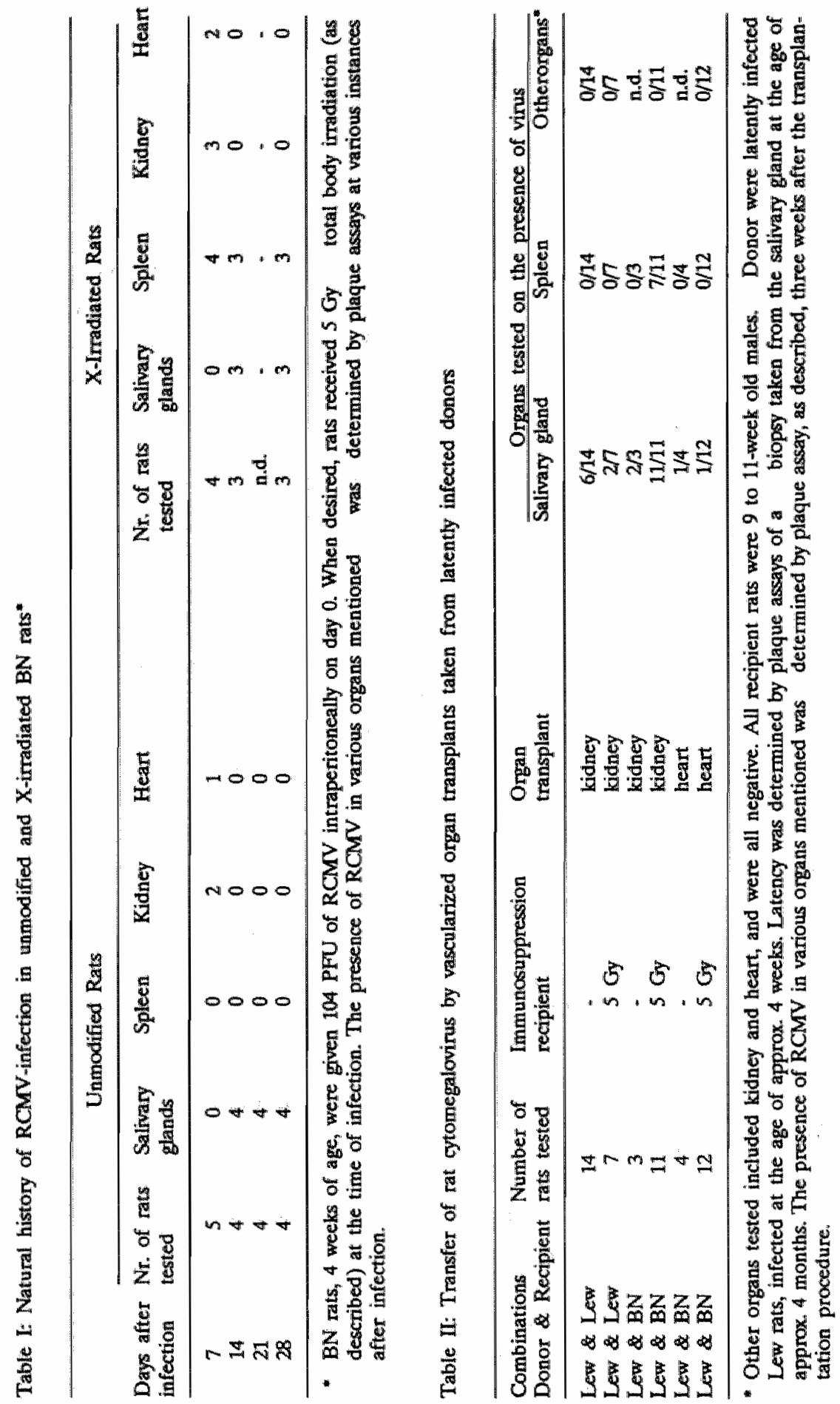




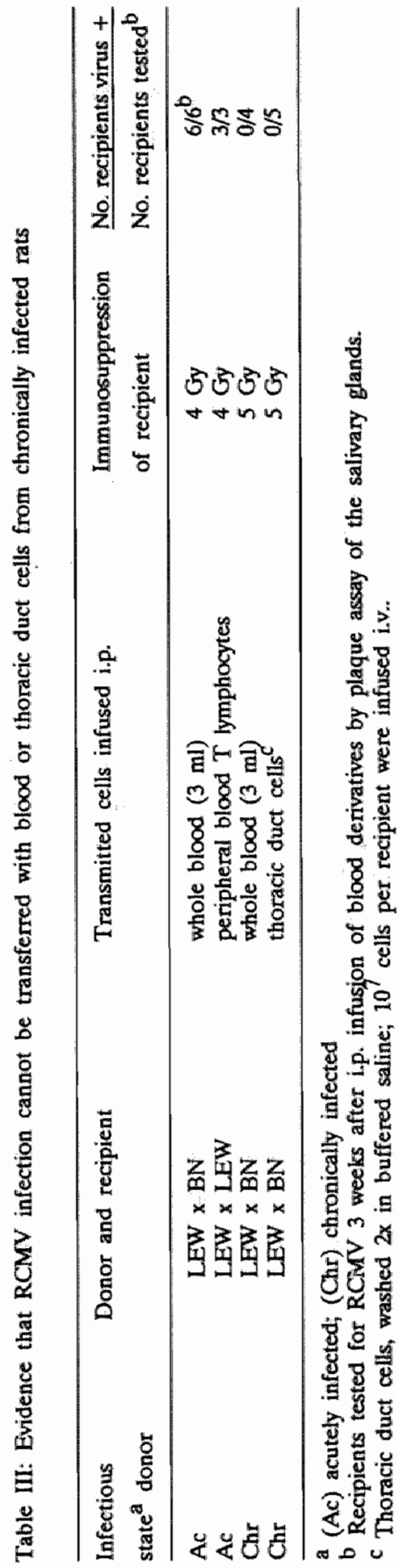




\section{DISCUSSION}

There were two main findings in this study. Firstly, in the passive transfer of RCMV infection, kidney transplants are a more effective than heart transplants. This is particularly evident when allografts are inserted into immunosuppressed hosts.

Secondly, passive transfer of latent infection cannot be accomplished by means of transfusion of peripheral blood cells or thoracic duct cells into syngeneic or allogeneic hosts.

In theory passenger leucocytes are attractive candidates for passive transfer of CMV since clinical evidence supports a role for leucocytes in the transfer of human cytomegalovirus (HCMV) infections.

Some authors have shown that blood transfusions of sero-positive donors administered around the time of transplantation were frequently associated with active $\mathrm{CMV}$ infection, but when leucocyte deprived blood derivatives of frozen blood were used practically no primary infection occurred $(9,10)$.

Human lymphocytes and monocytes can be infected with $\operatorname{HCMV}(20,21)$. Thus passenger leucocytes residing in the kidney and heart transplants are potential candidates for the transfer of RCMV infections.

These passenger leucocytes include bone-marrow-derived interstitially located dentricic cells (22, 23), T-lymphocytes (24) and probably monocytes (25) and B-lymphocytes (26). Compared with the heart, however, the rat kidney contains at least four times the number of recirculating lymphocytes $(17,24)$, part of which are mobile and capable of migrating out of the renal allograft into the spleen of the recipient (24).

Since we did not succeed in transferring latent RCMV infection with $10^{7}$ thoracic duct cells (Table III), which include all of the passenger leucocytes mentioned except significant numbers of dendritic like cells, it is unlikely that the passive transfer of latent RCMV infection with allogeneic renal transplants is caused by any of these passenger leucocytes. The number of the thoracic duct cells used is far above the number of leucocytes that is thought to reside in one kidney $(17,24)$ and in the order to $2 \times 10^{6}$ cells. Although these experiments do not exclude passive transfer of RCMV via interstitial dendritic cells, these cells are unlikely candidates because both heart and kidney possess large numbers of these cells on the basis of immunohistochemical staining $(22,23)$. Thus, the observed "organ specificity" of transfer of infection with vascularized allograft cannot be easily explained in this way.

Alternatively, the latent virus is present in organ specific organelles, e.g. the renal tubular epithelial cells or (glomerular) vascular endothelium. This is 
supported by the findings in human kidneys where virus has been isolated from allografted kidneys sampled by needle biopsy and at autopsy $(1,4,5,28,29)$. More pertinent is the observation that in glomerular endothelial cells and renal tubular cells of allografts characteristic inclusion bodies have been observed histologically $(29,30)$ and the viral genome has been demonstrated by DNA in situ hibridisation $(31,32)$.

Preliminary data from our rat model support these findings (data not published). In this view latent RCMV infections (are transferred more effectively with renal than with cardiac allografts because the kidney contains a greater number of infected cells.

\section{ACKNOWLEDGEMENTS}

We thank Ilse Heuts, Wiel Debie and Gert Grauls for their valuable assistance with these studies.

This work was supported by the Netherlands Kidney Foundation (NSN). 


\section{REFERENCES}

1. M. Fiala, J.E. Payne, T.V. Bern, T.C. Moore, W. Henle, J.Z Montgomerie, S.N. Chaterjee, L.B. Guze. Epidemiology ofcytomegalowinus infection after transplantation andimmunosuppression. J. Inf. Dis. $1975 ; 132: 421-433$.

2. C. Lopez, R.L. Simmons, S.M. Mauer, J.S. Najarian, R.A. Good, S. Centry. Association of renal allograft rejection withvirus infections. Am. J. Med. 1974; 56: 280-289.

3. J.R Armstrong, A.S. Evans, N. Rao, M. Ho. Viralinfections in renal transplant recipients. Infect. Immun. 14: 970-975.

4. J.E Craighead, J.B, Hanshaw, C.B. Carpenter. Cytomegalowirus infection after renal allo transplantation.J.A.M.A. 1967; 201: 725-728.

5. RL. Simmons, $\mathrm{H}$. Lopez, Balfour $\mathrm{J}_{\mathrm{r}}$, et al: Cytomegalovirus: clinical virological correlations in renaltransplant recipients. Ann. Surg. 1974; 180: 623-624.

6. M. Ho, S. Suwansirikul, J.N. Dowling, L.A. Youngblood, J.A. Armstrong. The transplanted kidney as source of cytomegalowinus infection. New Engl. J. Med. 1975; 292: 1109-1112.

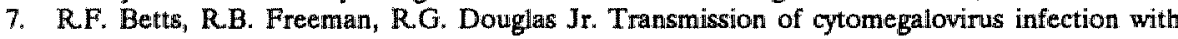
renal allograft.Kidney int. $1975 ; \mathrm{E}: 385-392$.

8. R.F. Pass, W.K. Long, R.J. Whitley, S.J. Soong, A.G. Diethelm, D.W. Reymolds, C.A. Alford Jr. Productive infectionwith cytomegalowirus and herpes simplex virus in renal transplant recipients: Role of source of kidney.J. Infect. Dis. 1978; 137: 556-563.

9. R.F. Betts, R.B. Freeman, RG. Douglas $J_{r}$, T.E. Talley. Clinical manifestations of renal allograft derived primary cytomegalowirus infection. Am. J. Dis. Child.1977; 131: 759-763.

10. F. Thomas, H.M. Lee, J.S. Wolf, G. Mendez-Picon, J. Thomas. Monitoring and modulation of immune reactivity inhuman transplant recipients. Surgery 1976; 79: 408-413.

11. C.A. Bruggeman, H. Meijer, P.H.J.Dormans, W.M.H. Debie, G.E.L.M. Grauls, C.P.A. van Boven. Isolation of a cytomegalovirus-like agent from wild rats. Arch. Virol. 1982; 73: 231-241.

12. C.A. Bruggeman, W.H.M. Debie, G.E.L.M. Grauls, F. Majoor, C.P.A. van Boven. Arch. of Virol. 1982; 76: 189-199.

13. H. Meijer, P.H.J. Dormans, J.L.M.L. Geelen, C.P.A. van Boven. Rat cytomegalovirus: Studies on the viral genome and the proteins of virus and nucleocapsids. J. Gien.Virol. 1984; 65: 681-695.

14. B. Wentworth, L. French. Plaque assay of CMV strains of human arigin. Proc. Soc. Exp. Biol. Med. 1970; 135: 253-258.

15. P.J.C. van Breda Vriesman, L. Swanen-Sierag, L.F.M. Vlek. Cytotoxic and enhancing properties of early gamma-M alloanttibodies elicited by first set renal allografts. Transplantation 1975; 20: 385 .

16. R.L. Souhami, J. Smith, J.W.B. Bradfield. The effect of uraemia on organ graft survival in the rat. Br.J. Exp. Path. 1973; 54: 183.

17. R. van Schilfgaarde, P. Hermans P, J.L. Terpstra, P.J.C. van Breda Vriesman. Role of mobile passenger lymphocytes in the rejection of renal and cardiac allografts in the rat. Transplantation 1980; 29: 209-213.

18. T.A. Egleston, et al. 1311-Hippuran in the evaluation of transplanted kidneys. Radiology 1969; 93: 1145 .

19. M.H. Julius, E. Simpson, L.A. Herzberg. A rapid method for the isolation of functional thymusderived murine lymphocytes. Eur. J. Immunol. 1973; 3: 645.

20. G.P.A. Rice, R.D. Schrier, M.B.A. Oldstone. Cytomegalovirus infects human lymphocytes and monocytes: Virus expression is restricted to immediate-early gene products. Proc. Nath. Acad.Sci. USA. 1984; 81: 6134-6138.

21. H.M. Garnett, et al. Isolation of human cytomegalovirus from peripheral blood T-cells of renal transplant patients. J. Lab. Clin. Med. 1982; 99: 92-97.

22. D.N.J. Hart, J.W. Fabres. Demonstration and characterization of Ia-positive dendritic cells in the interstitial connective tissues of rat heart and other tissues, but not in brain. J. Exp. Med. $1881 ; 154: 347-361$.

23. D.N.J. Hart, J.W. Fabre. Major histocompatibility complex antigens in rat kidney, ureter and bladder. Transplantation 1981; 31: 318-325.

24. R. vzn Schilfgaarde, P. Hermans, J.L. Terpstra, P.J.C. van Breda Vriesman. Influence of recirculating lympocytes in the rejection of renal and cardial allografts in the rat. Transpl. Proc. 1979; 11: 1485-1488. 1979; 11: 1485 . 
25. G.G. MacPherson, M.J. Murphy, B. Morris. The traffic of mononuclear phagocytes through renal allografts in sheep. Transplantation $1977 ; 24: 16-18$.

26. M.R. MacDermott, J. Bienenstock. Evidence of a common mucosal immunological system. J. Immunol. 1979: 122: 1892-1898.

27. E.S. Spencer. Clinical aspects of CMV infection in kidney graft recipients. Scand J Infect. Dis. 1974; 6: 315-323.

28. S. Naraqi, G.G. Jackson, O.M. Jonasson et al. Prevalence, incidence and source of infections with herpesviruses in patients with renal allografts. J. Infect. Dis.1977; 136:531-540.

29. D. Rifkind, N. Goodman, R.G. Hill $\mathbf{J}_{r}$. The clinical significance of CMV infection in renal transplant recipients.Ann. Intern. Med. 1967; 66: 1116-1128.

30. G.H. Fetterman, F.E. Sherman, N.S. Fabrizio, F.M. Studnickie. Generalized cytomegalic inclusion disease. Arch. Pathol.1968; 86: 86-94.

31. J.S. Pagano. Diseases and mechanisms ofpersistent DNA virus infections: latency and cellular transformationJ. Infect. Dis. 1975; 32: 209-233.

32. D. Myerson, Hackman, J.A. Nelson, D.C. Wand, J.K. McDougall. Widespread presence of histologically occult cytomegalovirus. Human Pathology 1984; 15: 430-439. 
THE ROLE OF TRANSFUSIONS OF BLOOD, BLOODDERIVATIVES AND RENAL CELLS IN THE

\title{
TRANSFER OF CYTOMEGALOVIRUS INFECTIONS
}

\author{
Johan Hendrik Bruning* \\ Catherina Alberta Bruggeman* \\ Peter Jacobus Cornelis van Breda Vriesman**
}

* Department of Medical Microbiology, University of Limburg,

P.O. Box 616, 6200 MD Maastricht, The Netherlands.

** Department of Immunology, University of Limburg,

P.O. Box 616, 6200 MD Maastricht, The Netherlands.

Submitted for publication 
SUMMARY

In this study the role of leucocytes and renal cells in the transfer of cytomegalovirus infections were tested in a rat model. Previously we demonstrated that renal allografts were far more effective in the transfer of rat cytomegalovirus (RCMV) infections when compared to cardiac allografts. It was speculated that this is explained by the difference in the number of passenger leucocytes present within these grafts. Therefore the transfer of RCMV infection by leucocytes obtained from peripheral blood (PBL), thoracic duct (TD), spleen (S.C.) or peritoneal cavity (PEC) was tested and compared to the infectivity of renal cells obtained from the same donor rats. The results indicate that, irrespective of their origin, these cells were capable of transferring RCMV infections, but only when obtained from acutely infected rats, i.e. within 10 days post infection.

In contrast, when these cells were obtained from chronically or latently infected donors, they could not transfer infection.

Further it appeared that latent RCMV infections only could be transferred with complete viable organ grafts.

\section{INTRODUCTION}

Similar to the situation in man $(1,2)$, rat-CMV (RCMV) infections can readily be transferred with complete viable organ grafts $(3,4)$.

Infection is transferred considerably more frequently by renal grafts than by cardiac grafts, a phenomenon that might be explained by the difference in the number of passenger leucocytes present within the grafts (3-6). Compared to the heart the rat kidney contains at least four times the number of recirculating leucocytes $(5,6)$, part of which are mobile and capable of migrating out of the renal allograft into the spleen of the recipient (6). Most of these recirculating leucocytes follow the route of the thoracic duct towards the spleen and vice versa, to the heart or kidney, although recirculation via the blood or via the peritoneal cavity and lymphatic duct may also occur.

Immunohistochemical and virological studies have shown that the spleen contains relatively high titres of infective virus during an acute RCMV infection $(7,8)$. For that reason the capability to transfer RCMV infections by thoracic duct leucocytes (TDL), peripheral blood leucocytes (PBL), spleen cells (SC), peritoneal exudate cells (PEC) or whole blood was studied. Single cell suspensions of the indicated sources were infused intraveneously (i.v.) or intraperitoneally (i.p.) into allogeneic or syngeneic rats. Since CMV infection 
readily is transferred with complete viable renal grafts (3); cellular subfractions of these kidneys were tested as well on their ability to transfer infection. Transfer of infection was assessed by plaque assay of the recipients' salivary glands three weeks after the infusion of cells.

\section{MATERIALS ANDS METHODS}

\section{Animals}

Inbred male Brown Norway (BN) and Lewis (Lew) rats were used. These rats were bred under specific-pathogen-free (SPF) conditions at the Department of Experimental Animal Services of the University of Limburg, Biomedical Centre, Maastricht, The Netherlands.

\section{Virus and viral antigens}

The isolate of a wild rat Cytomegalowirus (RCMV) strain as described before $(7,8)$ was used throughout the study. The virus stock consisted of homogenates of salivary glands, and was prepared by inoculation of four-week-old rats i.p. writh $10^{5}$ plaque-forming units (PFU) of virus. From the rats the saliwary glands were harvested 3-4 weeks after inoculation.

For the detection of viral antigens a panell of anti-RCMV mouse monoclonal antibodies (9) and rat hyperimmune serum was used in an indirect immunoperoxidase assay on paraffin embedded tissue sections.

\section{Infection}

Experimental (acute) infections were established by inoculating 4-5 weeks old rats i.p. with $10^{4}$ $10^{s} \mathrm{PFU}$ of RCMV. In this study we discriminated between latently and chronically infected animals merely by the absence or presence of RCMV in the salivary glands six weeks after infection, as determined by plaque-assay of the homogenates of a surgical biopsy.

Since the main criterion of latency is the absence of infective virus, and at six weeks after infection all organs (including the kidney) were virusnegative upon culture, we designated these organs as latently infected.

The (llatent) virus is present in $100 \%$ of the kidneys as has previously been demonstrated by transfer studies (3).

\section{Virus assays}

Quantitative assays for infectious virus were performed by plaque assay as described before $(7,8)$

\section{Immunosuppression}

Total body $\mathrm{X}$-irradiation (TBI) was administered at the indicated dose just prior to transplantation as previously described (3).

\section{Spleen cells}

Single cell suspensions of spleens were obtained as follows: The surrounding fat and the capsulum were carefully removed, the organs were cut into small pieces with stainiess steel scissors, and under continuous dropwise addition of cold RPMI-medium carefully pressed through a nylon gauze sieve (Monodur PA 100, Stokvis, Haarlem, The Netherlands) with a metal spatula. 
The fymphoid cell surpension was then collected, washed once in cold RPMI (100 $250 \times 8_{0}^{\circ} 4^{\circ} \mathrm{C}$ ) and viability was determined by trypan blue exclusion. Viability usually was about $20 \%$. The splenocytes, obtained from infected donor rats, were tested on their ability to transfer RCMV infection by $i . w_{0}$ or i.p. infusion of $10^{6}$ viable cells into allogeneic rats, immuno-suppressed by $400-500$ Rads of total body irradiation (TBI).

\section{Peripheral blood leucacyes (PBL), Thoracic duct cells (TDL) and T-cells}

Thoracic duct cells were harvested as described by van Schilfgaarde et al. (5). Peripheral bllood cells were obtained from heparinised blood obtained by artic puncture. The buffy coat was further purified by lysing the erythrocytes with an anmonium chloride shock. The T-cells were isolated from it as described by Julius et al. (10) on a nyion wool column. These cells were $98 \%$ T-cells, as was shown by positive staining with the monoclonal antibody (W3/13 (Pan T, Sero-Tek). These cells obtained from infected donons were tested on their infectivity by i.p. or i.v. infusion into allogeneic immunosuppressed rats (400 or $500 \mathrm{Rad}$ ) at the indicated dose.

\section{Peritoneal exudate cells (PEC)}

Peritoneal cells were collected by intraperitoneal injection of $20 \mathrm{ml} \mathrm{Hamks'} \mathrm{Balanced} \mathrm{Salt} \mathrm{Solution}$ (HBS5) supplemented writh $10 \mathrm{mMEDTA}$ and $20 \mathrm{mM}$ Hepes (pH7.4). Subsequently, macrophages were purified by centrifugation on a metrizamide gradient (Nycomed, Oslo, Norway). A $12.75 \%(\mathrm{w} / \mathrm{v}$ ) solution of metrizamide in Krebs-Ringer-Tris buffer ( $\mathrm{pH}$ 7.4) was prepared according to the manufacturer's manual. On $2.0 \mathrm{ml}$ of this solution, $0.5 \mathrm{ml}$ of a suspension containing $10^{7}$ peritoneal cells. was layered and after centrifugation for $30 \mathrm{~min}$. at $5000 \mathrm{xg}$ at $4^{\circ} \mathrm{C}$, the interphase $(90-95 \%$ macro. phages) was collected and washed three times with HBSS. Macrophages were then counted and the viability determined by trypan blue exclusion. This was always greater than $98 \%$.

The ability to transfer RCMV infection when obtained from infected donor rats was tested by i.p. infusion into irradiated or unmodified syngeneic rats at a dose of $2,5 \times 10^{6}$ cells/recipient as described for the other cells.

\section{Proteose Peptone treatment}

RCMV infected rats that served as donors for PEC in infection-transfer studies, were in some cases treated with proteose peptone (Difco Laboratories, Detroit, Mich) as indicated (Table II). This was done to elicit a non-specific inflammatory reaction in the peritoneal cavity resulting in activation and influx of PEC into the peritoneum.

At various times post infection (as indicated in Table II), RCMV infected rats obtained $5 \mathrm{ml}$ of $2 \%$ sterile proteose peptone intraperitoneally. Four days later the peritoneal cavity was opened by a midline incision and PEC were harvested as described.

\section{Preparation of wiable renal subfractions}

Ether anaesthesised rats were bled via the vena cava inferior, and the kidneys freed from blood by perfusion with isotonic saline via the left cardiac ventricle.

Then the kidneys were removed and cut into slites of $0,5 \mathrm{~cm}$ in thickness after carefully stripping the capsules.

Next the kidneys were further disaggregated using either an enzymatic digestion technique, or a mechanical technique with the aid of fine mesh stainless steel screens.

- Enzymatic method. The renal slites were dissected into $1-2 \mathrm{~mm}^{3}$ pieces with a scalpel on glass; these pieces were incubated in $20 \mathrm{ml}$. of Minimal Essential Medium (MEM; Gibco) supplemented with $0.1 \mathrm{mg} / \mathrm{ml}$ Papain, $0.1 \mathrm{mg} / \mathrm{ml}$ DNA se and $0.25 \mathrm{mg} / \mathrm{ml}$ Pronase (Sigma) at $37^{\circ} \mathrm{C}$ for $105 \mathrm{~min}$. under continuous stirring with a magnetic stirrer.

Every 15 min. the fragments were allowed to settle by gravity; the supernatant was discardied and the fragments were resuspended in fresh digestive enzymes containing warm medium. After $105 \mathrm{~min}$. the suspension was rapidly centrifuged at $9^{\circ} \mathrm{C}$ for $5 \mathrm{~min}$. at $350 \mathrm{xg}$ and the sediment 
was resuspended in MEM supplemented with $10 \%$ w/N Newborn Calf Serum (NCS; Gibco), packed again by centrifugation for 5 min. at $4^{\circ} \mathrm{C}, 350 \mathrm{xg}$, followed by gently pressing the pellet through a fine mesh nylon gauze sieve with a metal spatula, under continuous dropwise addition of cold MEM supplemented with $10 \%$ NCS.

The renal fractions isolated in this fashion contained a mixture of glomeruli and tubular fragments (1:1) and single mononuclear cells. Viability was assessed with trypan blue and usually exceeded $80 \%$.

- Mechanical disaggregation method (A). The kidneys were disaggregated with the aid of a series of stainless steel screens (100-140-170 mesh).

The renal slites of $0,5 \mathrm{~cm}$ in thickness were first dissected into $1-2 \mathrm{~mm}^{3}$ pieces with a scalpell on a glass plate. Next these pieces were gently rubbed on a 100 mesh stainless steel screen under continuous dropwise addition of cold MEM, supplemented with $10 \%$ NCS, until the fragments were pressed through. The remains on this screen and clinging to it on the other site wel washed off with the aid of a pasteurs pipette and collected in MEM with NCS. This fraction consisted mainly of fibrous material and vascular fragments.

The rest was gently rubbed through a 140 mesh sereen, followed by passage through a 170 mesh screen.

The fraction that passed through this last screen contained predominantly intact glomeruli. Contamination of mononuclear cells and tubular fragments was less than $5 \%$. Viability by trypan blue exclusion was approximatelly 60-75\%.

(Method B) Alternatively crude cell suspensions were made of renal cortex and medulla: Cortex and medulla were separated macroscopically followed by dissection into $2-3 \mathrm{~mm}^{3}$ pieces; these were gently rubbed through a 100 mesh stainless steel screen.

Crude suspensions of whole decapsulated kidneys were prepared by dissection with a Dounce homogeniser (Method C).

From each fraction of both the enzymatically and mechanically dissected kidneys, the equivalent of one whole kidney obtained from an infected donor rat was injected intraperitoneally into irradiated rats to assess their ability to transfer CMV infections. Transfer of infection was tested by plaque assay of homogenates of the recipients salivary glands, three weeks after infusion of the renal fractions.

\section{RESULTS}

Transfer of infection by blood, bloodderivatives, TD-cells or PEC

Blood (2-5ml), bloodderivatives (1065 $-10^{7}$ buffy coat cells, $10^{7} \mathrm{~T}$-cells, or $3 \mathrm{ml}$ serum), PEC $\left(2,5 \times 10^{6}\right)$ or TD $\left(10^{6}-10^{8}\right)$ were injected i.p. or i.v. into allogeneic or isogeneic immunosuppressed rats. Three weeks after infusion of cells, a surgical biopsy of the recipient's salivary glands was tested in a plaque assay to assess transfer of infection. The results are shown in Table I and II.

Transfer of RCMV infection is readily accomplished with whole blood, buffy coat cells of this blood, purified T-cells, TDL and PEC, but only when these blood products were obtained from acutely infected donor rats, i.e. within 10 days post infection of the donor rats.

The transfer rate was almost $100 \%$ in all instances. The transfer of RCMV appeared to be cell-associated since transmission of infection could not be accomplished with serum of the same donor rats. When the cell suspensions 
mentioned were obtained from chronically infected donors, no transfer of infection occurred (Table I).

Transfer of RCMV infection via viable cell suspensions of kidneys

In these experiments cell suspensions prepared as described were injected i.p. into irradiated allogeneic recipient rats. It appeared that infection could only be transferred when the kidney cell suspensions were obtained from acutely infected (on day 4 to 7 post infection) donor rats. The results are shown in Table III.

This parallells exactly the period in which transfer of infection could be accomplished in the same manner with whole blood (Table I).

After this period infection could not be transferred neither with kidney cell suspensions nor with blood cell suspensions.

From kidneys of latently infected rats we prepared viable fractions from the cortex and medulla as described. Furthermore, subfractions containing predominant glomeruli, tubuli or renal vasculature fragments of these kidneys were tested on their potential in transferring RCMV infections. As is shown in table III none of the fractions mentioned were able to transfer a RCMV infection.

\section{DISCUSSION}

As was shown previously $(3,5)$, RCMV infection can readily be transferred by organs grafts. The finding that renal allografts were far more effective than cardiac allografts might be explained in differences in the amounts of passenger leucocytes present in these organ grafts.

In this study it was shown that RCMV infection could readily be transmitted with whole blood, TD-cells, PBL (buffycoat) or PEC obtained from acutely infected donor rats (Table I) emphasizing this assumption. The role of bloodborne cells in the transmission of RCMV infection is further supported by the fact that with viable kidney cell suspensions infection could be transmitted in exactly the same period in which transfer of infection could be accomplished in the same manner with whole blood (i.e. day 4-7 p.i.; Table I). 


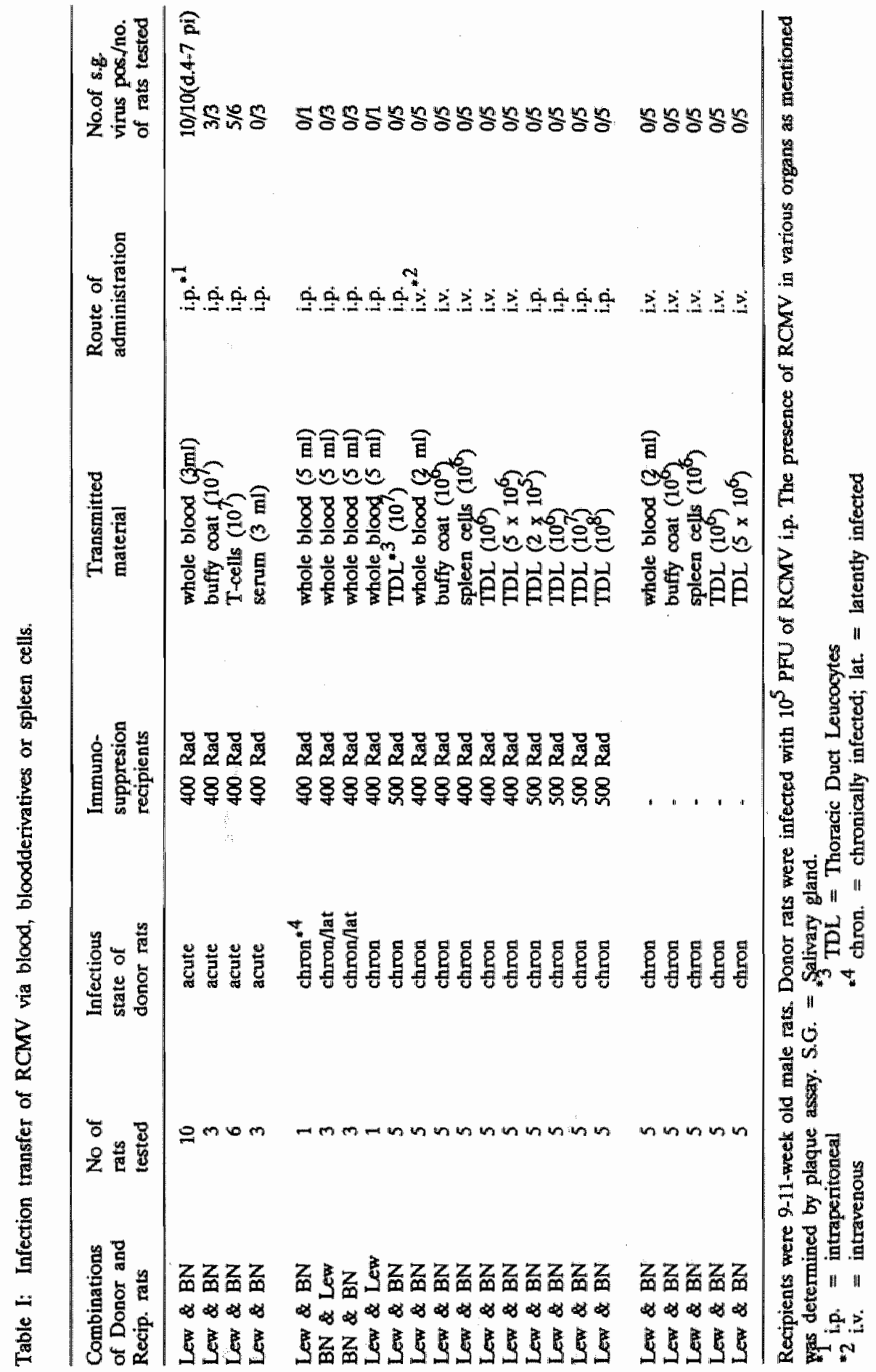




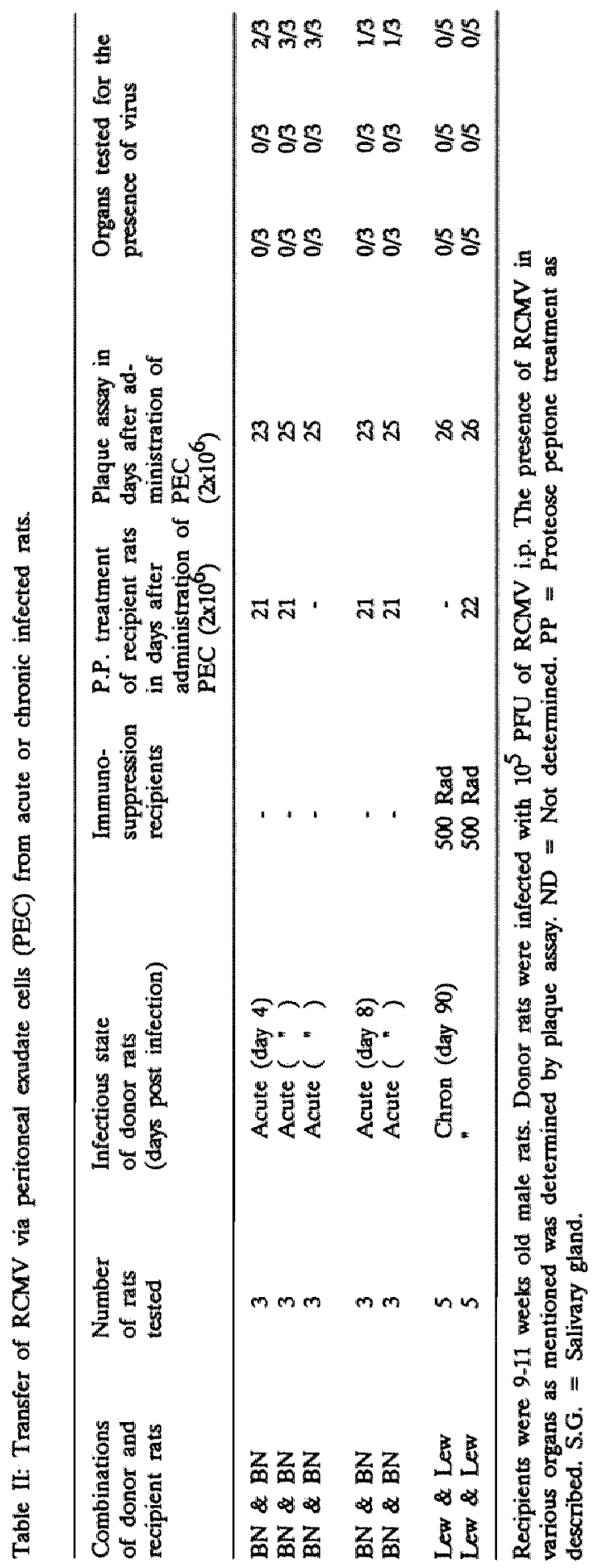




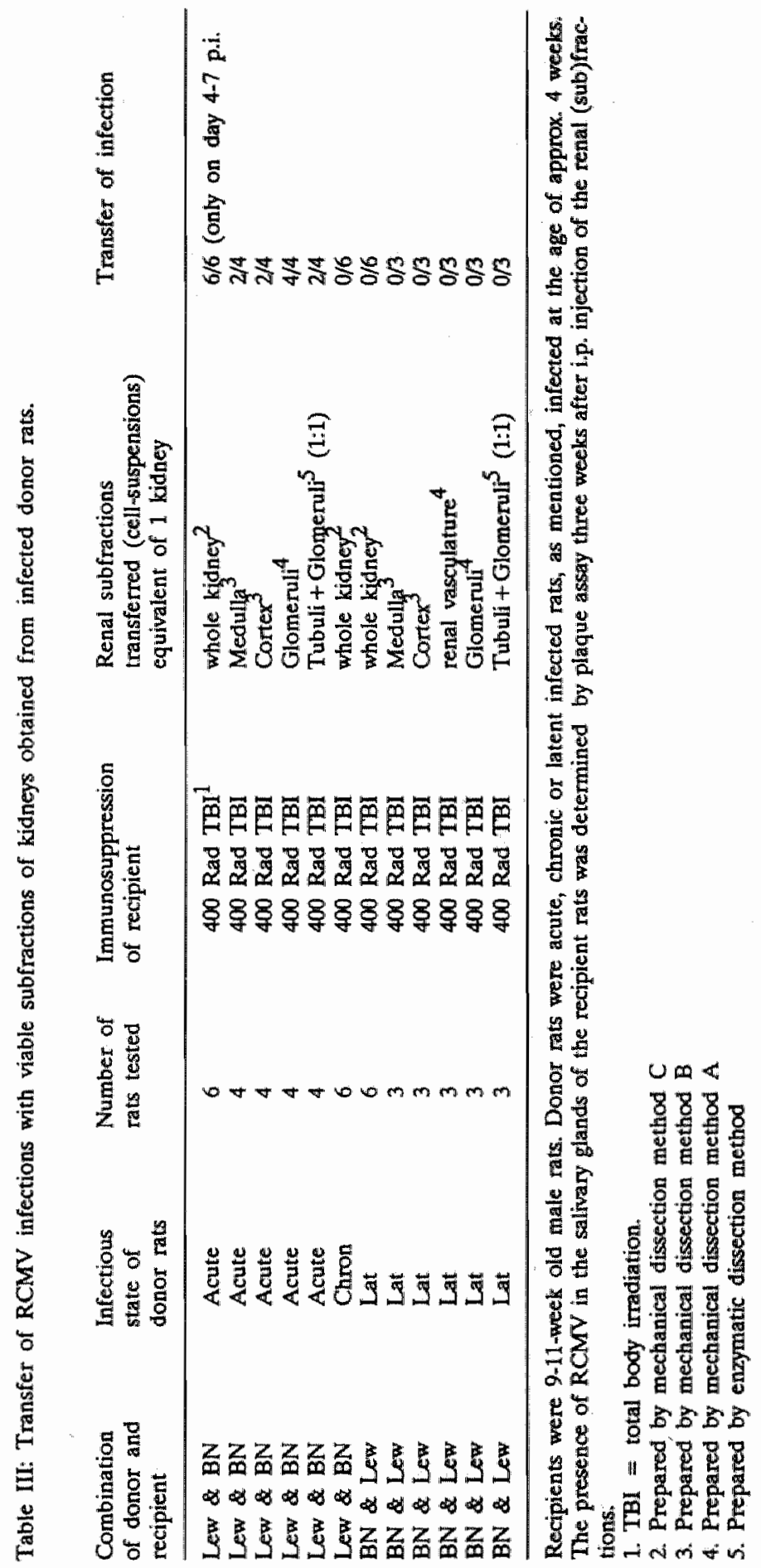


However, we could not transfer RCMV infection via blood, bloodderivatives, TD-cells, PEC or spleen cells, when these cells were obtained from chronically or latently infected donors, whereas renal grafts from these same donors readily did transfer RCMV infection (3). Thus, the observed organ specificity in the transfer of RCMV infection via complete viable organ grafts cannot be explained easily in these differences in the number of passenger leucocytes. There remains however the possibility of selective "homing" of some of these cells when infected, making them more or less fixed to organ specific structures.

Alternatively the latent virus is present in organ-specific cells, e.g. the renal tubular epithelium, or (glomerular) vascular endothelium.

This is supported by the fact that in human kidneys sometimes characteristic inclusion bodies have been observed histologically (11-13), and the viral genome has been demonstrated by in situ DNA hybridisation $(14,15)$. These concerned however manifestations of overwhelming disease in immunologically severely compromised individuals.

Many efforts to detect virus or viral antigens in kidneys of seropositive healthy donors as well as of cadaveric origin all but one exception (16), have failed so far $(12,17-18)$.

This corroborates the finding of immunohistochemical studies in the rat kidney, where cells expressing viral antigens were practically only found within the capsule and surrounding tissues of the kidney, and in some sporadically blood borne cells in the intertubular cappillaries in the acute phase of infection (Bruning et al. Natural history of RCMV infection; an immunohistochemical study. Submitted for publication).

Thus it seems likely that, although the virus apparently replicates in the capsule of the kidney in the acute phase of infection, the same period in which infective virus could also be detected in the blood, in the latent phase of infection the virus harbours somewhere within the kidney itself.

This is further supported by the fact that decapsulated kidneys of latently infected rats $(n=4)$ could transmit RCMV infection as readily as whole intact kidneys could (unpublished results). Unfortunately we (and others; 12, 17-18) were not able to detect viral antigens or the viral genome in these latently infected kidneys. The reason for this failure might be a matter of sensitivity of the methods employed, together with extremely low densities of viral antigens in the latently infected kidneys, or it might be that the "latent CMV-genome" has different antigenic epitopes than the virus in progress of replication. The explanation for the fact that renal cell suspensions of latently infected kidneys could not transfer RCMV infection, whereas whole intact kidneys of the same donor rats readily did so, is unclear. 
A possible explanation might be a "selective" loss of infected cells as result of the route of inoculation: Since the renal cell-preparations were not singlecell suspensions, it was necessary to inject these preparations i.p. rather than i.v. in order to avoid lethal complications. It can be argued that the effectivity of transfer of infection is less following the i.p. route (G. Bos; Personal Communication), e.g. because of the rapid clearance of these allogeneic cells by the peritoneal macrophages of the recipient, despite the immunosuppressive regimen administered (TBI). Peritoneal macrophages namely are relatively unsensitive to irradiation at dosages that effectively reduce the cellular immune responses (19-21), although some phagocytic functions are deteriorated (22).

In conclusion:

Although the observed organ specificity in the transfer of RCMV infections from latently or chronically infected donors seem to suggest that passenger leucocytes play a role in this infection transfer, peripheral blood leucocytes, spleen cells or thoracic duct cells obtained from these rats, and in quantities far exceeding the numbers of passenger leucocytes present in the heart or kidney were unable to transfer RCMV infection. It is therefore concluded that the latent RCMV genome either is harboured in organ-specific cells, or, when passenger leucocytes are infected, these cells become more or less fixed to these organs by "selective homing". More sophisticated methods will be needed to determine the exact localisation of CMV in these latently infected kidneys. 


\section{REFERENCES}

1. M. Ho, S. Suwansirikul, J.N. Dowling, L.A. Youngblood, J.A. Armstrong. The transplanted kidney as a source of cytomegalovirusinfection. N. Engl. J.Med. 1975; 293: 1109-1112.

2. R.F. Pailss, W.K. Long, RJ. Whitley, S. Soong, A. Diethelm, D.W. Reynolds, C.A. Alford Jr. Productive infection with CMV and HSV in renal transplant recipients: role of source of kidney. J. Inf. Dis. 1978; 137: 556.

3. J.H. Bruning, C.A. Bruggeman, C.P.A. wan Boven, P.J.C. van Breda-Vriesman. Passive transfer of Cytomegalovirus by cardiac and renal organ transplants in a rat model. Transplantation 1986; 41: 695-698.

4. J.H. Bruning, C.A. Bruggeman, C.P.A. van Boven. Enhancement of reactivation of latent Rat Cytomegalowirus by the combination of immunosuppression and the administration of allogeneic immunocomplement cells. Submitted for publication.

5. R van Schilfgaarde, P. Hermans, PJ.C. van Breda Vriesman. Role of mobile passenger lymphocytes in the rejection of renal and cardiac allografts in the rat. Transplantation 1980; 29(3): $209-213$.

6. R van Schilfgaarde, P. Hermans, Terpstra J.L., P.J.C. van Breda Vriesman. Influence of recirculating lymphocytes in the rejection of renal and cardiac allografts in the rat. Transpl. Proc. 1979; 11: 1485-1488.

7. C.A. Bruggeman, W.M.H. Debie, G. Grauls, G. Majoor, C.P.A. van Boven. Infection of laboratory rats with a New Cytomegalolike Virus. Arch of Virol. 1983; 1976: 189-199.

8. C.A. Bruggeman, H. Meiijer, F. Bosman, C.P.A. van Boven. Biology of rat Cytomegallovirus infection. Intervirology 1985; $24: 1-9$.

9. J.A. Bruning, W.H.M. Debie, P.H.J. Dormans, H. Meijer, C.A. Bruggeman. The development and characterization of monoclonal antibodies against rat cytomegalovirus induced antigens. Arch. Virol. 1987; 94: 55-70.

10. M.H. Julius et al. A rapid method for the isolation of functional thymus-dierived murine lymphocytes. Eur. J. Immunol. 1973; 3: 645.

11. D. Rifkind, N. Goodman, R.B Hill Jr. The clinical significance of CMV-infection in renal transplant recipient. Ann. Intern. Med. 1967; 66: 1116.

12. H.H. Balfour Jr, M.S. Slade, J.M. Kalis, R.J. Howard, R.L. Simmons, J.S. Najarian. Viral infections in renal transplant donors and their recipients: a prospective study. Surgery 1977 ; 81: $487-492$.

13. G.H. Fetterman G.H., F.E. Sherman, N.S. Fabrizio, F.M. Studnickie. Generalized cytomegalic inclusion disease of the newborn. Arch, Pathol. 1968; 86: 86-94.

14. J.S. Pagano. Diseases and mechanisms of persistent DNA virus infections: Latently and cellular transformation. J. Inf. Dis. 1975; 32: 209.

15. D. Myerson, R.C. Hackman, J.A. Nelson, D.C. Ward, J.K. Mc Dougal. Widespread presence of histologically occullt cytomegalowirus. Hum. Pathol. 1984; 15(5): 430-439.

16. E.V. Orsi, J.L. Howard, N. Batury, N. Bnde, S. Ribot, H. Eslami. High incidence of virus isolation from donor and recipient tissues associated with renal transplantation. Nature 1978; 272: $372-373$.

17. M. Ho. Cytonegalovirus: Biology and infection. New York, Plenum Medical Book Company 1982.

18. S. Naraqi, G.G. Jackson, O. Jonasson, M. Rubenis. Search for latent cytomegalovirus in renal allografts. Infect. Immun. 1978; 19(2): 699-703.

19. B. Geiger, R. Gallily. Effect of X-irradiation on various functions of murine macrophages. Clin. exp. Immunol. 1974; 16: 643-655.

20. E.E. Schwartz. The biologic basis of radiation therapy. Philadelphia, Lippincott, 1966, p. 132.

21. Sablonnière, J. Nicolas, Y. Nereux, J. Drouet. Effect of whole body irradiation on phagocytic activity of rat alteolar macrophages. Int. J. Radiat. Biol. 1983; 44: 575-584.

22. E.K Gallin, S.W. Green, J. Darden. Defective Fc-mediated phagocytosis in t-irradiated mouse peritoneal macrophages. Int. J. Radiat. Biol. 


\title{
CHAPTER IX
}

\section{ENHANCEMENT OF REACTIVATION OF LATENT}

RAT CYTOMEGALOVIRUS BY COMBINATION OF

IMMUNOSUPPRESSION AND ADMINISTRATION OF

ALLOGENEIC IMMUNOCOMPETENT CELLS

\author{
Johan Hendrik Bruning* \\ Catherina Alberta Bruggeman* \\ Cornelis Pieter Anton van Boven* \\ Peter Jacobus Cornelis van Breda Vriesman**
}

* Department of Medical Microbiology, University of Limburg, P.O. Box 616, 6200 MD Maastricht, The Netherlands. Department of Immunology, University of Limburg, P.O. Box 616, 6200 MD Maastricht, The Netherlands.

Transplantation 1988; accepted for publication 
Transplantation of kidneys from Lewis (LEW) rats latently infected with rat cytomegalovirus (RCMV) to allogeneic Brown Norway (BN) recipients invariably yielded reactivation of $\mathrm{RCMV}$, provided the recipients had been given $5 \mathrm{~Gy}$ of total body irradiation (TBI) just prior to grafting. Omitting TBI or using syngeneic irradiated recipients reduced the percentage of recipients in which reactivation of RCMV occurred to 50 and 26 per cent, respectively.

These findings might be explained by assuming that alloimmune reactions effected by passenger leucocytes present within the renal allograft, enhanced the reactivation of latent RCMV in immuno-compromised hosts.

This study was designed to test this hypothesis in latently infected BN rats. Alloimmune reactions in such rats, elicited by the infusion of allogeneic immunocompetent cells, or by the transplantation of allogeneic skin grafts, did not evoke reactivation of RCMV.

However, when latently infected $\mathrm{BN}$ rats received allogeneic immunocompetent cells in conjuction with TBI, reactivation readily occurred. On the other hand, TBI or immunosuppressive drugs alone were not able to reactivate latent RCMV.

These results suggest that in renal allotransplantation under immunosuppressive therapy, passenger leucocytes, via Graft-versus-Host Reactions (GvHR), play an important role in the occurrence of acute CMV infections.

\section{INTRODUCTION}

CMV infections occur in $50-90 \%$ of human renal allograft recipients who are maintained under immunosuppressive therapy (1-3). The majority of patients undergoing organ transplantation (approx. 65\%) have been previously infected with CMV and are carriers of latent virus (3).

Furthermore, the organ graft is probably infected as frequently as the average population from which these grafts are obtained $(1,4,5)$, adding to the risk of reactivation of pre-existing RCMV.

Although true primary infection (i.e. via "natural" courses) may occur in recipients of renal allografts, reactivation of latent virus within the recipients, or within their allografts, probably accounts for most of the infections (1). In most instances primary infection of the recipients is derived from the donated kidney and therefore is due to reactivation of latent virus $(1,6)$, although in blood transfusions administered around the time of transplantation 
may sometimes account for the infection $(1,7)$. In secondary $\mathrm{CMV}$ infections (i.e. recipients were seropositive prior to transplantation), the source of reactivated CMV is frequently the donated kidney as well (5). The mechanisms of these reactivations are poorly understood, but increasing evidence indicates that immunosuppressive therapy, rejection and/or GvHR in the recipients of organ grafts are involved to a significant extent.

Despite thorough perfusion procedures it appears to be inevitable that allogeneic immunocompetent cells will be introduced into recipients of renal allografts as passenger leucocytes present within the organ graft (8). These cells, either via GvHR or by activating immunomodulatory mechanisms, may play an important role in the reactivation of latent CMV present within the recipient or within the organ graft itself. In addition, leucocytes present in blood transfused prior to or during transplantation may act along the same pathway.

Extensive immunosuppressive regimens, although yielding long term renal allograft survival, will usually not prevent the occurrence of a temporary, mild rejection episode that may effect reactivation of latent CMV $(1,9,10)$. These immunosuppressive regimens by themselves may have enhancing effects on reactivation as well (11-14). Furthermore, nonspecific inflammatory reactions caused by the operation procedure may play a role (15, and this study). Since transplantation is generally combined with both immunosuppression and blood transfusions prior to, during, and/or after the operation, it is hard to determine in retrospect which factors were primarily responsible for CMV reactivation and infection of the graft recipients. In this study we have made an effort to unravel the complex interrelationships of the various factors that may influence reactivation, by testing them separately on latently infected rats.

\section{MATERIALS AND METHODS}

Animais

Inbred, Specific Pathogen-Free (SPF) Brown Norway (BN) and Lewis (LEW) rats were used. These rats were bred at the Department of Experimental Animal Services at the University of Limburg, Biomedical Centre, Maastricht, The Netherlands.

Vinus

The RCMV stock consisted of a pool of homogenates of salivary glands of acutely infected laboratory rats as described in a previous report (16).

Infection

Experimental infection of rats was established by intraperitoneal (i.p.) injection of $10^{3} \mathrm{PFU}$ of RCMV as described before (16). Infected rats were used as donors for renal grafts at least 6 
weeks after inoculation of the virus, when the infection had become chronic or latent. By that time all kidneys were latently infected $(14,15)$.

\section{Transplantation}

Orthotopic renal transplantations were carried out as described before (16). The recipient's left kidney was left in situ.

For skin grafting, full thickness skin from the back of LEW donor rats (approx. $3 \mathrm{~cm}^{2}$ ) was grafted aseptically to the back of latently infected BN rats by the fitted graft technique. Grafts wrere covered by an adhesive plaster for 8 days; after this time grafts were inspected daily and were considered to be rejected when complete necrosis of the surface epithellium was observed.

\section{Ninus assays}

Transfer of infection was tested by plaque assay of the recipients salivary gland homogenates 3 weeks affer transplantation (15).

\section{Immunosuppression}

Total body X-irradiation (TBI) was administered at the indicated dose just prior to transplantation as previously described (16).

As shown before, pretreatment of the recipients of a renall allograft with $5 \mathrm{~Gy}$ TBI resulted in allograft survival for at least 21 days.

Cyclosporin-A(Sandimmune ${ }^{\mathbf{R}}$,Sandoz ,Basel, Switzerland), Prednisone(Prednisoloni Natriisuccinas, Organon, Oss, The Netherlands), and azathioprine (Imuran ${ }^{\mathrm{R}}$, Wellcome, London, U.K.) were dissolved or diluted in salime to a concentration of $10 \mathrm{mg} / \mathrm{ml}$ just prior to use.

Cyclosporin (1.0 $\mathrm{mg} / \mathrm{kg}$ body weight), prednisone $(4 \mathrm{mg} / \mathrm{kg}$ ), and azathioprine ( $4 \mathrm{mg} / \mathrm{kg}$ ) were administered subicutaneously each day, for 21 days.

Irradiation of cells was done at a dose of $20 \mathrm{~Gy}$. X-rays were generated in a Phillips-Müller MG320 apparatus and administered at a dose of $150 \mathrm{rads} / \mathrm{min}$.

Peripheral blood leucocytes (PBL) and thoracic dwct leucocytes (TDL) were obtained as prewiously described (15).

Single cell suspensions of spleens were obtained by cutting the organs with scissors on a nylon gauze sieve (Monodur PA 100, Stokvis, Haarlem, The Netherlands), after freeing them of surrounding fat and capsules. The procedure was carried out under dropwise addition of cold working medium (RPMI), and the pieces were then carefully pressed through the sieve with a metal spatula. The resulting lymphoid cell suspension was washed once $\left(10^{*}, 250 \times \mathrm{g}\right.$ at $\left.4^{\circ} \mathrm{C}\right)$, resuspended in working medium and coumted in a Tris-buffered $2 \%(\mathrm{w} / \mathrm{V})$ solution of trypan blue. The percentage of trypan blue-positive cells was about 20 for splenocytes.

Statistical analysis was done using the Chi square test; differences were considered significant at the $\mathrm{p}=0.05$ level.

\section{RESULTS}

\section{Transplantations}

The effect of the transplantation procedure per se on the reactivation of latent RCMV transferred by the kidney graft was tested in a syngeneic transplantation 
model. Latently infected Lew kidneys were therefore inserted into syngeneic, non-immunosuppressed, male LEW recipients. Reactivation of the latent RCMV, and consequently transmission to the recipient, was tested by plaque assay of the recipient's salivary glands three weeks after transplantation.

As shown in Table I, reactivation occurred in 6 out of 14 recipients (43\%). When the recipients were immunosuppressed by $\mathrm{TBI}$, the reactivation rate fell to $29 \%$, although this difference was not statistically significant (Chisquare test). The introduction of an allogeneic Major Histocompatibility Complex (MHC) transplantation barrier had no significant effect on the reactivation rate either; reactivation of RCMV in latently infected LEW kidneys occurred in $50 \%$ of the recipients after insertion into unmodified $\mathrm{BN}$ rats. However, when $\mathrm{BN}$ recipients were immunosuppressed by TBI prior to transplantation, RCMV reactivation (and thus the infection transfer rate) rose to $100 \%$ (Table I). Previously, we demonstrated that reactivation and transmission of infection occurred within one week after transplantation (15).

Table I: Reactivation of latent RCMV in renal organ grafts

\begin{tabular}{lcccc}
\hline $\begin{array}{l}\text { Combinations } \\
\text { of donor and } \\
\text { recipient }\end{array}$ & $\begin{array}{l}\text { No. of } \\
\text { rats } \\
\text { tested }\end{array}$ & $\begin{array}{l}\text { X-irradiation } \\
(5 \mathrm{~Gy})\end{array}$ & \multicolumn{2}{c}{$\begin{array}{l}\text { No. of reactivations/ } \\
\text { no. tested }(\%)\end{array}$} \\
\hline LEW $\times$ LEW & 14 & no & $6 / 14$ & $(43 \%)$ \\
LEW $\times$ LEW & 7 & yes & $2 / 7$ & $(29 \%)$ \\
LEW $\times$ BN & 3 & no & $3 / 6$ & $(50 \%)$ \\
LEW $\times$ BN & 11 & yes & $11 / 11$ & $(100 \%)$ \\
\hline
\end{tabular}

Latently infected LEW kidneys were inserted orthotopically into either LEW or BN rats. For comparison, some of the recipients received immunosuppression by 0,5 Gy TBI.

Three weeks after transplantation reactivation of latent RCMV (and consequently, the infection of the recipients) was assessed by plaque assay of their salivary glands.

\section{Induction of reactivation in latently infected $B N$ rats}

For further analysis of the results obtained in the renal transplantation model, the effects of alloimmune responses and immunosuppression on the reactivation of RCMV were studied in latently infected, non-transplanted BN rats. For that purpose various immunosuppressive regimens were administered to latently infected BN rats. After three weeks homogenates of their salivary glands were tested for the presence of infectious RCMV by plaque assays. None of the immunosuppressive regimens attempted succeeded in evoking reactivation of RCMV (Table II). Besides salivary glands, spleen, liver, lung and kidney were tested for the presence of RCMV by plaque assay. Virus was not detected in any of these organs (data not shown). 
In a second set of experiments the effect of alloimmune responses on the reactivation of latent RCMV was tested.

Latently infected $\mathrm{BN}$ rats either received allogeneic immunocompetent cells intraveneously or allogeneic skin grafts. Neither infusion of allogeneic immunocompetent cells nor allogeneic skin grafts elicited reactivation of RCMV (Table III).

Finally, the effect of combined immunosuppression (TBI) and infusion of allogeneic immunocompetent cells on reactivation of the virus was tested.

As shown in Table IV, combination of X-irradiation and administration of allogeneic immunocompetent cells readily induced reactivation of RCMV in latently infected BN rats.

Infusion of $10^{7}$ allogeneic LEW Peripheral Blood Leucocytes (PBL) as well as $10^{7}$ LEW Thoracic Duct Leucocytes (TDL) readily induced reactivation of RCMV in 3 Gy irradiated, latently infected $B N$ rats.

Spleen cells appeared to be less effective than PBL or TDL, inducing reactivation in $33 \%\left(10^{7}\right.$ cells) or $67 \%$ ( $10^{8}$ cells) of the rats.

When the allogeneic barrier was omitted by infusing syngeneic cells into 3 Gy irradiated $\mathrm{BN}$ rats, reactivation did not occur.

Table II: The effect of various immunosuppressive regimens on the reactivation of RCMV in latently infected $\mathrm{BN}$ rats.

Inmunosuppressive

regimen
No. reactivations/ no. tested

\begin{tabular}{lc}
\hline None & $0 / 3$ \\
2 Gy Rad TBI' & $0 / 3$ \\
3 Gy Rad TBI & $0 / 3$ \\
4 Gy Rad TBI & $0 / 3$ \\
5 Gy Rad TBI & $0 / 3$ \\
6 Gy Rad TBI & $0 / 3$ \\
7 Gy Rad TBI & $0 / 3$ \\
8 Gy Rad TBI & $0 / 3$ \\
prednisone $8 \mathrm{mg} / \mathrm{kg} / \mathrm{day}$ & $0 / 3$ \\
azathioprine 4mg/kg/day & $0 / 3$ \\
prednisone + azathioprine $4 \mathrm{mg} / \mathrm{kg} / \mathrm{day}$ each & $0 / 3$ \\
cyclosporin 10mg/kg/day & $0 / 3$ \\
\hline
\end{tabular}

Latently infected $B N$ rats received immunosuppressive regimens at the indicated dose. Immunosuppressive drugs were administered subcutaneously each day for three weeks. Three weeks later reactivation was tested for by plaque assay of salivary gland homogenates.

w) $\mathrm{TBI}=$ total body irradiation 
Table III: The effect of alloimmune responses on the reactivation of RCMV in latently infected BN rats

No. reactivations/ no. tested

Inficion of cells

$\mathrm{TDL}^{2}\left(10^{7}\right)$

Whole blood $(2 \mathrm{ml})$

Spleen cells $\left(10^{8}\right)$

$0 / 4$

$0 / 4$

$0 / 4$

Grafting

Allogeneic skin graft

$0 / 4$

Latently infected $\mathrm{BN}$ rats either received allogeneic immunocompetent cells, or an allogeneic skin graft. Three weeks after intravenous infusion of the cells or grafting, reactivation was tested for by plaque assay of homogenates of the recipient's salivary glands.

1. TDL $=$ Thoracic duct leucocytes

Table IV: The effect of the X-irradiation and infusion of allogeneic immunocompetent cells on the reactivation of $\mathrm{RCMV}$ in latently infected $\mathrm{BN}$ rats

\begin{tabular}{llll}
\hline Infused cells (no) & $\begin{array}{l}\text { Donor } \\
\text { strain }\end{array}$ & $\begin{array}{l}\text { No. of reactivations/ } \\
\text { no. of rats tested }(\%)\end{array}$ \\
\hline PBL $^{2}\left(10^{7}\right)$ & LEW & $3 / 3$ & $(100 \%)$ \\
$\operatorname{TDL}^{2}\left(10^{7}\right)$ & $\mathrm{BN}$ & $0 / 3$ & $(0 \%)$ \\
Spleen cells $\left(10^{7}\right)$ & $\mathrm{LEW}$ & $3 / 3$ & $(100 \%)$ \\
Spleen cells $\left(10^{8}\right)$ & $\mathrm{BN}$ & $0 / 3$ & $(3 \% \%)$ \\
& $\mathrm{LEW}$ & $1 / 3$ & $(0 \%)$ \\
& $\mathrm{BN}$ & $0 / 3$ & $(67 \%)$ \\
\end{tabular}

Latently infected BN rats received allogeneic LEW immunocompetent cells from the sources and at the doses indicated.

Prior to intravenous infusion of the cells the BN recipients were immunosuppressed by 3 Gy total body irradiation. Three weeks after infusion of the cells reactivation was tested for by plaque assay of the recipient's salivary glands.

1. PBL $=$ Peripheral Blood Leucocytes

7. $T$ DL $=$ Thoracic Duct Leucocytes 


\section{DISCUSSION}

This study demonstrates that GvHR, in combination with immunosuppressive therapy, is effective in the reactivation of latent RCMV.

Immunosuppression per se was not capable of reactivating RCMV in latently infected $\mathrm{BN}$ rats. This observation is in agreement with the findings of Dowling et al. in patients with connective tissue diseases (11-12). The presence of infectious virus in buffy coats or urine from 86 patients could not be demomstrated, regardless of whether they were receiving corticosteroids or other immunosuppressive drugs.

Our finding that infusion of allogeneic immunocompetent cells in itself did not lead to reactivation of RCMV in latently infected BN rats is supported by the results from several independent studies concerning patients receiving multiple blood transfusions without concomitant immunosuppressive therapy (17-20). The risk of developing active infection in these studies was only $30 \%$ versus $76-92 \%$ in various documented renal transplant series (1-3).

The combination of immunosuppression by TBI and the infusion of allogeneic cells, however, was apparently effective in the reactivation of latent RCMV. In this model TDL and PBL appeared to be more effective in the induction of reactivation than spleen cells. Spleen cells, however, contain about $40 \%$ T-cells whereas TDL and PBL both contain approx. 80\% T-cells, suggesting that it is the T-cells, probably via GvHR, that are especially effective in the induction of reactivation.

In clinical practice the combination of GvHR and immunosuppression by TBI is predominantly seen in recipients of bone-marrow transplants, and it is especially in these patients that CMV reactivation-infections occur at high frequency (21-24).

In earlier studies in this rat model we have demonstrated that reactivation of virus in latently infected allogeneic kidneys after transplantation depended highly on the type of immunosuppression of the recipients (14). Reactivation of latent RCMV occurred in $100 \%$ of kidney allograft recipients treated with TBI and azathioprine-prednisolone, whereas reactivation of RCMV was observed only in $57 \%$ of cyclosporin-A treated recipients.

Further evidence that only the combination of extrinsic immunosuppression and GvHR is effective in reactivation of latent RCMV is derived from our finding that in $\mathrm{BN}$ rats with induced B-cell anergy to LEW class I MHC antigens $(25,26)$, reactivation occurs only in $40 \%$ of the recipients (14) upon grafting of a latently infected LEW kidney.

The kidney transplantation experiments demonstrated that even after omission of both alloimmune responses and immunosuppression, as attained with syn- 
geneic transplantations (Table I), a high incidence of reactivation of latent RCMV in the renal graft still occurred. This suggests that merely the operation procedure, e.g. by nonspecific inflammatory reactions, may elicit reactivation of latent RCMV. The reduction of the reactivation rate observed after addition of immunosuppression in this syngeneic combination, can possibly be ascribed to reduction of nonspecific inflammatory reactions by the $\mathrm{X}$-irradiation. At the dose applied, $\mathrm{X}$-irradiation dramatically reduces the number of peripheral leucocytes, including polymorphonuclear leucocytes (27).

In this study rejection phenomena appeared not to have significant effects on the reactivation of RCMV. In man, no definitive data on the role of rejection in the reactivation of latent CMV are available either, but such effect is suspected: Pass et al. (28) reported a significantly higher incidence of CMV reactivation after grafting of cadaveric kidneys (76\%) than after grafting of kidneys obtained from living-related donors (33\%). This difference was ascribed to stronger HvG (rejection) reactions towards cadaveric transplants than to grafts from living-related donors. The data presented in this study and the clinical data cited suggest a synergistic effect of GvHR and immunosuppression on the occurrence of CMV reactivation-infections after allogeneic transplantation.

\section{ACKNOWLEDGEMENTS}

The authors wish to thank Ilse Heutz and Jeannette Cornelissen for performing kidney transplantations, Mieke Henfling for the thorac duct cannulations, Dr. Gerard Majoor for helpful discussions and critical review of the manuscript, and Mrs. Fia Claus-Hahn, Mrs. Ilse Gronenschild and Mrs. Lilian Kreusch for their secretarial assistance.

This study was supported by grant (no. C83-399) from the Dutch Kidney Foundation (NSN). 


\section{REFERENCES}

1. M. Ho. Cytomegalovirus, Biology and Infection. 1982. Plenum Medical Book Company, New York and London.

2. Summary of a workshop on CMV infections during organ transpiantation. J. Infect. Dis. 1979; 139: 728 .

3. RH. Rubin, N.E. Tolkoff-Rubin, D. Oliver, et al. Multicenter seroepidemiologic study of the impact of cytomegalovirus infection on renal transplantation. Transplantation 1985; 40: 243.

4. E.V. Orsi, J.L. Howard, N. Baturay, et al. High incidence of virus isolation from donor and recipient tissues associated with renal transplantation. Nature 1978; 272: 372.

5. J.E Grundy, M. Super, S. Lui, P. Sweny, P.D. Griffith. The source of CMV in seropositive renal allograft recipients is frequently the donor kidney. Transplant. Proc. 1987; 19:2126.

6. R.L. Simmons, H. Lopez, H.A. Balfour Jr., J.M. Kallis, L.C. Ratazzi, J,S. Najarian. Cytomegalovirus: Clinical virological correllations in renal transplant recipients. Ann. Surg. 1974; 180; 623.

7. R.F. Betts. The relationship of epidemiology and treatment factors to infection and allograft survival in renal transplantation. In: Birth defects 1984. Original article series vol. 20, nr. 1 : 87-99.

8. R. van Schilfgaarde, P. Hermans, P.J.C. van Breda Vriesman. Influence of recirculating lymphocytes on the rejection of first-set rat organ allografts. Transplant. Proc. 1979; 11: 1485.

9. C. Lopez, R.L. Simmons, S.M. Mauer, J.S. Najarian, S.A. Good. Association of renal allograft rejection with virus infections. Am. J. Med. 1974; 56: 280.

10. J.D. Hamilton. Cytomegalovirus and Immunity. In: Melnick, J.L. (Ed.) Monographs in Wirology 12th ed. Karger Press, Londion (1984).

11. J.N. Dowling, A.R. Saslow, J.A. A.rmstrong, M. Ho. Cytomegalovirus infection in patients receiving immunosuppressive therapy for theumatologic disorders: J. Infect. Dis. 1976; 133: 399

12. J.N. Dowling, A.R. Saslow, J.A. Armstrong, et al. The relationship of immunosuppression to CMV infection. Yale J. Biol. Med. 1976; 49: 77.

13. M.J. Bia, W. Andiman, K Gaudio, et al. Effect of treatment with cyclosporine versus azathioprine on incidence and severity of cytomegalovirus infection post transplantation. Transplan. tation 1985; 40: 610 .

14. J.H. Bruning, C.A. Bruggeman, P.J.C. van Breda-Vriesman. The transfer of CMV infection via latent infected renal allografts and the role of various immunosuppressive regimes on its reactivation. Transplantation (in press).

15. J.H. Bruning, C.A. Bruggeman, C.P.A. van Boven, P.J.C. van Breda-Vriesman. Passive transfer of cytomegalovirus by cardiac and renal organ transplants in a mat model. Transplant. 1986; 41: 695 .

16. C.A. Bruggeman, W.M.H. Debie, G. Grauls, G. Majoor, C.P.A. van Boven. Infection of laboratory rats with a new cytomegalo-like virus. Arch. Virol. 1983; 76: 189.

17. G.R.G. Monif, G.I. Daicoff, L.L. Flory. Blood as a potential wehicle for the cytomegaloviruses. Am. J. Obstet. Gynec. 1976; 126; 445.

18. G.A. Nankervis. Comments on CMV infections in renal transplant patients. Yale J. Biol. Med. 1976; 49; 27.

19. A.M. Prince, W. Szmuness, S.J. Millian, D.S. Davis. A serologic study of cytomegalovirus infections associated with blood transfusions. New Eng. J. Med. 1971; 284: 1125.

20. D.P. Stevens, L.F. Barker, A.S. Ketcham, H.M. Meyer Jr. Asymptomatic cytomegalovirus infection following blood transfusion in tumor surgery. J. Am. Med. Ass. 1970; 211: 1341.

21. D.J. Winston R.P. Gale, D.V. Meyer, L.S. Young. Infectious complications of human bone marrow transplantation. Medicine 1979; 58: 1

22. J.D. Meyers, N. Fournoy , E.D. Thomas. Risk factors for cytomegalowirus infection after human marrow transplantation. J. Infect. Dis. 1986; 153: 478.

23. F.R. Appelbaum, J.D. Meyers, A. Fefer et al. Nonbacterial nonfungal pneumonia following marrow transplantation in 100 identical twins. Transplant. 1982; 33; 265 .

24. W. Miller, P. Flynn, J. McCulbugh, et al. Cytomegalovirus infection after bone marrow transplantation: An association with acute graft-vs-host disease. Blood 1986; 67: 1162 .

25. G.D. Majoor, M.J.W.H. v.d. Gaar, L.F.M. Vlek, P.J.C. van Breda Vriesman. The role of antibody in rat renal allograft rejection. Transplant. 1981; 31: 369.

26. G.D. Majoor, P.J.C. van Breda Vriesnan. Induction B Cell Tollerance in rats by large doses of allogeneic erythrocytes. Transplant. 1986; 42: 292. 
27. L.F. Ford, R.C. Atkins. Specific Unresponsiveness of recirculating Lymphocytes after Exposure to Histo compatibility Antigen in F, Hybrid Rats. Nature New Biology 1971; 234: 178.

28. R.F. Pass, W.K. Long, R.J. Whitley, S.J. Soong, A.G. Diethelm, D.W. Reynolds, C.A. Alford Jr. Productive infection with CMV and HSV in renal transplant recipients: Role of source of kidney. J. Infect. Dis. 1979; 137: 556. 


\title{
CHAPTER $\mathrm{X}$
}

\section{THE TRANSFER OF CMV INFECTION IN RATS}

BY LATENTLY INFECTED RENAL ALLOGRAFTS

AND THE ROLE OF VARIOUS IMMUNOSUPPRESSIVE

REGIMENS ON VIRUS REACTIVATION

\author{
J.H. Bruning* \\ C.A. Bruggeman* \\ P.J.C. van Breda Vriesman**
}

* Department of Medical Microbiology, University of Limburg, P.O. Box 616,6200 MD Maastricht, The Netherlands. Department of Immunology, University of Limburg, P.O. Box $616,6200 \mathrm{MD}$ Maastricht, The Netherlands.

Transplantation 1988; accepted for publication 
Prospective studies have shown cytomegalovirus (CMV) infections to occur in 50-90\% of renal allograft recipients maintained on immunosuppressive therapy $(1,2)$. The majority of the patients and donors are seropositive prior to transplantation. Although reactivation of the recipient"s latent virus may cause the infection, the major cause of the CMV infections is considered to be brought about by reactivation of latent virus in the donor kidney $(1,2$, 3). CMV infections can be transmitted to sero-negative recipients by several routes (1). In clinical practice, however, it is more likely that in these instances the infection is derived from the donor kidney too (3). These "primary" infections can therefore be considered as reactivation infections as well.

The exact mechanism of reactivation is poorly understood. However, increasing evidence indicate that immunosuppressive therapy (4), rejection (5) and/or Graft vs. Host (GvH) (6) reactions trigger reactivation of latent CMV.

Recently, we characterized a rat cytomegalovirus (RCMV) and showed that latent infections could be transmitted with well perfused kidney and heart transplants (7). Reactivation was favoured by an allogeneic barrier and Xirradiation of the host (7). In this study we examined the effect of various types of immunosuppression on the reactivation of RCMV in recipients of latently infected renal allografts.

For this purpose latently infected kidneys from Lewis (Lew) rats were transplanted into Brown Norway (BN) rats, as described previously (7). Lew rats were infected intraperitoneally with $10^{5}$ plaque forming units of RCMV at least six weeks prior to transplantation. The Lew kidneys were considered latently infected when antibodies to RCMV were demonstrable serologically and infectious virus could not be detected in any organ but for the salivary glands (8) using standard virus plaque assays (9). The donor kidneys were perfused and transplanted into $\mathrm{BN}$ rats which were either tolerized or immunosuppressed. $\mathrm{BN}$ recipients were made tolerant to class I MHC antigens by inducing B-cell anergy through repeated infusions of Lew erythrocytes, thus assuring prolonged survival of Lew kidneys (10). Immunosuppressive regimens consisted of $5 \mathrm{~Gy} \mathrm{X}$-irradiation at the time of transplantation, cyclosporin- $\mathrm{A} 10 \mathrm{mg} / \mathrm{kg} /$ day subcutaneously (s.c.), or azathioprine and prednisolone both $4 \mathrm{mg} / \mathrm{kg} /$ day s.c. respectively. These regimens prevent rejection of the renal allografts over a period of 3 weeks as shown histologically by the absence of cellular infiltrates. In contrast, in the tolerized $\mathrm{BN}$ recipients low grade rejection does occur as indicated by an interstitial mononuclear infiltrate in the renal allografts after 3 weeks, although survival of the graft is well over 3 weeks (10). Three weeks after transplantation the $\mathrm{BN}$ rats were sacrificed and reactivation-infection in the recipients was determined by virus plaque assay of their salivary glands (7). 
The main finding of the present study is that the immunosuppressive regimen administered in order to prevent renal allograft rejection influences significantly the occurrence of RCMV reactivation (table 1). Reactivation of latent RCMV occurred in $100 \%$ of the recipients treated with total body X-irradiation and azathioprine-prednisolone, whereas reactivation of RCMV was observed in only $57 \%$ of the cyclosporin treated recipients $(p<0.04)$. In the recipients with induced B-cell anergy to class I MHC antigens reactivation occurred in $40 \%$.

Table I: Effect of immunosuppression of BN recipients on the reactivation of latent RCMV within renal Lewis grafts

\begin{tabular}{clcc}
\hline $\begin{array}{l}\text { Experimental } \\
\text { group }\end{array}$ & $\begin{array}{l}\text { Immunosuppression } \\
\cdot\end{array}$ & $\begin{array}{l}\text { No. of rats } \\
\text { tested }\end{array}$ & $\begin{array}{l}\text { No.(\%) ofRCMV positive } \\
\text { salivary glands }\end{array}$ \\
\hline 1 & $\begin{array}{l}\text { B-cell anergy to class I MHC antigens } \\
2\end{array}$ & 5 & $2(40 \%)$ \\
3 & cyclosporin $^{*}$ & 7 & $4(57 \%)$ \\
4 & prednisone/azathioprine $^{\text {total body X-irradiation }}{ }^{\text {a }}$ & 5 & $5(100 \%)$ \\
\hline
\end{tabular}

Legend to Table I:

Donor rats were latently infected 1 ew rats, jnoculated with RCMV at the age of approx. 4 weeks, at least 6 weeks prior to transplantation. Well perfused kidneys were transplanted into $B N$ rats. BN recipients were 9-11 weeks old male rats, immunosuppressed specifically or aspecifically as indicated, and sacrificed 3 weeks after transplantation at which time the salivary glands were assessed for RCMV.

- $10^{10}$ Lew erythrocytes administered every 2 weeks, $3 x$ prior to transplantation.

- $10 \mathrm{mg} / \mathrm{kg} /$ day s.c.

c $4 \mathrm{mg} / \mathrm{kg} / \mathrm{day}$ s.c. each.

a 5 Gy of total body X-irradiation.

Statistical relevance according to Fisher exact test.

Group 1 compared to $4: \mathrm{p}<0.02$

Group 2 compared to $4: \mathrm{p}<0.04$

The observed difference in reactivation between the azathoprine-prednisolone and cyclosporin treated recipients agrees with the experience in human renal transplantation. The introduction of cyclosporin-A therapy has brought about a sharp decrease in the incidence of CMV infections. The present results suggest that $\mathrm{GvH}$-like reactions mediated by passenger lymphocytes residing in the perfused renal allografts (12) play a role in the reactivation of latent RCMV. As shown previously (7), the reactivation of latent RCMV in X-irradiated allogeneic rat recipients is better accomplished with renal compared to cardiac allografts; compared to the heart kidneys have a greater number of passenger lymphocytes and elicit greater $\mathrm{GvH}$-reactions in immuno-incompetent allogeneic hosts (13). The present findings provide further corroboration. 
Although the immunosuppressive regimens used all suppress the T-cell response of the host, as shown by the absence of signs of rejection in Lew renal allografts three weeks post operatively, compared to azathioprine-prednisolone treatment cyclosporin-A suppressed $\mathrm{GvH}$ reactions more effectively $(14,15)$. In the recipients with induced B-cell anergy to class I MHC antigens the prompt rejection of the Lew passenger lymphocytes (16) will prevent a GvH reaction. The significant reduction in the number of RCMV reactivation in these recipients as compared to the $\mathrm{X}$-irradiated and azathioprine-prednisone treated recipients therefore provides additional evidence for a role of $\mathrm{GvH}$ reaction in initiation of $\mathrm{CMV}$ reactivation.

\section{ACKNOWLEDGMENTS}

We thank Wineke Vlek, Ilse Heuts and Jeanette Cornelissen for their technical assistance. We also thank Cees van Boven for critical reviewing the manuscript and Ilse Gronenschild for her secretarial expertise.

This work was supported by the Dutch Kidney Foundation (grant nr. C83399). 


\section{REFERENCES}

1. M. Ho. Cytomegalovirus, Biology and Infection. Plenum Medical Book Company 1982, New York and London.

2. R.H. Rubin, N.E Tolkoff-Rubin, D. Oliver er al. Multicenter seroepidemiologic study of the impact of cytomegalowirus infection on renal transplantation. Transplantation 1985; 40: 243.

3. R.F. Pass, W.K. Long, R.J. Whitley, S.J. Soong, A.G. Diethelm, D.W. Reynolds, C.A. Alford Jr. Productive infection with CMV and HSV in renal transpllant recipients: Role of source of kidney. J Inf Dis 1987; 137: 556.

4. J.N. Dowling, A.R Saslow, J.A. Armstrong, M. Ho. CMV infection in patients receiving immunosuppressive therapy for theumatologic disordens. J Inf Dis 1976; 133: 399.

5. M. Ho, J.N. Dowling, J.A. Armstrong, S. Suwansirikul, B. WW, L.A. Youngblood, A. Saslow. Factors contributing to the risk of $\mathrm{CMV}$ infection in patients receiving renal transplants. Yale J Biol Med 1976; 49: 17.

6. J.N. Dowling e.a. Enhancement of HCMV infection during GvH reaction. J. Infect Dis 1977; 135: 990 .

7. J.H. Bruning, C.A. Bruggeman, C.P.A. van Boven, P. van Breda Vriesman. Passive transfer of CMV by cardiac and renal organ transplants in a rat model. Transplantation 1985; $41: 695$.

8. C.A. Bruggeman, H. Meijer, F. Bosman, C.P.A. van Boven. Biology of rat Cytomegalovirus infection. Intervirology $1985 ; 24: 1$.

9. C.A. Bruggeman, W.M.H. Debie, G. Grauls, G. Majoor, C.P.A. van Boven. Infection of laboratory rats with a new cytomegalo-like virus. Arch Virol 1983; 76: 189.

10. G.D. Majoor, P.J.C. van Breda Vriesman. Requirement for both MHC and non-MHC antigens residing on the same erythrocytes for donor erythrocyte mediated prolongation of rat renal allograft survival. Transplantation 1986; 41 : 92 .

11. J.S. Najarian, D.S. Fryd, M. Strand e.a. A single Institution, Randomised Prospective Trial of Cyclosporine versus Azathioprine - Antilymphocyte Globulin for Immunosuppression in Renal Allograft Recipient. Ann Surg 1985; 201: 142.

12. R. van Schilfgaarde, P. Hermans, J.L. Terpstra, P.J.C. van Breda Vriesman. Role of mobile passenger lymphocytes in the rejection of renal and cardiac allografts in the rat. Transplantation 1980; 29: 209.

13. R. van Schilfgaarde, P. Hermans, P.J.C. van Breda Vriesman. Influence of recirculating lymphocytes on the rejection of first set rat organ allografts. Transplantation 1979; Proc XI: 1485.

14. E.M. Shevach. The effects of cyclosporin-A on the immune system. Ann Rev Immunol 1985; 3: 397.

15. S. Ferrini, A. Moretta, R. Biassoni, A. Nicolin, L. Moretta Cyclosporin A inhibits IL-2 production by all human T-cell clones having this function. Clin Immunol Immunopathol 1986; 38: 79.

16. G.D. Majoor, M.J. de Gaar, L.F.M. Vlek, P.J.C. van Breda Vriesman. The role of antibody in rat renal allograft rejection I. Transplantation 1981; 31: 369 . 


\title{
CHAPTER XI
}

\section{THE EFFECT OF CYTOMEGALOVIRUS INFECTION}

\section{ON RENAL ALLOGRAFT FUNCTION IN A RAT MODEL}

\author{
Johan Hendrik Bruning* \\ Catherina Alberta Bruggeman* \\ Peter Jacobus Cornelis van Breda Vriesman**
}

* Department of Medical Microbiology, University of Limburg,

P.O. Box 616, 6200 MD Maastricht, The Netherlands.

** Department of Immunology, University of Limburg, P.O. Box 616, 6200 MD Maastricht, The Netherlands.

Transplantation 1988; accepted for publication 


\section{SUMMARY}

The effect of rat cytomegalovirus (RCMV) infection on the function and survival of renal allografts was studied in inbred rat strains. Experimentally induced acute or chronic (primary) infections, or reactivation-infections from latently infected donor kidneys were assessed on its effects on renal allograft function and/or survival by frequent determination of recipients blood urea, and urinary protein loss.

When unmodified Brown Norway (BN) recipients of a Lewis (LEW) renal graft were acutely infected with RCMV, no statistical differences were noted in acute rejection, in comparison to uninfected recipients, as determined by blood urea levels. Furthermore, in BN rats with a previously established B-cell anergy to Lew MHC class I antigens, acute RCMV infections had no effect on chronic renal allograft rejection as determined by renal allograft function. During this observation period the experimentally induced acute RCMV infection became chronic at approximately 2 weeks post infection, and latent approximately 6 weeks post infection, which had no effect on renal allograft function either when compared to uninfected controls.

In cyclosporin-A treated recipients of latently infected LEW kidneys, neither the presence of this latent virus in the allograft nor its reactivation and transfer to the recipient, had any effect on renal allograft function and survival.

These results suggest that, at least in the rat model used, CMV infection has no direct effect on renal allograft function, neither in favourable nor in unfavourable respect. In the rat model CMV glomerulopathy does not seem to play a role in rejection of renal allografts.

\section{INTRODUCTION}

Active CMV infections are frequently encountered in immunocompromised individuals such as recipients of organ allografts that are maintained under immunosuppressive therapy (1-4). Whereas in immunocompetent, immunologically mature individuals CMV infections usually remain unnoticed, morbidity and even mortality directly or indirectly caused by CMV infections, form a serious problem under the specific conditions associated with organ transplantation (5-6). CMV-related mortality in the transplant recipient is directly related to the type and degree of immunosuppression required for prevention of organ rejection; the lowest mortality is seen in renal transplant recipients $(2 \%)$ and the highest in bone marrow transplant recipients (40\%) (7). Although the 
mortality related to CMV infection is relatively low in renal transplant recipients, these infections have frequently been associated with impairment of the renal graft function and with diminished graft survival $(5,8-11)$. The question is however whether CMV infections injure the renal, particularly glomerulary vasculature as part of the so called CMV glomerulopathy (12-15), e.g. by modulation of MHC-antigen expression or expression of CMV antigens on infected endothelial cells (16-17), and by circulating immune-complexes (1215), or that the CMV infections are secondary to increases in immunosuppressive therapy used for treating vascular rejection.

The available clinical data from several reports of both retrospective and prospective nature are frequently conflicting and from it no clearcut conclusions can be drawn $(2,8,10,18-20)$. In most instances factors that may influence the results are so numerous and complexely interrelated, that a causative role of (Human) CMV infection in the final outcome of renal graft survival and/or function cannot be determined.

Therefore this issue is studied in a well defined rat model with standarized models of renal allograft rejection, using a rat cytomegalovirus (RCMV) (21-23).

\section{MATERIALS AND METHODS}

Animals

Inbred male Brown Norway (BN) and Lewis (Lew) tats from our awn colonies were used. These rats were bred under specific-pathogen-free (SPF) conditions at the Department of Experimental Animal Services of the University of Limburg, Biomedical Centre, Maastricht, The Netherlands.

\section{Virus and viral antigens}

In our studies we used an isolate of a wild rat cytomegalovirus (RCMV) strain as described before (21-23). The wirus stock consisted of homogenates of salivary glands of four-week-old rats inoculated i.p. with $10^{5}$ plaque-forming units (PFU) of virus. For the detection of viral antigens a panel of anti RCMV mouse monoclonal antibodies and rat hyperimmune serum was used in an indirect immunoperoxidase assay on paraffin embedded tissue sections, as described in detail previously $(24 \cdot 25)$.

\section{Infection}

Experimental (acute) infections were established by inoculating 4-5 weeks old rats i.p. with $10^{4}$. $10^{5}$ PFU of RCMV. In this study we discriminated between latently and chronically infected animals merely by the absence or presence of RCMV in the salivary glands six weeks after infection, as determined by plaque-assay of the homogenates of a surgical biopsy of the salivary glands. Since the main criterion of latency is the absence of infective virus, and at six weeks after infection all organs including the kidney were virusnegative upon culture, we designated these organs as latently infected.

The presence of latent virus within these kidneys is $100 \%$ as has been demonstrated befiore in transfer studies (26). 
Virus assays

Quantitative assays for infectious virus were performed by plaque assay as described before (22).

Virus antibodies

Serum antibody titers to RCMV were determined by an enzyme-linked immunosorbent assay as described before (22).

\section{Experimental models of renal allograft rejection}

Well perfused Lew kidneys were obtained from normal rats or rats chronically infected with $R C M V$, and were transplanted orthotopically into bilaterally nephrectomized $B N$ rats according to standard techniques (27); renal allograft function was monitored by measuring the serum urea concentration and 24 hour urinary protein excretion. Unmodified recipients of Lew kidneys were sacrificed when the serum urea concentration exceeded $400 \mathrm{mg} / \mathrm{ml}$ of serum, and immunosuppressed BN recipients were sacrificed at approximately 40 days post transplantation; presence of rejection in Lew renal allografts was assessed histologically in a semi-quantitative fashion scoring separately interstitial, arterial, glomerular and peritubular capillary inflammatory changes. (28). Prolonged Lew renal allograft survival was brought about by manipulating the $B N$ recipients in two fashions. In the first model $B N$ recipients were made tolerant to Lew class I antigens by multiple transfusions of highly purified Lew erythrocytes (Lew-E) prior to surgery. Lew kidneys inserted into such tolerized BN rats experience a transient rejection episode at 2 weeks postoperation, followed by low grade wascular rejection with stable renal function up to 50 days postoperation (29). Alternatively BN recipients of Lew kidneys were treated with cyclosporin A, $10 \mathrm{mg} / \mathrm{kg} / \mathrm{day}$ s.c., for 21. days commencing on the day of transplantation. Renal function, judged by the serum urea concentrations of normal Lew rats or Lew rats latently infected with RCMV was not influenced by this therapeutic regimen.

In preliminary studies it was found that the natural course of RCMV infection in cyclosporin-A treated rats, in terms of virustiters and appearance of viral antigens in the various organs, was unchanged when compared to the infection course in unmodified rats, except for sero-conversion to RCMV antigens which did not take place in the cyclosporin-A treated rats (unpublished data).

\section{Statistical analysis}

Differences in blood urea levels and urinary protein excretion were statistically analysed using the Mann-Whitney test.

Differences were considered significant when $p \leq 0.05$.

\section{RESULTS}

\section{Effect of acure RCMV infection on acute and modified renal allograft rejection}

The effect of acute RCMV infection on acute renal allograft rejection was assessed by injecting $10^{5}$ PFU of RCMV intraperitoneally (i.p.) to BN recipients of Lew kidneys at the time of transplantation. Both uninfected and RCMV treated $\mathrm{BN}$ hosts rejected the Lew kidneys in an identical fashion functionally (fig. 1) and histologically. When kidney sections were stained for RCMV antigens only occasionally mononuclear cells were seen in some glomerular cap- 
illaries. The effect of acute RCMV infection on chronic renal allograft rejection was assessed by giving $10^{5}$ PFU of RCMV i.p. to Lew-E tolerized BN recipients of Lew renal allografts at the time of a transient rejection episode at 14 days postoperation. This acute RCMV infection did not influence the renal function or proteinuria of Lew kidneys residing in tolerized $\mathrm{BN}$ rats (fig. $2 \mathrm{a}$ en b). The histological changes - interstitially, glomerularly and in the peritubular capillaries - in RCMV infected rats as compared to non-infected controls were comparable at the time of sacrifice at 40 days postoperation, and no RCMV antigens were demonstrable immunohistochemically in the infected kidneys.

Fig. 1: The effect of RCMV-infection on acute renal graft rejection

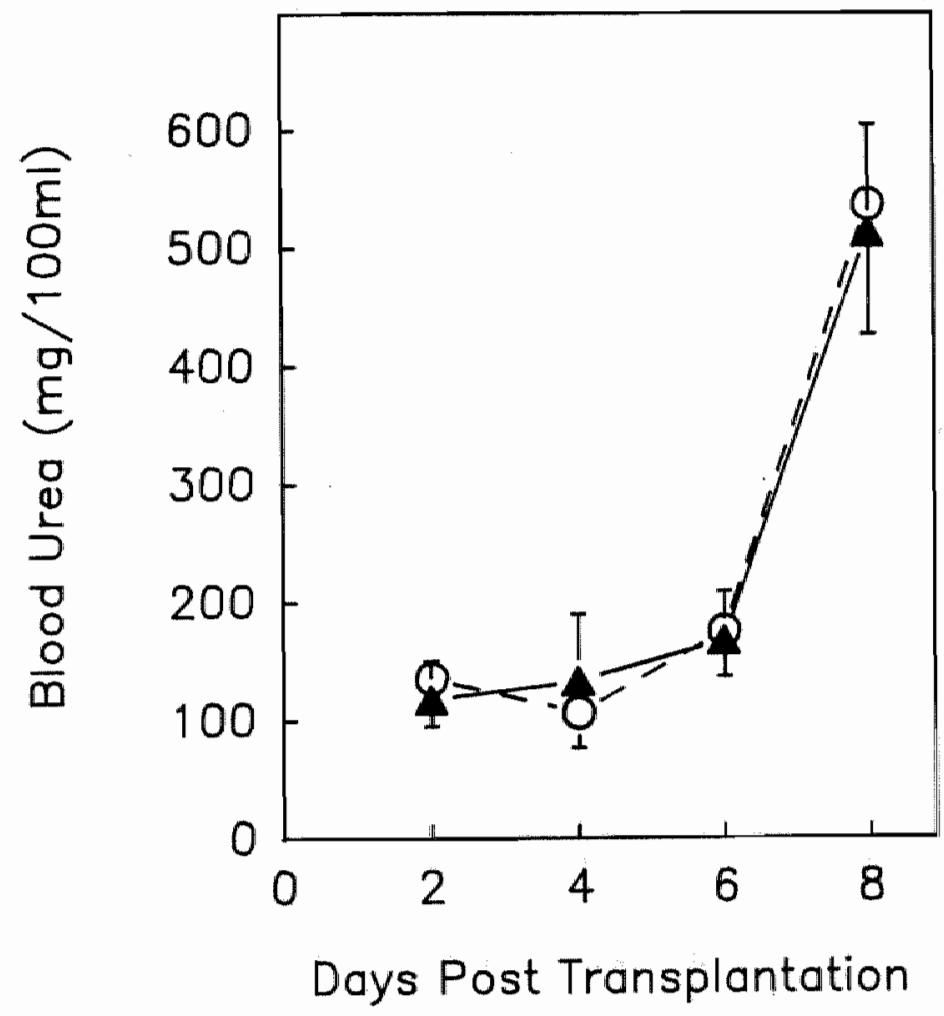

Recipients were unmodified male BN rats, 9-11 weeks of age. Both kidneys of the recipients were removed and a LEW renal allograft was inserted orthotopically. Donors were 9-11-week old LEW rats.

Acute RCMV infection was established by i.p. injection of $10^{5}$ PFU of RCMV at the day of transplantation.

Blood samples were taken daily by orbital puncture and blood urea levels were determined to assess acute vascular rejection.

Dotted line with open circles represent blood urea levels of uninfected control rats $(n=8)$; solid line with triangles represent blood urea levells of infected experimental group $(n=8)$. Bars indicate standard deviations. 
Effect of latent CMV infection of the donor kidney on renal allograft function in modified $B N$ recipients

Latently infected Lew kidneys $(n=2)$ which were derived from chronically $R C M V$-infected donors, were transplanted into Lew-E tolerized $B N$ recipients. These renal allografts showed a postoperative renal function indistinguishable from noninfected controls in terms of the serum urea concentration and proteinuria (Fig. 2a); graft histology at the time of sacrifice at 40 days postoperation was identical. No RCMV antigens were demonstrable immunohistochemically in these two kidneys. In both recipients IgG antibody to RCMV was demonstrable at the time of sacrifice, and the salivary gland was viruspositive in one of them. Latently infected Lew kidneys $(n=5)$ and normal Lew kidneys $(n=9)$ transplanted into cyclosporin-A treated $B N$ recipients showed comparable renal function (Fig. 2c,d). In both groups of rats, progressive, but comparable degrees of proteinuria developed after cessation of cyclosporinA therapy at 21 days after transplantation; at the time of sacrifice 40 days post-operatively both groups of Lew-kidneys had identical interstitial and glomerular changes, indicative of interstitial and vascular rejection.

None of the BN recipients of latently infected Lew kidneys developed antiRCMV antibodies during the whole observation period. At the time of sacrifice (40 day post transplantation) no RCMV antigens were demonstrable both in donor kidneys and in the recipients' salivary glands.

\section{DISCUSSION}

The main findings of this study are threefold. Firstly, acute RCMV infections do not influence Lew renal allograft function and survival in unmodified and Lew-E tolerized BN recipients. Since in BN rats acute RCMV infections become chronic within 2 weeks and latent at approximately 6 weeks post infection $(26,30)$, it can secondly be concluded that chronic or latent RCMV infections have no effect on renal allograft function and survival either as shown in the Lew-E tolerized BN recipients. Thirdly, the pattern of rejection of latently infected Lew kidneys does not differ from uninfected controls when transplanted into Lew-E tolerized on cyclosporin-A treated BN recipients.

These results do not support a role of CMV glomerulopathy in the rejection of rat renal allografts as was suggested by many investigators as a possible mechanism of diminished graft survival in man $(12-15,31)$. 


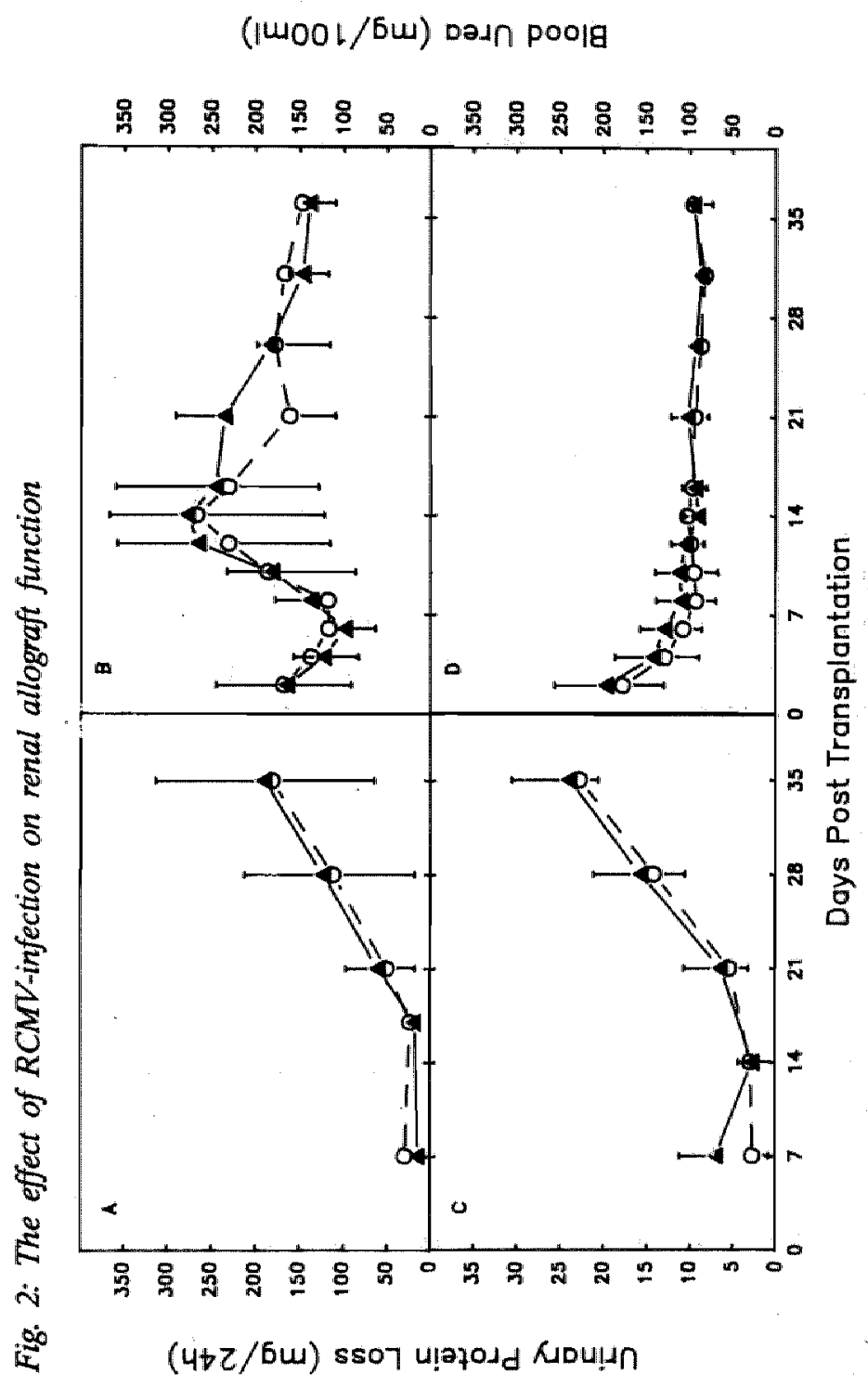

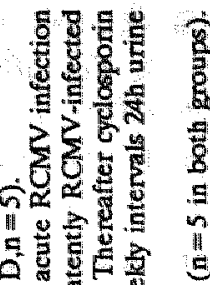

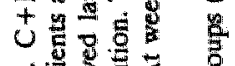

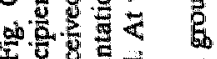

总总焉

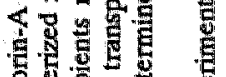

过整要

룰

古

0 远

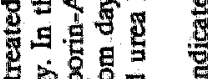

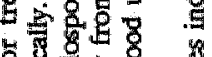

을

婙

들돌

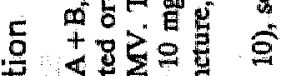

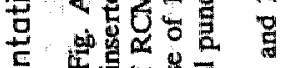

造岁可 i

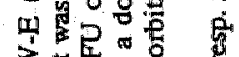

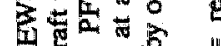

踏量

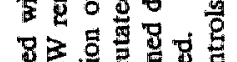

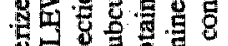

的写居

话焉

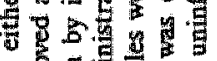

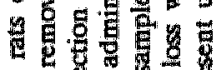

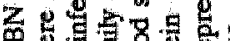

\% 8

응

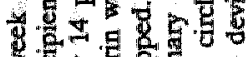

列

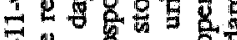

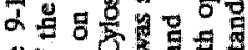
"8

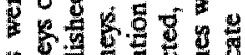

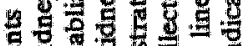
S.

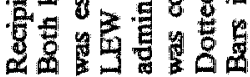


Although the models used in this study are not completely comparable to the clinical situation, where corticosteroids are invariably used in conjunction with either azathioprine or cyclosporin medication, the dose of cyclosporin used in this study is comparable tot that used in man. Corticosteroids were not used in this study since rats, compared to man, are extremely steroid sensitive (32), frequently leading to lethal superinfections (unpublished data). These, results, showing that an acute or chronic RCMV infection do not influence renal allograft function or rejection, are supported by the observation that RCMV antigens cannot be demonstrated in the renal parenchymal or vascular cells during an acute or chronic RCMV infection immunohistochemically, using monoclonal or polyclonal antibodies; in these kidneys RCMV antigens are only seen in occasional mononuclear cells (passenger leucocytes) residing in glomerular or intertubular capillaries. Endothelial cells can, however, readily be infected with CMV in vitro (33-34). Possibly chronic or acute reactivation infections in vivo might alter endothelial cells of the donor kidney by influencing $\mathrm{MHC}$ expression, e.g. by induction of higher densities of preexisting MHC antigens, or by altered antigeneic specificity either by expression of MHC antigens in conjunction with viral antigens, or by alteration of MHC expression as a result of incorporation of viral DNA into the cell genome (16,17). This might enhance cellular (and/or humoral) cytotoxic responses of the recipient towards the infected allogeneic kidney. The present data however do not support such a mechanism. Latently infected Lew kidneys residing in tolerized BN-recipients were not accelerated rejected after reactivation of the RCMV infection and in the presence of antibodies to RCMV, although these tolerized $\mathrm{BN}$ rats have normal cytotoxic $T$-cell responses to class $\mathrm{I}$ antigens $(28,29)$. In addition these kidneys were negative for RCMV antigens immunohistochemically at the time of sacrifice of the recipients.

Although $B N$ recipients of latently infected Lew kidneys treated with cyclosporin-A for three weeks show 60\% reactivation of RCMV 3 weeks post operatively as evidenced by RCMV-positive plaque assays of recipients salivary glands, in the absence of RCMV antibodies (25), the latently infected Lew kidneys in the cyclosporin-A treated $B N$ rats showed identical renal function and histology at the time of sacrifice compared to noninfected controls (Fig. 2). So, if RCMV reactivation had occurred, it did not influence allograft function. In the rat, therefore, acute RCMV infections and reactivation of latent RCMV residing in grafted kidneys do not influence acute or chronic rejection in terms of renal function or graft histology.

Some investigators have shown statistical evidence that suggest a prolonged renal allograft survival in association with active HCMV infections (18), an effect that might be explained by the well known immunosuppressive effects 
of CMV on as well humoral (35-36) as on cellular immune responses (35-36). Although the rat models used in this study were not designed to study long term graft survival, the results suggest however that acute primary or reactivation-infections do not influence acute or chronic rejection in favourable aspect either (Fig. 1 and 2).

Whether or not these findings in the rat can be extrapolated to clinical situations in man is uncertain, but since RCMV shares many characteristics with HCMV in immunobiologic aspects $(21-23,25,26,30)$ it is tempting to draw this paralell. There remain however many variables to be tested in the rat model, e.g. the effect of secondary RCMV infections on renal allograft survival, before more thorough conclusions can be drawn.

\section{ACKNOWLEDGEMENTS}

The authors wish to thank Mrs. Jeanette Cornelissen for performing kidney transplantations, Mr. Olav J.F. Schreurs for doing the creatinin and protein determinations, Mr. Henk van Rie for his assistance in the immunohistochemical analysis and Mrs. Fia Claus-Hahn, Mrs. Ilse Gronenschild and Mrs. Lilian Kreusch for their secretarial assistance. This study was supported by grant no. C83-399 from the Dutch Kidney Foundation (NSN). 


\section{REPERENCES}

1. 5.C. Marker, R. Howard, R.L. Simmons, J.M. Kalis, D.P. Conelly, J.S. Najarian, H.H. Balfowr Jr. Cytomegalowirus infection: A quantitative prospective study of 320 consecutive renal transplants. Surgery 1981; 89: 660.

2. R.P. Pass, W.K. Long, RJ. Whitley, S. Soong, A. Diethelm, D.W. Reynolds, C.A. Alford Ir. Productive infection with CMV and HSV in renal transplant recipients: role of source of kidney. $J$ inf. Dis 1978; 137: 556.

3. R.H. Rubin, A.B. Cosimi, M.S. Hirsch, J.T. Herrin, P.S. Russell, N.E. Tolkoff-Rubin. Effects of Antithymocyte globulin on CMV infection in renal transplant recipients. Transplantation 1981; 31: 143.

4. S. Naraqi, G.G. Jackson, O. Jonasson, H.J. Yamashiroya. Prospective study of prevallence, incidence and source of Herpesvirus infections in patients with renal allografts. $J$ Inf Dis: 1977; 136: 531 .

S. P.K. Peterson, H.H. Balfour, S.C. Marker, D.S. Fryd, R.J. Howard, R.L. Simmons. Cytomegallovirus disease in renal allograft recipients: A prospective study of the clinical features, risk. factors and impact on renal transplantation. Medicine 1980; 59: 283.

6. A.J. Matas, R.L. Simmons, D. Fryd, J.S. Najarian. Persistent, recurrent and late CMV infection. Transplant Proc 1981; 13: 114.

7. RM. Condie, R.J. O'Reilly. Prevention of CMV infection in bone marrow transplant recipients by prophylaxis with an intraveneous, hyperimmune CMW globulin. Birth Defects: Original Article Series 1984; 20: 327. Editors: S.A. Plotkin, S. Michelson, J.S. Pagano, F. Rapp. March of Dimes, Birth defects Foundation.

8. A.G. May, R.F. Betts, R.B. Freeman, C.H. Andrus. An analysis of CMV infection and HLA antigen matching on the outcome of renal transplantation. Ann Surg 1978; 187: 110.

9. C. Lopez, R.L. Simmons, S.M. Maurer, J.S. Najarian, RA. Goad. Association of renal allograft rejection with virus infections. Am J Med 1974; 56: 280.

10. R. Cappel, O. Hestermans, L. Toussaint, P. Verstraete, D. van Beers, J. de Braekeler, E. Schoutens. Cytomegalovirus infection and graft survival in renal graft recipients. Arch Virol 1978; 56: 149.

11. S. Naraqi, O. Jonasson, G.G. Jackson, H.M. Yamashirora. Clinical manifestations of infections with herpes viruses after kidney transplantation: A prospective study of various syndromes. Ann Surg 1978; 188: 234.

12. M.B.A. Oldstone. Virus neutralisation and virus induced immune complex disease. Virus-antibody union resulting in immunoprotection or immunologic injury - two sides of the same coin. Prog Med Virol 1975; 19: 84.

13. J.E. Payne, M. Fiala, M. Spencer, S.N. Chatterjee, "T.V. Berne. Cytomegalowirus antigen-antibody complexes in biopsy specimens in renal allograft rejection. Surg Forum 1974; 25: 273.

14. W.P. Richardson, R.B. Colvin, S.H. Cheeseman, N.E. Tolkoff-Rubin, J.T. Herrin, A.B. Cosimi et al. Glomerulopathy associated with CMV viraemia in renal allografts. New Eng J Med 1981; 305: 2 .

15. W.M. Baldwin, A van Es, G.W. Valentijn, G.W. van Gemert, M.R. Daha, L.A. van Es. Increased IgM and IgM imune-complex-like material in the circulation of renal transplant recipients with primary CMV infections. Clin Exp Immunol 1980; 50: 515.

16. J.W. Schrader, B.A. Cunningham, G.M. Edellman. Functional interactions of viral and histocompatibility antigens at tumor cell surfaces. Proc Natl Acad Sci USA 1975; 72: 5066.

17. R.M. Zinkernagel. H-2 restriction of virus specific cytotoxicity across the H-2 barrier. Separate effector T-cell specificities are associated with self $\mathrm{H}-2$ and with the tolerated allogeneic H-2 in chimeras. I Exp Med 1976; 144: 933.

18. J.D. Whelchel, R.F. Pas, A.Y Diethelm, R.J. Whitley, C.A. Alford Jr. Effect of primary and recurrent $C M V$ infection on graft and patient survival after renal transplantation. Transplamtation $1979 ; 28: 443$.

19. S. Suwansirikul, N. Rao, J.N. Dowling, M. Ho. Primary and secondary CMV infection: Clinical manifestations after renal transplantation. Arch Intern Med 1977: 137: 1026.

20. J.A. Light, D.S. Burke. Association of CMV infections with increased recipient mortality following transplantation. Transplant proc 1979; 11: 79.

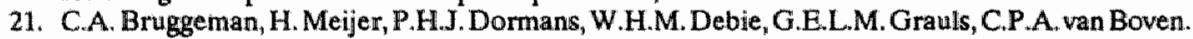
Isolation of a Cytomegalovirus-like agent from wild rats. Arch Virol 1982; $73: 231$. 
22. C.A. Bruggeman, W.H.M. Debie, G.E.L.M. Grauls, G. Majoor, C.P.A. van Boven. Infection of laboratory rats with a new cytomegallo-like virus. Arch. Virol 1983; 76: 189.

23. H. Meijer, P.H.J. Dormans, J.L.M.C. Geelen, C.P.A. van Boven. Rat Cytomegalovirus: studjes on the viral genome and proteins of virions and nucleocapsids. J Gen Virol 1984; 65: 681 .

24. J.H. Bruning, W.H.M. Debie, P.H.J. Dormans, H. Meijer, C.A. Bruggeman. The development and Characterization of Monoclonal Antibodies Against Rat Cytomegalowirus Induced Antigens. Arch. Virol. 1987, 94: 55.

25. J.H. Bruning, C.A. Bruggeman, P.J.C. van Breda-Vriesman. The Transfer of CMV infections in rats by latent infected renal allografts and the role of warious immunosuppressiwe regimens on virus replication. Transplantation (in press).

26. J.H. Bruning, C.A. Bruggeman, C.P.A. van Boven, P.J.C. van Breda Vriesman. Passive transfer of Cytomegalovirus by cardiac and renal organ transplants in a rat model. Transplantation 1986; 41: 695 .

27. P.J.C. van Breda Vriesman, L. Swanen-Sierag, L.F.M. Vlek Cytotoxic and enhancing properties of early gamma-M alloantibodies elecited by first set renal allografts. Transplantation 1975; 20: 385 .

28. G.C. Majoor, P.J.C. van Breda Vriesman. The role of antibody in trat renal allograft rejection II. Failure to enhance renal allografts by sensitization to donor class I antigens presented by donor erythrocytes. Transplantation 1983; 35: 121.

29. G.D. Majoor, M.J.W.H. van de Gaar, L.F.M. Vlek, P.J.C. van Breda Vriesman. The role of antibody in rat renal allograft rejection I. Absence of antibody to erythrocyte associated antigens is associated with prolonged renal allograft survival. Transplantation 1981; 31: 369.

30. C.A. Bruggeman, H. Meijer, F. Bosman, C.P.A. van Boven. Biology of RCMV infection. Intervirology 1985; $24: 1$.

31. R.T. Schooley, M.S. Hirsch, R.B. Colvin, A.B. Cosimi, N.E. Tolkoff-Rubin, R.T. McCluskey, R.L. Burton, P.S. Rusell, J.T. Herrin, F.L. Delonico, J.V. Giorgi, W. Henle, RH. Rubin. Association of herpesvirus infections with T lymphocyte-subset alteration, glomerulopathy and oppertunistic infections after renal transplantation. New Eng J Med 1982; 308: 6.

32. H.H. Claman. Corticosteroids and lymphoids. New Eng J Med 1972; 287: 388.

33. C.A. Bruggeman, W.H.M. Debie, G.E.L.M. Grauls, C.P.A. van Boven. Cytomegalovirus infection of Rat endothelial cells in vitro. Arch Virol 1986; 87: 265.

34. C.A. Bruggeman, W.H.M Debie, A.D. Muller, B. Schutte, M.C.F. van Dam-Mieras. Cytomegalovirus alters the von Willebrand Factor content in Human Endothelial Cells. Thrombosis Haemostasis 1988; $59: 264$.

35. R.H. Rubin, A.B. Cosimi, N.E. Tolkoff-Rubin, P.S. Russell, M.S. Hirsch. Infectious disease syndromes attributable to $\mathrm{CMV}$ and their significance among renal transplant recipients. Transplantation $1977 ; 24: 458$.

36. R.J. Howard, J.S. Najarin. CMV induced immune suppression I. Humoral immunity, II Cell mediatedi immunity. Clin Exp Immunol 1974; 18: $109+119$.

37. M. Ho. Role of specific cytotoxic lymphocytes in cellular imunity against murine CMW. Infect Immun 1980; 27: 767. 



\section{CHAPTER XII}

\section{SUMMARY AND CONCLUSIONS}


The main findings of this study are summarized in the following seven points:

1. The rat cytomegalovirus resembles closely the human cytomegalovirus in biological behaviour; as in humans it seldom causes overt disease except in severely immunocompromised rats (Chapter V). Immunohistochemically the virus and its related antigens (Chapter IV) can (up to now) only be detected in the acute phase of infection. Latently infected cells are either not recognized by the monoclonal antibodies that detect virus related antigens in the acute phase of infection (Chapter $\mathrm{V}$ and VI), or the density of these "latent" antigens is so extremely low that an incidentally staining (IPA) cell is overlooked or staining is considered nonspecific.

2. In the rat, predominantly cells of mesodermal origin appear to be infected in the acute phase of infection. Furthermore, many infected cells detected in this phase of infection are considered to have phagocytic and/or antigen presenting functions (macrophages, monocytes, endothelial cells, Kupffer cells and probably polymorphonuclear cells; Chapter V). Many reports indicate that this also may apply to the human situation (Chapter II).

3. Transmission of infection via blood or its products appears to be possible only when the blood is obtained from acutely infected rats, indicating that blood borne cells are either abortively infected, or, if latently infected, home selectively to (yet undetermined) sites and do not recirculate (Chapter VIII). In man, it appears that nucleated cells in blood or blood products obtained from blood banks may transfer infection at least $20 \%$ of the time, and thus contain (infective) virus (Chapter II). Whether or not this reflects the incidence of acute reactivation infection within the blood donors is, however, a subject for further investigation. The culture of CMV from freshly obtained donor blood has, on the other hand, seldom been successful in various large epidemiological studies, indicating that the virus, if present, is in a latent form (Chapter II).

4. At least in the rat, upon infection with RCMV, kidneys become (latently) infected in $100 \%$, and with these kidneys infection can be readily transferred (Chapter VII). There are strong epidemiological indications that this is also the case in the human situation; at least $60-80 \%$ of cases in which a seronegative patient receives a renal allograft from a seropositive donor an infection (seroconversion and/or viral shedding) occurs (Chapter II).

5. The main factors that may induce reactivation of latent RCMV are immunosuppression, alloimmune responses in form of Graft versus Host reactions, and probably aspecific inflammatory reactions brought about by the transplantation procedure itself (Chapter IX). However, the transplantation procedure may also induce reactivation via its immunosuppressive effects 
as was described for the human situation (anaesthesia and muscle relaxants; Chapter II). Also in the clinical situation, e.g. with bone marrow transplantation in man, many investigators have found strong evidence that the main factors, GvH and immunosuppression, were responsible for the occurrence of active $\mathrm{CMV}$ infections (Chapter II).

6. In the rat, as in man, the immunosuppressive regimens, administered in order to avoid allograft rejection have a definite influence on the reactivation of latent RCMV, and thus in the transfer of infection via (latently infected) renal transplants (Chapter $\mathrm{X}$ ).

7. RCMV infections have no effect on acute or chronic rejection episodes and probably do not influence renal allograft survival (Chapter XI). In man, as was discussed in Chapter II, this relationship is still controversial.

The last conclusion, however, is still speculative since many variables that may have their influence on the final outcome remain to be tested.

- In the first place it remains to be determined whether reinfections with RCMV play a role in allograft survival. As was outlined by Grundy et al. (Lancet 1987; 11: 996) many clinical and experimental data indicate that interstitial CMV pneumonia is a immunopathological phenomenon, brought about by immunological (cellular?) responses to CMV infection. It might well be that there is an analogous mechanism exists in the case of renal allograft transplantation. If so, it would be necessary to induce acute reactivation infection or reinfection from an exogenous source (infected renal allograft or inoculation of infective virus) to bring about immunopathological mechanisms leading to diminished renal allograft survival.

Strong evidence for such a mechanism is rendered by the epidemiological study of Rubin et al., 1985 (Chapter II, ref. 5).

They found a positive effect on renal allograft survival with secondary CMV infections when anti lymphocyte-globulin was administered, an effect that was not seen in recipients with either primary infections (where it had an adverse effect) or with no infection. This might indicate the existence of cellular mechanisms towards the renal allograft, leading to diminished graft survival, an effect that is abolished by administration of anti-lymphocyte serum.

- Furthermore it might well be that effects of RCMV infection on renal allograft survival are only significant in the long term, while the study here presented was designed to investigate only the short term effects.

- Another variable that was not investigated is the effect of reinfection with a RCMV-strain with distinct antigenic determinants. In man, it is well 
known that HCMV has some inverted sequences that may result in four or even eight genomic isomers. These isomers have immunological differences and these differences may thus occur within a clone of one strain.

Furthermore there are many different strains of HCMV with much larger (immunological) differences between one and another than between the various isomers of one strain.

An immunological adverse effect on renal allograft survival might be effected by reinfection with a strain with only slight immunological differences as compared to the (latent) CMV of primary infection.

To investigate this possibility various immunological distinct strains of RCMV are required.

- Another variable to be investigated is the influence of donor/recipient rat strain combination or, in other words, the effect of match/mismatch of Major and Minor transplantation antigens in combination with CMV infections. In man there is much controversy over this matter (Chapter II).

- Furthermore the effect of superinfections with other microorganisms brought about by the immunosuppressive effects of CMV infection might have an effect on renal allograft function and survival, as well as patient survival. In the rat model this can also be investigated.

- Finally, the effect of origin of the renal allograft ( cadaveric versus living/related), combined with CMV infection is frequently found to be of influence on allograft survival in man, with allografts of cadaveric origin being associated with diminished graft survival (Chapter II). In the rat model employed in this study, the warm and cold ischaemia times were limited to the minimum. It might well be that manipulation of these variables would result in diminished allograft function and survival, especially when combined with (acute) RCMV-infection. This possibility certainly should be considered in further studies.

When all the variables mentioned are tested for their effects on renal allograft survival in the rat, the conclusions, despite the close resemblance to human situations, should only be extrapolated to man with great care.

However the results will yield more insight into the possible pathogenic mechanisms underlying CMV-related disease and its effects on renal allograft survival. 


\section{SAMENVATTING}

Epidemiologisch onderzoek naar het voorkomen van antilichamen tegen het cytomegalovirus in de bevolking van westerse landen heeft aangetoond dat bij $60-90 \%$ van de onderzochten deze antilichamen aanwezig zijn. Cytomegalovirus infecties komen blijkbaar wijd verbreid voor onder de normale bevolking.

Het cytomegalovirus behoort tot de groep van de Herpesvirussen en de infectie veroorzaakt door dit virus vertoont het voor deze groep van virussen kenmerkende patroon: na een primaire infectie persisteert het virus in de gastheer in een latente vorm. Door nog veelal onbegrepen (onbekende) oorzaken kan het virus vanuit de latente vorm reactiveren en een zogenoemde secundaire infectie veroorzaken.

De mechanismen die een rol spelen bij latentie en reactivatie zijn nog onvolledig begrepen, maar er zijn vele aanwijzingen dat een intact afweersysteem van de gastheer en met name het vermogen een goede specifieke afweer tegen het Cytomegalovirus op te bouwen, belangrijk zijn bij het doen ontstaan en onderhouden van latentie.

Het overgrote deel van primaire en secundaire infecties in een gezonde gastheer verlopen ongemerkt. Bij gestoorde afweer echter, kunnen ernstige en soms dodelijke infecties optreden met o.a. ontsteking van de longen en lever.

Sinds de afstotingsreactie, die optreedt na transplantatie van lichaamsvreemde weefsels en organen, effectief onderdrukt kan worden door het gebruik van immuunsuppressieve middelen, is orgaantransplantatie een mogelijke behandeling geworden bij orgaanfunctieverlies. Het woorbeeld hiervan is de niertransplantatie die door de effectieve immuunsuppressie een grote vlucht heeft genomen. Deze immunnsuppressieve middelen echter, onderdrukken niet uitsluitend de specifieke afstotingsreactie; de gehele immunologische afweer van de gastheer wordt verminderd, zo ook de afweer tegen diverse ziekteverwekkers. Het is met name in deze patiënten waar het cytomégalovirus ernstige infecties kan veroorzaken.

Primaire infecties bij ontvangers van een niertransplantaat kunnen worden overgebracht met bloedtransfusies; in de meeste gevallen echter is de donornier de bron van zowel primaire als secundaire infecties. Ook kan door de medicamenteuze onderdrukking van het immuunsysteem latent, virus aanwezig in de getransplanteerde patiënt; reactiveren, en een secundaire infectie veroorzaken. 
Primaire en secundaire cytomegalovirus infecties bij immuun-gesuppresseerde transplantatie patiënten neigen tot een ernstig, soms levensbedreigend klinisch beloop. Deze infecties zijn dan ook niet zelden de reden voor vermindering van de immunn-suppressieve therapie. Vaak ziet men in deze groep van patiënten dan ook toename van de afstotingsreacties.

De wraag is evenwel of de toename van de afstotingsreactie een direct gevolg is van de cytomegalovirus infectie of optreedt door de vermindering van de immuno-suppressieve therapie. Deze vraag heeft vele onderzoekers en klinici beziggehouden doch de gegevens verkregen door klinisch onderzoek laten een duidelijke beantwoording hiervan niet toe.

Het doel van de experimenten beschreven in dit proefschrift was met name om die relatie te bestuderen in een goed omschreven proefdiermodel.

In dit model is het mogelijk de factoren welke bij de mens van invloed kunnen zijn op het ontstaan van CMV-gerelateerde ziekte en niertransplantaatoverleving, afzonderlijk te bestuderen.

De combinatie van de beschikbaarheid van een rat cytomegalovirus dat sterk lijkt op het humaan cytomegalovirus, en een ratmodel, welke geschikt is voor de bestudering van niertransplantatie problematiek, verschafte een goede mogelijkheid de mogelijke samenhang tussen cytomegalovirus infecties en niertransplantaatoverleving te bestuderen.

De belangrijkste bevindingen en conclusies van deze studie zijn:

1. Het rat cytomegalovirus is in biologische eigenschappen in hoge mate vergelijkbaar met het humaan cytomegallovirus. Het rat cytomegalovirus veroorzaakt bij gezonde ratten zelden ziekteverschijnselen. Dit in tegenstelling tot het veel ernstiger infectie- en ziekteverloop bij immunn-gesuppresseerde dieren (Hoofdstuk II, IV en V).

2. De cellen welke worden geïnfecteerd zijn voornamelijk van mesodermale oorsprong; vaak betreffen het cellen welke een phagocyterende eigenschap bezitten, en een functie hebben in het a-specifieke immuunsysteem (Hoofdstuk IV en V).

3. Via bloedcellen blijkt de infectie alleen dán overdraagbaar wanneer deze cellen komen van een acuut geïfecteerd dier (Hoofdstuk VIII). Ook uit het immunohistochemisch onderzoek blijkt dat bloedgedragen cellen frequent geïfecteerd zijn, doch slechts in de acute fase van infectie (Hoofdstuk IV).

4. De infectie kan gemakkelijk overgedragen worden met niertransplantaten zowel van acuut als latent geinfecteerde donor ratten. Deze nieren blijken in $100 \%$ van de gevallen (latent) virus te bevatten (Hoofdstuk VII). 
5. De belangrijkste factoren welke reactivatie van latent RCMV bewerkstelligen zijn immuunsuppressie, allogene stimulatie en waarschijnlijk a-specifieke ontstekingsreacties (Hoofdstuk VII, IX en X).

6. De vorm en diepte van immuunsuppressie blijken een belangrijke factor te zijn in het tot stand komen van reactivatie van latent RCMV, en daarmee in de overdracht van infectie met een orgaantransplantaat (Hoofdstuk X). De mate waarin deze immuunsuppressie "graft versus host" reacties onderdrukt is daarbij waarschijnlijk bepalend.

7. De met het rat-model verkregen resultaten wijzen erop dat in dit model een cytomegalovirus infectie gén invloed heeft op een acuut of chronisch afstotingsproces, en daarmee van geen invloed is op de niertransplantaatoverleving.

Deze laatste conclusie echter moet als voorlopig worden beschouwd, aangezien een aantal, mogelijk van belang zijnde variabelen, niet in het onderzoek zijn betrokken.

Het in dit proefschrift beschreven onderzoek is verricht met behulp van een rat-model. Interpretatie van de resultaten naar de humane situatie dient derhalve met grote voorzichtigheid te geschieden. Wel kan echter worden opgemerkt dat een aantal klinische waarnemingen met de getrokken conclusies in overeenstemming lijken te zijn. Verder zijn niet alle mogelijkheden die het rat-model biedt, ten volle onderzocht. In dit licht dient met name de laatste conclusie beschouwd te worden. 



\section{CURRICULUM VITAE}

De schrijver van dit proefschrift werd op 21 augustus 1954 geboren te Rantau Prapat, Indonesië. Na het behalen van het diploma HBS-a werd van 1972 tot 1976 een opleiding tropische landbouw gevolgd aan de Rijks Hogere Landbouwschool te Deventer. Na het vervullen van de militaire dienstplicht werd in 1978 aangevangen met de studie Geneeskunde aan de Rijksuniversiteit Limburg. In december 1983 werd de artsenbul uitgereikt.

Van januari 1984 tot heden was hij werkzaam bij de vakgroep Medische Microbiologie (Prof. Dr. C.P.A. van Boven) aan de Rijksuniversiteit Limburg, waar onder leiding van Dr. C.A. Bruggeman, in samenwerking met de vakgroep Immunologie (Prof. Dr. P.J.C. van Breda Vriesman), het promotie-onderzoek werd uitgevoerd dat geleid heeft tot deze dissertatie. 
Errata, behorende bij proefschrift J.H. Bruning

Pag II-18

Table IX moet zijn: VII

Pag II-23 Table VIII Ref. 48 in Legenda moet zijn: 49

Pag III-39 1e regel "An infectious virus-like agent was isolated from one of ten ..." moet zijn: "eight of ten"

Pag III-44 Legenda Fig. 5 ontbreekt

- virustitres

O cellular immunity

$\Delta$ humoral immunity

Pag V-74

Fig. 1
$A=$ plaque assay

$\mathrm{B}=$ co-cultivation

Fig. 2
$A=$ unmodified rats
$\mathrm{B}=\mathrm{x}$-irradiated rats

Pag VIII-110 Table II legenda kop "organs tested for the presence of virus" ontbreekt:

SPLEEN PEC S.G. 